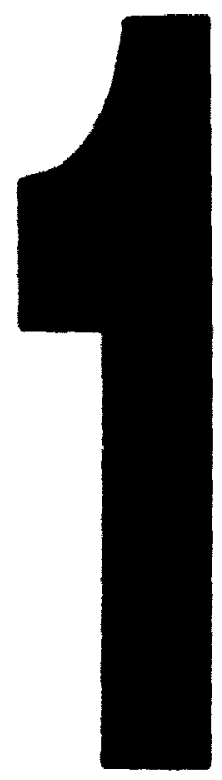

PM-1 3\%"x4" PHOTOCAAF;ic uncRocopy tancst whe wou Antriso we ECUNALET

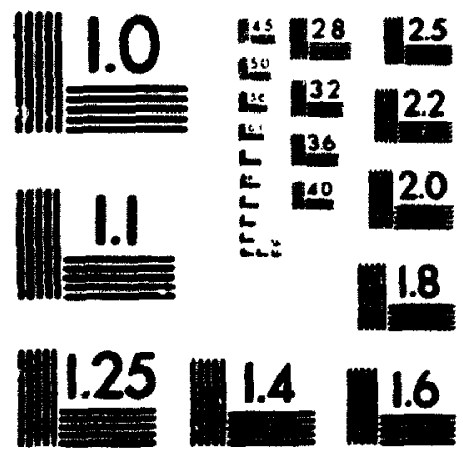

PnECHON" REsoumon TAROETs 
National Librany

of Canada

Acquisitions and

Bibliographic Services Branch

305 Wemporon Slveet

Onine. Orituro

KiAONi
Bibliotheque nationale

du Canada

Direction des acquisitions et

des services bibliographiques

395. ne Wellingtion

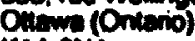

ria on
NOTICE row the votro renerence

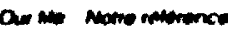

AVIS

The quality of this microform is heavily dependent upon the quality of the original theais submitted for microfilming. Every effort has been made to ensure the highest quality of reproduction possible.

If pages are missing, contact the university which granted the degree.

Some pages may have indistinct print especially if the original pages were typed with a poor typewritter ribbon or if the university sent us an inferior photocopy.
La qualité de cette microforme dépend grandement de la qualité de la these soumise au microfilmage. Nous avons tout fait pour assurer une qualité supérieure de reproduction.

S'il manque des pages, veuillez communiquer avec l'université qui a confóré le grade.

La qualité d'impression de certaines pages peut laisser à desirer, surtout si les pages originales ont été dactylographiées à l'aide d'un ruban use ou si l'université nous a falt parvenir une photocopie de qualite inferieure.

La reproduction, même partielle, de cette microforme est soumise a la Loi canadienne aur le droil d'auteur, SRC 1970, c. C-30, et ses amendements subséquents.
Reproduction in full or in part of this microform is governed by the Canadian Copyright Act,

R.S.C. 1970, C. C-30, and subsequent amendments. 


\title{
International R \& D Spillovers Between Canadian and Japanese Industries
}

\author{
hy
}

\section{Xiaoyi Yan B.A., M.A.}

\author{
A thesis submitted to \\ the Faculty of Graduate Studies and Research \\ in partial fulfilment of \\ the requirements for the degree of \\ Doctor of Philosophy \\ Department of Economics
}

\author{
Carleton University \\ Ottawa. Canada
}

(1) 1995, Xiauyi Yan 
Acquisitions and Bibliographic Services Branch du Canada

Direction des acquisitions et des services bibliographiques

395 Wellington Street Outewe Ontario

395, ne Wellington

KIAONA

THE AUTHOR HAS GRANTED AN IRREVOCABLE NON-EXCLUSIVE LICENCE ALLOWING THE NATIONAL LIBRARY OF CANADA TO REPRODUCE, LOAN, DISTRIBUTE OR SELLL COPIES OF HIS/HER THESIS BY ANY MEANS AND IN ANY FORM OR FORMAT, MAKING THIS THESIS AVAILABLE TO INTERESTED PERSONS.
L'AUTEUR A ACCORDE UNE LICENCE IRREVOCABLE ET NON EXCLUSIVE PERMETTANT A LA BIBLIOTHEQUE NATIONALE DU CANADA DE REPRODUIRE, PRETER, DISTRIBUER OU VENDRE DES COPIES DE SA THESE DE QUELQUE MANIERE ET SOUS QUELQUE FORME QUE CE SOIT POUR METTRE DES EXEMPLAIRES DF CETTE THESE A LA DISPOSITION DES PERSONNE INTERESSEES.
THE AUTHOR RETAINS OWNERSHIP OF THE COPYRIGHT IN HIS/HER THESIS. NEITHER THE THESIS NOR SUBSTANTIAL EXTRACTS FROM IT MAY BE PRINTED OR OTHERWISE REPRODUCED WITHOUT HIS/HER PERMISSION.
L'AUTEUR CONSERVE LA PROPRIETE DU DROIT D'AUTEUR QUI PROTEGE SA THESE. NI LA THESE NI DES EXTRAITS SUBSTANTIELS DE CELLECI NE DOIVENT ETRE IMPRIMES OU AUTREMENT REPRODUITS SANS SON AUTORISATION. 
Nome $X$ IAOY, YAN

Dissertation Abstracts Infernational is arranged by broad, generol subject categories. Please select the one subject which most nearly describes the content of your dissertation. Enter the corresponding four-digit code in the spaces provided.

Economics

\section{Subioct Cotogories}

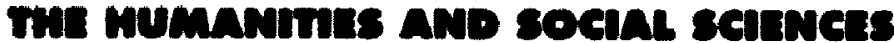

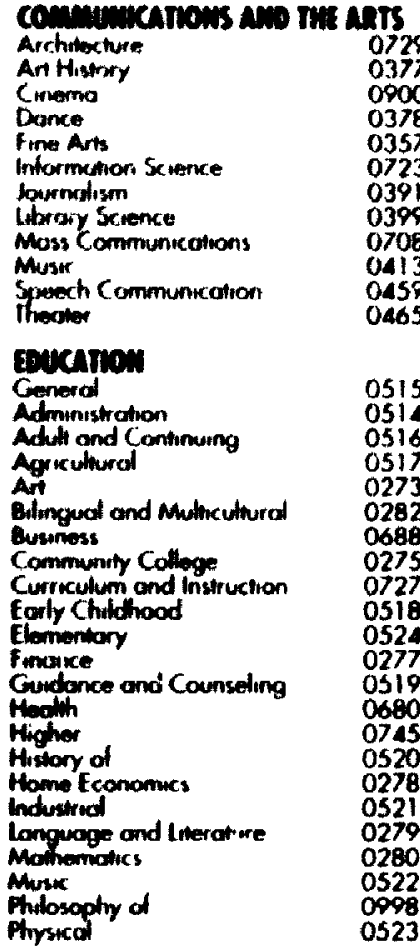

Psychology 0525

Reoding 0535

Religrous 0527

Secondary 0533

Sociol Sciences $\quad 0534$

Soxiology of $\quad 0340$

Spexiot 0529

Teocher Training $\quad 0530$

$\begin{array}{ll}\text { Technology } & 0710 \\ \text { Tests ond heasurements } & 0288\end{array}$

Vocational 0747

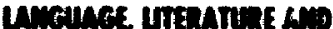
Limeustics

Language

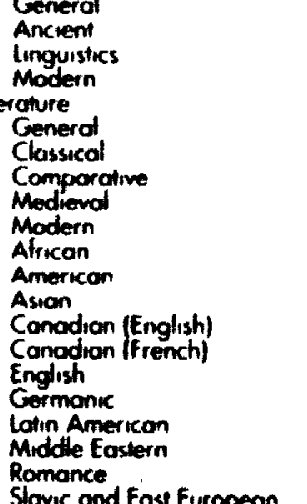

0679

0289

0290

0401

0294

0295

0298

0316

0591

0305

0593

0593

0312

0315

0313

Stavic and East Europeon

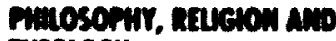

mizolosy

Philosophy

Relugion

Eeneral

Biblical Studies

Clergy

Pistory of

Theology

\section{soan sagins}

Americon Studies

Anthropoingy

$$
\text { Culturd }
$$

Phrsicol

Business Administrotion

Generd

Accouning

Bonking

Monogement

Maiketing

Conodion Studies

Economics

Aerier of

Commerce Business

Finonce

History

Labor

Folktore

Geography

Gerontology

History

General
0422

0318

0321

0319

0320

0322
0469

0323

0324

0326

0327

0310

0272

0454

0338

0338
0385

0501

0503

0505

0509

0510

0511

0358

0366
0351

0578

\section{The seninces ano Enoununume}

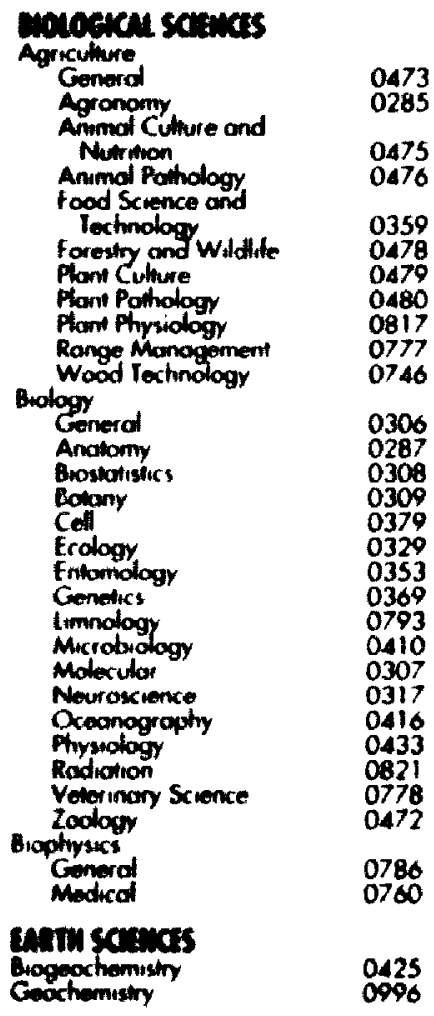

$\begin{array}{ll}\text { Geodesy } & 0370 \\ \text { Geology } & 0372 \\ \text { Geophysics } & 0373 \\ \text { Hydrology } & 0388 \\ \text { Minerology } & 0411 \\ \text { Poleobolony } & 0345 \\ \text { Poleoecology } & 0426 \\ \text { Paloonfology } & 0419 \\ \text { Paleozoology } & 0985 \\ \text { Polynologgy } & 0427 \\ \text { Physicol Geography } & 0368 \\ \text { Physical Ocooncogrophy } & 0415\end{array}$

$\begin{array}{cc}\text { Speech Pothology } & 0460 \\ \text { Toxicology } & 0383 \\ \text { Home Economics } & 0386\end{array}$

\section{Putsicu sarucs}

Pure Sciences

Chemistry

Agricultural

Analyicol

Biochemistry

inorgonis

Nuchoor

Phormoceuticol

\section{satices}

Environmental Scrences $\quad 0768$

Heolth Sciences

Audiology

Dentistrerapy

Educotion

Hospitot Manogement

Muman Dewelopment

immunology

Modicine ond Surgery 0564

Mentoi Heolth 0347

Nursing $\quad 0569$

Nutrition 0570

Obstetric and Gynecology 0380

Occupothonal thealith ond

Ophitholnology

Pothatogr

Phormocologr

Phormacy

Physed therapy

Public thoolth

Recrection
0354

0381

0571

0419

0572

0382

0573

0575
Physical

Polymer

Mathematics

Physics

General

Acoustics

Astronomy and

Astrophysics

Amospheric Science

Atomic

Electronics ond Eloctricity

Elementory Porticles ond

High Energy

Flund and Plosmo

Molocular

Nucleor

Optics.

Rodudition

Stonstics

Applind Sciones:

Applind Mochonics

Computer Science

\begin{tabular}{|c|c|}
\hline $\begin{array}{l}\text { Ancient } \\
\text { Medievol } \\
\text { Modern } \\
\text { Block } \\
\text { African } \\
\text { Asio, Austrotio and Oceon } \\
\text { Canodion } \\
\text { Europeon } \\
\text { Lolin American } \\
\text { Middle Eastern } \\
\text { Uniled Staves } \\
\text { tory of Science }\end{array}$ & $\begin{array}{l}0579 \\
0581 \\
0582 \\
0328 \\
0331 \\
0332 \\
0334 \\
0335 \\
0336 \\
0333 \\
0337 \\
0585 \\
0398\end{array}$ \\
\hline $\begin{array}{l}\text { Science } \\
\text { od } \\
\text { nohond Low and } \\
\text { otions } \\
\text { c Administrotion } \\
\text { on } \\
\text { ork }\end{array}$ & $\begin{array}{l}0616 \\
0617 \\
0814 \\
0452\end{array}$ \\
\hline $\begin{array}{l}\text { ol } \\
\text { ology and Penoiogy } \\
\text { and Rocial Studies }\end{array}$ & $\begin{array}{l}0626 \\
0627 \\
0938 \\
0631\end{array}$ \\
\hline & 0628 \\
\hline Is Social Wellore & $\begin{array}{l}0620 \\
0630\end{array}$ \\
\hline $\begin{array}{l}\text { Ment } \\
\text { Methods } \\
\text { iond Plonning }\end{array}$ & $\begin{array}{l}034 \\
0709 \\
0999\end{array}$ \\
\hline
\end{tabular}

Engineering

Generd 053

Aerospace

Automolive 0540

Biomedical C54

Chemical 056

Civil . 0543

Electronics and Electicel OS4

Heot and Thermodynomics 0348

Hydraulic

industriol

Marine

Moterials Scrence

Mechonical

Metollurgy .

Mining

suclear

Petroleum

Sonitory and Municed "O55

System Science , , . 079

Geotectunologr $\quad 042$

Operations Reyeorch ' ' 9796

Textile Technology , , , 099

pryciolosy

Generd

Behovioral

Clinical

Dovelopmental

Experimentol

industric

Personaliny

irysiologica

Punchobiology

Sociol 
The undersigned hereby recommend to

the Faculty of Graduate Studies and Research

acceptance of the thesis

"INTERNATIONAL R\&D SPILLOVERS BETWEEN CANADIAN

AND JAPANESE INDUSTRIES"

submitted by

Xiaoyi Yan, B.A., M.A.

in partial fulfilment of the requirements

for the degree of Doctor of Philosophy

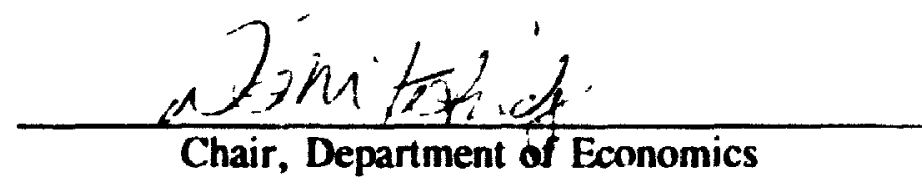

$\frac{1}{\text { Thesis Supervisor }}$

External Examiner

Carleton University 
Ti) my purents, Mr. Yan, Jiaguang and Mrs. Feng. Huiming 就给我的父母严加光先生和冯患明女士 


\begin{abstract}
AHSTRACT
This thesis estimales the effects of intramational (or donkestic) and mlemaltional (or foreign) R \& D spillovers on the cost and production siructure for tenl ('andidian and Japanese manufacturing industries. We find that intranational spillovers gencrate relatively greater effects on average variable cost and factor intensities of inulh countries. compared to international spillovers. We estimate that only three Canidian industries: electrical products. food and heverage and primary metals are affected by $R \& D$ spillovers from Japan. International spillovers from Canada affect all llke Japanese industries except chemical products. twi the effects are generally small.

Total factor pioductivity (TFP) growth is measured and dec:unpused for each industry. We find that domestic: spillovers generally commibule more than foneign spillovers to productivity gains in hoth countries. For Canada. this is the result of W.S. spillovers which increase Canadian R \& D capital so that the Canadian domestic spillover pool is enlarged and its effect outweighs the spillover effect from Japan. I,astly, we calculate the private and social rates of return to $R \& D$ for each industry and find that the social rate of return is one and one-half to twelve tinkes that of the privalce return across Canadian and Japanese industries. Moreover. the Canadian sxial ratc of return is generally two to three times higher than the Japanese equivalent. In botlı countries, the wedge between social and private retums arises in:marily from domestic ypilkovers in Canada and Japan.
\end{abstract}




\section{Acknowledgement}

I would like to thank Professor Jeffrey I. Bernstein. my thesis supervisor. Without his instructive supervision. I would not have undertaken to complete this thesis. I am graleful for his helpful comments throughout the course of this thesis. I am thankful for his patience and persistence in assisting me to accomplish the otherwise impossible.

I would like to thank Professor Brian Erard and Andre Plourde for their critical and constructive comments on the earlier drafts of this thesis. I am thankful for their generous help. Their knowledge and their work, like those of Professor Bernstein's. hav set the standard for a young economist.

I would also like to thank Professor Don McFetridge and three Ph.D. Supervisors, Professor Steven Ferris. Michel Demers and Keith Acheson, for their encouragement. My thanks also go to Professor Pierre Mohnen, my external examiner. I extend my thanks to all supporting staff in the Department of Economics.

Lastly, I am grateful to my husband and my son who have given up so much in years, and to my family whose encouragement and support I can not do without. I dedicate this thesis to my dear parents. 


\section{Table of Contents}

Bise

Chapter 1 Introduction

References 5

Chapter 2 Survey of Empirical Literature on R kD Spillovers

2.1 Introduction

2.2 Measurement of R \& D Capital and Spillovers

2.3 Modelling approaches and Empirical Findings II

2.4 Measurement of Intemational R \& D Spillovers 2.3

$\begin{array}{ll}\text { References } & 27\end{array}$

Chapter 3 The Model 31

3.1 Introduction 31

3.2 Theoretical Framework $\quad 32$

3.3 Empirical Specification

$\begin{array}{lll}3.4 & \text { Identification } & 37\end{array}$

References

$\begin{array}{lll}\text { Chapter } 4 \text { Data } & 41\end{array}$

4.1 Introduction 41

4.2 Sample 41

$\begin{array}{lll}4.3 & \text { Purchasing Power Parity } & 47\end{array}$

References

Chapter $5 \quad$ Estimation Results and Spillover Elasticities

$\begin{array}{lll}5.1 & \text { Introduction } & 63\end{array}$

5.2 Model Estimation, the Degree of Returns to Scale and the

5.3 Spillover Elasticities

$\begin{array}{lll}5.4 & \text { Summary } & 93\end{array}$

References I $\quad$ I $(9)$ 


\section{Table of Contents}

Page

Chapter 6 Total Factor Productivity Growth and Social Rates of Return 110

6.1 Intrexduction 110

6.2 Decomposition of Jotal Factor Productivity Growth 111

6.3 Social Rates of Return to R \& D

6.4 Summary of the Findings on TFPG and Social Returns 137

References $\quad 142$

Chapter $7 \quad$ Summary and Conclusion $\quad 144$ 


\section{List of Tibles}

Tille

Bille:

Table 2.1 List of Spilkover Studies

Table 2.2 Social \& Private Rates of Return in Selected Canadian Industricx 2

Table 2.3 Social \& Private Rates of Return in Selected 11.S. Industries 22

Table 4.1 Canadian and Japanese SIC of the Sampled Inclustries

Table 4.2 Statistical Description of Data: Chemical Products

Table 4.3 Statistical Description of Dala: Electrical Products

Table 4.4 Statistical Description of Data: Food and Beverage S1)

Table 4.5 Statistical Description of Data: Fabricated Metals 51

Table 4.6 Statistical Descrimicon of Data: Non-clectrical Maxhinery $\quad 52$

Table 4.7 Statistical Description of Data: Non-metallic Mineral Proxducts $\quad 5.3$

Table 4.8 Statistical Description of Data: Paper \& Allied Products $\$ 4$

Table 4.9 Statistical Description of Data:Petroleum Products 55

Table 4.10 Statistical Description of Data: Primary Metals 56

Table 4.1I Statistical Description of Data: Transportation Equipment 57

Table 4.12 The Japanese Price Index Transformed by the Purchasing Power Parity Index at 1985 (Canadian Price=1.(MX)

Table 5.1 Log of Likelihood Function Values 6.5

Table 5.2 Likelihood Ratio Test of Degree of Returns to Scale 67

Table 5.3 Likelihood Ratio Test of No Spillover Effoct

Table 5.4 Spiliover Elasticities: Chemical Products Industry 74

Table 5.5 Spillover Elasticities: Electrical Products Industry 77

Table 5.6 Spillover Elasticities: Food \& Beverage Industry 79

Table 5.7 Spillover Elasticities: Fabricated Metals Industry 81

Table 5.8 Spillover Elasticities: Non-electrical Machinery Industry $\quad$ \$3

Table 5.9 Spillover Elasticities: Non-metallic Mineral Products Industry 85

Table 5.10 Spillover Elasticities: Paper \& Allied Products Industry 87

Table 5.11 Spillover Elasticities: Petroleum Products Industry 89 


\section{List of Tables}

Tille

Table 5.12 Spillover Elasticities: Primary Metals Industry 91

Table 5.13 Spillover Elasticities: Transpontation Equipment Industry

Tahle 6.1 Decomposition of Average Annual TFP Growth Rates in tr: Chemical Products Industry

Table 6.2 Decomposition of Average Annual TFP Growth Rates in the Electrical Products Industry

Table 6.3 Decomposition of Average Annual TFP Growth Rates in the Food \& Beverage Industry

Table 6.4 Decomposition of Average Annual TFP Growth Rates in the Fabricated Metals Industry

Table 6.5 Decomposition of Average Annual TFP Growth Rates in the Non-electrical Machinery Industry

Table 6.6 Decomposition of Average Annual TFP Growth Rates in the Non-metallic Mineral Products Industry

Table 6.7 Decomposition of Average Annual TFP Growth Rates in the Paper \& Allied Products Industry

Table 6.8 Decomposition of Average Annual TFP Growth Rates in the Petroleum Products Industry

Table 6.9 Decomposition of Average Annual TFP Growth Rates in the Primary Metals Industry

Table 6.10 Decomposition of Average Annual TFP Growth Rates in the Transportation Equipment Industry

Table 6.11 Social Rates of Retum to R \& D in Canadian Industries 134

Table 6.12 Social Rates of Retum to R \& D in Japanese Industries 
List of Appendices

Pasco:

Appendix to Chapter 5

17

Appendix to Chapter 6

If (1)

$x$ 


\section{CHAPTHR I INTRODUCTION}

Research and development (R \& D) investment has been an important source of lechnological change and productivity growth [see Griliches (1988) and Nadiri (1993)]. R \& D ativities provide firms and individuals with new products produced by improved production processes. Thus, $R \& D$ investment improves the material well-being of a country and enhances competitiveness and productive efficiency.

$R$ \& $D$ investment is a cumulative process that has a public good characteristic. This characteristic arises because $R$ \& $D$ performing firms can not completely prevent other firms from using the knowledge obtained from the $R \& D$ investment. Thus, there are externalities or spillovers associated with R \& D capital accumulation. Indeed, these spillovers diminish the incentive of firms to invest in R \& D [see Spence (1984)], while at the same time they increase the diffusion of knowledge.

$R \& D$ spillovers are the knowledge transmitted from the $R$ \& $D$ investment of (thers. There are numerous transmission channels associated with R \& D spillovers. The knowledge of R \& D investing firms can spill over to other firms through, for example, intermediate input purchases. the hiring of scientists and engineers from other firms, using patented inventions, running joint ventures, international trade and foreign direct investment.

R \& D spillovers affect production structure by reducing production cost and changing the inpul-output ratios (or factor intensities) of production. $\mathbf{R} \& \mathbf{D}$ spillovers affect total factor productivity (TFP) growth. TFP growth results from technological change and non-constant returns to scale. $R \& D$ spillovers affect the rate of 
technological change and thereby TFP growth. In addition. spillovers create a wedge between private and social rates of returr. The distinction between the private and social return arises from the existence of spillovers. The private rate of return is the return from the performance of $R \& D$ : the social rate of return is the return from the use of $R \& D$. Hence, the social return includes the return associated with spillovers, which is cqual to the private rate of return plus the margiral benefits hestowed upon the $\mathbf{R} \& \mathbf{D}$ spillover users.

The purpose of this thesis is to investigate the effect of $R$ \& spillovers on the production structure, total factor productivity growth and social rates of return to $R \& D$. In particular, we focus on international spillovers between Canada and Japan, and also on the role of domestic spillovers in each industry.

The thesis is organized in a number of chapters. In Chapter 2, we present a survey of empirical literature on R \& D spillovers. There has been an ample amount of literature on $R \& D$ spillovers and their effects on the production structure, product demand, productivity growth and social rate; of return to R \& D. Most studies, however. centre on domestic intraindustry and interindustry spillovers. Moreover, the majority of the samples are drawn from Canadian and U.S. manufacturing industries. There have been a few studies that tackle international spillovers. However, international externalities have not been included with intranational spillovers in the same model such that their joint effect is studied and their relative importance is captured in contributing to productivity growth and social rates of retum to $\mathbf{R} \& D$. Bernstein (1994) studies intranational and international spillovers between Canadian and U.S. manufacturing 
industries. In this study, we are interested in internation $: \mathbf{R} \& \mathbf{D}$ spillovers that relate Canada to Japan. The reason for this focus has to do with the relative importance of Japan being Canada's largest trading partner second only to the U.S., though it accounts for significantly less than the U.S. in Canadian international trade.

In order to estimate the effects of intranational and international R \& D spillovers, we develop a long-run equilibrium model of factor demands in Chapter 3. Output is produced by four factors of production and technology indicators. The inputs are labour, materials (or intermediate inputs), and physical and $R \& D$ capital. The technology indicators are represented by $R \& D$ spillovers. Spillovers are two-dimensional -intranational and international. Intranational spillovers are domestic interindustry $\mathbf{R} \& \mathbf{D}$ externalities within Canada and Japan. Intermational spillovers are $\mathbf{R} \& \mathbf{D}$ externalities that cross national borders but link the same industry in Canada and Japan. In order to implement the model empirically, we specify a variable cost function. We then derive the equilibrium factor demand equations based on the cost function. These demand functions depend on factor prices, output and intranational and international spillovers.

The model is estimated by the full information maximum likelihood estimator. using the data set described in Chapter 4. The sample covers the period of 1962 - 1986 for ten manufacturing industries in Canada and Japan; namely, chemical products, electrical products, food and beverage, fabricated metals, non-electrical machinery, nonmetallic mineral products, paper and allied products, petroleum products, primary metals and transportation equipment. These industries are chosen because of their importance in the industrial structure of the relevant economies. In 1988, for example, these 
industries comprise $76 \%$ and $81 \%$ of Canadian and Japanese total manufacturing output and represent $95 \%$ and $88 \%$ of total industrial R \& D expenditures in Canada and Japan.

Chapter 5 contains the tests for the degree of returns to scale and the existence of international spillovers between Canada and Japan. We first test whether the degree of returns to scale is the same for the Canadian and Japanese industries and whether it is equal to unity. We then test whether international $R \& D$ spillovers exist hetween the two countries. Next. we lay out the formulae for the intranational and international spillover elasticities and discuss the estimation results of the spillover effects on average variable cost and input-output ratios (or factor intensities) of each industry.

In Chapter 6, we measure and decompose total factor productivity growth for the Canadian and Japanese industries. Total factor productivity growth is decomposed into three components: the returns to scale effect, the domestic spillover effect and the international spillover effect. In so doing, we distinguish the contribution of the two types of spiliovers to productivity growth for each of the industries in Canada and Japan. Lastly, we determine social rates of return to $R \& D$ capital and the relative importance of domestic and international spillovers to the social rates of return in the relevant industries. The social rate of return consists of the private rate of return and the returns related to the two types of spillovers. The private return is defined as the marginal cost reduction of $R \& D$ capital expansion. The retums associated with intranational and international spillovers are the cost reductions of all spillover users, domestic or foreign.

The last chapter is the summary and conclusion where we summarize our results. We conclude the thesis by discussing some policy implications drawn from the study. 


\section{REFERENCES}

Bernstein, J.I. (1994), "R \& D Spillovers Between U.S. and Canadian Industries", Forthcoming Canadiun Joumal of Economics, Papers and Proceedings.

(iriliches, Z. (1988), "Productivity Puzzles and R \& D: Another Nonexplanation", Joumal of Economic Perspectives, 2, pp. 9-21.

Nadiri. M.I. (1993), "Innovations and Technological Spillovers", NBER Working Paper \#442.3.

Spence, A.M. (1984), "Cost Reduction, Competition, and Industry Performance", Econometrica, 52, pp. 101-121. 


\section{CHAPTER 2 SURVEY OF EMPIRICAL LITERATURE ON R \& D SPIII.OVERS}

\subsection{Introduction}

This chapter presents a survey of the empirical literature relating to rescarch and development (R \& D) spillovers. In particular. this chapter focuses on measurement issues, different modelling approaches, and the general findings from empirical studies.

Productivity growth provides a stimulus to economic activity and technological change generates a positive effect on productivity growth. Much of technological change arises from research and development investment or $R \& D$ capital accumulation undertaken by firms. In this sense, $R \& D$ capital formation constitutes a major source of endogenous technological change that ultimately contributes to economic growth Isee Bernstein (1994)].

An important characteristic of $R \& D$ investment is that it has a public goxd nature. Once such investment incurs in a performing firm, many other firms can make use of it freely. Thus. firms are able to free-ride on the $R$ \& $D$ capital accumulation of other firms in the economy.

Economists identify private/public commodities according to the degree to which they are rivalrous and the degree to which they are excludable. A commodity is purely rival if it has the property that its demand by one person precludes the demand by another; likewise. a purely nonrival commodity has the property that its demand by one person in no way limits the demand by another. A commodity is excludable if the owner of the commodity can prevent others from using it. A commodity can be made excludable or partially excludable by means of a legal system such as patent law or 
copyright protection. $\mathrm{R} \& \mathrm{D}$ capital is not rivalrous. This is a characteristic of a public goxxl. It is nonrivalrous hecause its use hy the investor does not limit the use by other cconomic agents. It is not excludable (at least partially). either. The investor can reson to th- legal system for the protection of the $R \& D$ capital. However. there is no way to completely prevent others from henefiting from the $R$ \& $D$ capital stock of the performer. Thus, there is the appropriability problem related to $R \& D$ capital. The returns to $R$ \& D capital can only he appropriated incompletely.

Imperfect appropriation implies that some form of externalities or spillovers axcompany $R$ \& $D$ capital accumulation. In fact, the cost of exclusion causes the existence of spillovers. For example. R \& D performers can try to keep inventions secret until they have reaped all the returns. In so doing. they incur substantial cost which may he too expensive to he economically worthwhile. Thus there are spillovers associated with R \& D capital.

Spillovers are the knowledge transmilted from $R$ \& $D$ investment as $R$ \& D capital accumulates. They are ideas borrowed from the knowledge of others. Firms, for example, purchase machinery and equipment from each other. With the actual movement of physical assets is the transfer of knowledge embodied in making the machinery and equipment. The knowledge is being transmitted from the seller to the buyer through purchasing activities among firms in this case. Knowledge transmission can arise through many other channels such as using patented inventions. hiring labour from other firms or running joint ventures.

It is clear that R \& D capital may benefit users through knowledge transmission 
or spillovers. When R \& D is performed leading to the intioduction of new products. new processes. or improvement of existing products or processes. not only do the performers receive a stream of future henefits, but the henefits spill over to other users in and outside the performing industry. Spillovers may cause existing product denund to change. Suppose a new product is heing introduced that competes with an existing product in the market. The demand for it may be much higher than that for the predecessor because of, for example, better quality. The producer may find it no longer profitable to continuc the production of the existing product. In this case. there is a negative externality.

There are four important features of R \& D spillovers [see Bernstein (198.))]. First. R \& D spillovers reduce the production cost of all users. For example, a new assembling process is installed in Genetal Motors as a result of $R \& D$ activities. Thus GM's per unit cost of production is reduced. Suppose Ford and Chrysler ohtain this information and adopt the new process. Their unit costs are also lowered. Nevertheless. they do not have to incur the initial designing cost. Cost reduction is an extemality for them.

Second. R \& D spillovers create factor demand bias by altering the production structure in terms of factor demand requirements. Suppose the adoption of the new process in the previous example requires (V. Ford and Chrysler to demand proportionately more capital than labour. Production in these firms is now more capitalintensive than prior to the use of the patent. Hence, spillovers cause biasing effects on factor use. 
A third important feature is that $\mathbf{R} \& \mathbf{D}$ spillovers can lead to either product demand creation or demand erosion. Spillovers give rise to product quality improvement or the introduction of new products. Demand for these products increases and markets expand. However, demand may fall and markets may become smaller for other products that are substitutes. To the extent that product prices can be affected in both directions, profitability due to spillovers may be positive or negative. For example, synthetic fibre coming out of cherrinal laboratories affects the market for cotton textiles. The demand for cotton may be lower, prices may fall and profitability may ciecrease as a result. On the other hanci. demand and prices may work in favour of synthetic fibre producers in terms of profitability.

A last feature to note is that spillovers affect the demand for $R \& D$ capital. Spillovers erode the appropriability of $R \& D$ investment. Thus, firms may have less incentive to undertake their own investment in $\mathbf{R} \& \mathrm{D}$. They would rather let others do it and wait to benefit from spillovers. Consequently, their demand for R \& D capital may he reduced [Spence (1984). Dasgupta (1980) and Stiglitz (1980)]. In this case, spillovers are substitutes for own R \& D and are demand-reducing. However, R \& D extemalities may cause more R \& D capital to be accumulated. For example, in order to incorporate the knowledge borrowed from others. some form of own investment has to be undertaken [Bemstein (1988). Jaffe (1985). Rosenberg (1974) and Nelson (1982)]. In this case, spillovers are complements to own $R \& D$ and are demand-inducing.

Economists have attempted to estimate the magnitude and the extent of spillovers in order to characterize the existence and importance of $R \& D$ spillovers. A big problem 
centres on the measurement of $R \& D$ spillovers. The next section contains a discussion of alternative approaches to the measurement of $R \& D$ and the problems encountered in the existing empirical literature.

2.2 Measurement of R \& D Capital and Spillovers

R \& D spillovers originate from the product and process development assiciated with R \& D capital accumulation. Various efforts have been made to measure R \& D spillovers. Spillovers have been measured as the unweighted sum of $R \& D$ capital or R \& D expenditures. Bernstein (1988) and Bernstein and Nadiri (1988, 1989h) use the sum of R \& D capital, while Levin and Reiss (1988) define spillovers as the sum of $R$ \& $\mathrm{D}$ expenditures.

Spillovers have also been defined in terms of weighted $R \& D$ expenditures or capital. Jaffe (1986) uses the sum of all other firms' R \& D expenditure weighted by the proximity of the firms in technological space defined by patent classes. Scherer (1982. 1984), Griliches and Lichtenberg (1984), Mohnen and Lepine (1988), Mohnen (1989), using the number of patents classified by industry of origin and industry of use, consiruct a patent-based interindustry technology flow matrix as weights to the $R \& D$ expenditure of other firms. Terleckyj (1974, 1980), Wolff and Nadiri (1987) use the interindustry flows of inputs and capital goods as the weighting matrix. The weights are the proportion of one firm's purchase of intermediate inputs and capital goods from others.

An alternative measurement of R \& D spillovers is found in Bemsiein and Nadiri (1988), Bernstein (1989), and Bernstein and Nadiri (1991), where the pool of R D 
spillovers is not aggregated a priori from the R \& D capital of firms or industries to estimate their effects on profitability, production structure and productivity. Instead, the $R$ \& D capital stuck of each firm or industry is defined separately as a distinct spillover source and is estimated simultaneously with the effects of spillovers. In other words, the pool of spillovers is determined simultaneously with the estimation of the effects of spillovers.

\subsection{Modelling Approaches and Empirical Findings}

Models used to estimate the magnitude and the extent of $R$ \& $D$ spillovers are as varied as the measurement of spillovers.

In the existing studies, firms, industries or lines of business have been used for estimation. based on time series. cross-section data or panel data. The samples range from a few industries to over 600 firms, for longer or shorter periods, within a country or across national boundaries. Most samples, however, are drawn from the U.S. and Canadian manufacturing industries.

The models are structured with one or multiple equations. They include functions representing technology such as a production function or its dual cost function. Production functions are generally of a Cobb-Douglas variety. while cost functions are translog or truncated translog.

The models have been specified in terms of short-run, long-run or temporary equilibrium. The latter is based on a cost of adjustment framework. Producers incur adjusiment costs as physical and $R$ \& $D$ capital accumulates. 
The spillover variables in the models are distinguished hetween interindustry and intraindustry. In addition. the effects of spillovers are generally estimated on rales of retum, production costs. factor demand, product demand, and total facter productivity growth.

Table 2.1 lists the impor,ant studies that were done. The results are classified into four groups according to (1) spillover effects on productivity growth: (2) spillover effects on profitability and supply of output: (3) spillover effects on inpul demand: (4) sucial and privale rates of retum to $R \& D$.

(1) Spillover Effects on Productivity Growth

R \& D spillovers cause productivity gains through variable cost reduction. The important findings are the folle wing:

First. interindustry spillovers exert greater downward pressure on average cost of production relative to intra-industry spillovers. This is true for buh Canadian and U.S. industries, as found in Bemstein (1988) and Jaffe (1986).

Second, unit costs decrease more in response to an increase in the intraindustry spillovers in industries with relatively larger $R \& D$ cost shares, such as aircraft and parts, electrical products, and chemical products. However, unit costs decrease more in response to an increase in the interindustry spillovers in industries with relatively smaller $R \& D$ cost shares [Bernstein (1988)].

Third, the contribution of $R \& D$ performance within an industry (own $R \& D$ ) to total factor productivity is significa, t. However, interindustry R \& D spillovers (outside $\mathbf{R} \& D$ ) contribute more than own $R \& D$ to lotal factor productivity growth. 
Toble 2.1

Lit af Sillneret Studtex

\begin{tabular}{|c|c|c|c|c|}
\hline \multirow{2}{*}{ Study } & \multirow{2}{*}{ Sample } & \multicolumn{3}{|c|}{ Model Specification } \\
\hline & & $\begin{array}{l}\text { Technology } \\
\text { Representation }\end{array}$ & $\begin{array}{l}\text { Equations } \\
\text { Estimated \& } \\
\text { Equilibrium }\end{array}$ & $\begin{array}{l}\text { Spillover } \\
\text { Description }\end{array}$ \\
\hline $\begin{array}{l}\text { Bemstein } \\
\text { (198X) }\end{array}$ & $\begin{array}{l}680 \text { Canadian } \\
\text { firms in } 7 \\
\text { industries } \\
1978-81\end{array}$ & $\begin{array}{l}\text { Iranslog cost } \\
\text { function }\end{array}$ & $\begin{array}{l}\text { cost function, } \\
\text { labour, } \\
\text { materials. } \\
\text { physical capital } \\
\text { and } R \text { \& } D \\
\text { capital cost } \\
\text { shares } \\
\text { long-run static } \\
\text { model }\end{array}$ & $\begin{array}{l}\text { interindustry } \\
\text { and } \\
\text { intraindustry } \\
\text { effects on cost, } \\
\text { production and } \\
\text { rates of retum }\end{array}$ \\
\hline $\begin{array}{l}\text { Bermstein } \\
\text { (1989) }\end{array}$ & $\begin{array}{l}9 \text { Canadian } \\
\text { industries } \\
1963-83\end{array}$ & $\begin{array}{l}\text { truncaled } \\
\text { translor sat } \\
\text { function }\end{array}$ & $\begin{array}{l}\text { variable cost } \\
\text { function. } \\
\text { labour. } \\
\text { materials and } \\
\text { physical capital } \\
\text { cost shares } \\
\text { short-run static } \\
\text { model }\end{array}$ & $\begin{array}{l}\text { interindustry } \\
\text { effects on cost. } \\
\text { production and } \\
\text { rates of retum }\end{array}$ \\
\hline $\begin{array}{l}\text { Bernstein- } \\
\text { Nadiri } \\
\text { (1988) }\end{array}$ & $\begin{array}{l}5 \text { U.S. } \\
\text { industries } \\
|958-8|\end{array}$ & $\begin{array}{l}\text { Iranslog } \\
\text { variable cost } \\
\text { function }\end{array}$ & $\begin{array}{l}\text { variable cost } \\
\text { function. } \\
\text { labour, } \\
\text { materials and } \\
\text { physical capital } \\
\text { cost shares } \\
\text { short-run static } \\
\text { model }\end{array}$ & $\begin{array}{l}\text { interindustry } \\
\text { effects on } \\
\text { production } \\
\text { costs, factor } \\
\text { demand and } \\
\text { rates of retum }\end{array}$ \\
\hline
\end{tabular}




\begin{tabular}{|c|c|c|c|c|}
\hline \multirow{2}{*}{ Study } & \multirow{2}{*}{ Sample } & \multicolumn{3}{|c|}{ Model Specification } \\
\hline & & $\begin{array}{l}\text { Technology } \\
\text { Representation }\end{array}$ & $\begin{array}{l}\text { Equations } \\
\text { Estimated \& } \\
\text { Equilitorium }\end{array}$ & $\begin{array}{l}\text { Spillover } \\
\text { Descripticn }\end{array}$ \\
\hline $\begin{array}{l}\text { Bernstein- } \\
\text { Nadiri } \\
\text { (1989) }\end{array}$ & $\begin{array}{l}48 \text { U.S. firms } \\
\text { in } 4 \text { industries } \\
1965-78\end{array}$ & $\begin{array}{l}\text { generalized } \\
\text { quadratic } \\
\text { value function }\end{array}$ & $\begin{array}{l}\text { valuc function. } \\
\text { variable factor. } \\
\text { physical and } \\
\text { R\&D capital } \\
\text { demund } \\
\text { functions } \\
\text { temporary } \\
\text { dynamic nuxdel }\end{array}$ & $\begin{array}{l}\text { imtraindustry } \\
\text { effects on } \\
\text { variahle cosst. } \\
\text { provlection and } \\
\text { rates of return }\end{array}$ \\
\hline $\begin{array}{l}\text { Bernstein- } \\
\text { Nadiri } \\
\text { (1991) }\end{array}$ & $\begin{array}{l}6 \text { U.S. } \\
\text { industries } \\
1957-86\end{array}$ & $\begin{array}{l}\text { Iruncated } \\
\text { Iranslog } \\
\text { variable cost } \\
\text { function }\end{array}$ & $\begin{array}{l}\text { variable cost } \\
\text { function. } \\
\text { inverse product } \\
\text { demand } \\
\text { function. } \\
\text { output supply. } \\
\text { labour. } \\
\text { materials, } \\
\text { physical and } \\
\text { R\&D capital } \\
\text { cost shaures } \\
\text { temporary } \\
\text { dynamic model }\end{array}$ & $\begin{array}{l}\text { interindusiry } \\
\text { effects on } \\
\text { product } \\
\text { demuand. } \\
\text { production } \\
\text { cow's and rates } \\
\text { of returns }\end{array}$ \\
\hline $\begin{array}{l}\text { Griliches \& } \\
\text { Lichtenberg } \\
\text { (1984) }\end{array}$ & $\begin{array}{l}193 \\
\text { manufacturing } \\
\text { industries } \\
1957-78 \\
\text { subperiods }\end{array}$ & $\begin{array}{l}\text { Cobb-Douglas } \\
\text { TFP growth } \\
\text { rale }\end{array}$ & $\begin{array}{l}\text { TFP growth } \\
\text { rate equation } \\
\text { long-run static } \\
\text { model }\end{array}$ & $\begin{array}{l}\text { interindustry } \\
\text { effects on TIP } \\
\text { growth }\end{array}$ \\
\hline
\end{tabular}




\begin{tabular}{|c|c|c|c|c|}
\hline \multirow{2}{*}{ Study } & \multirow{2}{*}{ Sample } & \multicolumn{3}{|c|}{ Model Specification } \\
\hline & & $\begin{array}{l}\text { Technology } \\
\text { Representation }\end{array}$ & $\begin{array}{l}\text { Equations } \\
\text { Estimated \& } \\
\text { Equilibrium }\end{array}$ & $\begin{array}{l}\text { Spillover } \\
\text { Description }\end{array}$ \\
\hline $\begin{array}{l}\text { Jaffe } \\
\text { (1986) }\end{array}$ & $\begin{array}{l}432 \text { firms } \\
1973-79\end{array}$ & $\begin{array}{l}\text { generalized } \\
\text { Cobb-Douglas } \\
\text { knowledge } \\
\text { output } \\
\text { function }\end{array}$ & $\begin{array}{l}\text { patent } \\
\text { equation, profit } \\
\text { equation, } \\
\text { market value } \\
\text { equation } \\
\text { long-run static } \\
\text { model }\end{array}$ & $\begin{array}{l}\text { intraindustry } \\
\text { effects on } \\
\text { productivity, } \\
\text { profits and } \\
\text { market value }\end{array}$ \\
\hline $\begin{array}{l}\text { Levin-Reiss } \\
\text { (1988) }\end{array}$ & $\begin{array}{l}116 \\
\text { manufacturing } \\
\text { line of } \\
\text { business } \\
\text { (FTC) in } 1976\end{array}$ & $\begin{array}{l}\text { Cobb-Douglas } \\
\text { unit variable } \\
\text { cost function }\end{array}$ & $\begin{array}{l}\text { output supply } \\
\text { equation, } \\
\text { process R\&D } \\
\text { equation, } \\
\text { product R\&D } \\
\text { equation } \\
\text { long-run static } \\
\text { model }\end{array}$ & $\begin{array}{l}\text { interindustry } \\
\text { effects on } \\
\text { output supply, } \\
\text { process R\&D } \\
\text { intensity and } \\
\text { product R\&D } \\
\text { intensity }\end{array}$ \\
\hline $\begin{array}{l}\text { Mohnen- } \\
\text { Lepine } \\
\text { (1988) }\end{array}$ & $\begin{array}{l}12 \text { Canadian } \\
\text { industries } \\
1975.1977, \\
1979.1981-83\end{array}$ & $\begin{array}{l}\text { translog } \\
\text { variable cost } \\
\text { function }\end{array}$ & $\begin{array}{l}\text { variable cost } \\
\text { function, } \\
\text { variable inputs } \\
\text { cost share } \\
\text { equations for } \\
\text { labour, } \\
\text { materials and } \\
\text { payments for } \\
\text { technology } \\
\text { short-run static } \\
\text { model }\end{array}$ & $\begin{array}{l}\text { interindustry } \\
\text { effects on } \\
\text { demand for } \\
\text { R\&D capital } \\
\text { and production } \\
\text { cost }\end{array}$ \\
\hline
\end{tabular}




\begin{tabular}{|c|c|c|c|c|}
\hline \multirow{2}{*}{ Study } & \multirow{2}{*}{ Sample } & \multicolumn{3}{|c|}{ Model Specification } \\
\hline & & $\begin{array}{l}\text { Technology } \\
\text { Representation }\end{array}$ & $\begin{array}{l}\text { Equations } \\
\text { Estimated \& } \\
\text { Equilibrium }\end{array}$ & $\begin{array}{l}\text { Spillover } \\
\text { Description }\end{array}$ \\
\hline $\begin{array}{l}\text { Scherer } \\
(1982, \\
1984)\end{array}$ & $\begin{array}{l}87 \text { industries } \\
\text { subgroups of } \\
\text { industries } \\
1964-78 \\
\text { subperiods }\end{array}$ & $\begin{array}{l}\text { generalized } \\
\text { Cobb-Douglas } \\
\text { production } \\
\text { function }\end{array}$ & $\begin{array}{l}\text { labour } \\
\text { productivity } \\
\text { growth rate } \\
\text { equation } \\
\text { long-run static } \\
\text { model }\end{array}$ & $\begin{array}{l}\text { interindustry } \\
\text { effects on } \\
\text { productivity } \\
\text { growth }\end{array}$ \\
\hline $\begin{array}{l}\text { Sveikauskas } \\
\text { (1981) }\end{array}$ & $\begin{array}{l}144 \\
\text { manufacturing } \\
\text { industries }\end{array}$ & $\begin{array}{l}\text { generalized } \\
\text { Cobb-Douglas } \\
\text { production } \\
\text { function }\end{array}$ & $\begin{array}{l}\text { TFP growth } \\
\text { rate equation } \\
\text { long-run static } \\
\text { model }\end{array}$ & $\begin{array}{l}\text { extra-industrial } \\
\text { effects on } \\
\text { factor } \\
\text { produr:ivity } \\
\text { growth }\end{array}$ \\
\hline $\begin{array}{l}\text { Terleckyj } \\
\text { (1974) }\end{array}$ & $\begin{array}{l}20 \\
\text { manufacturing } \\
\text { and } 13 \text { non- } \\
\text { manufacturing } \\
\text { industries } \\
1948-66\end{array}$ & $\begin{array}{l}\text { generalized } \\
\text { Cobb-Douglas } \\
\text { production } \\
\text { function }\end{array}$ & $\begin{array}{l}\text { TFP growth } \\
\text { rate equation } \\
\text { short-run static } \\
\text { model }\end{array}$ & $\begin{array}{l}\text { interindusitry } \\
\text { effects on } \\
\text { productivity } \\
\text { growth and the } \\
\text { magnitude of } \\
\text { the effects }\end{array}$ \\
\hline $\begin{array}{l}\text { Terleckyj } \\
\text { (1980) }\end{array}$ & $\begin{array}{l}20 \\
\text { manufacturing } \\
\text { industries } \\
1948-66\end{array}$ & $\begin{array}{l}\text { generalized } \\
\text { Cobb-Douglas } \\
\text { production } \\
\text { function }\end{array}$ & $\begin{array}{l}\text { TFP growth } \\
\text { rate equation } \\
\text { short-run static } \\
\text { model }\end{array}$ & $\begin{array}{l}\text { interindustry } \\
\text { and } \\
\text { intraindustry } \\
\text { effects on TFP } \\
\text { growh }\end{array}$ \\
\hline
\end{tabular}




\begin{tabular}{|c|c|c|c|c|}
\hline \multirow{2}{*}{ Study } & \multirow{2}{*}{ Sample } & \multicolumn{3}{|c|}{ Model Specification } \\
\hline & & $\begin{array}{l}\text { Technology } \\
\text { Representation }\end{array}$ & $\begin{array}{l}\text { Equations } \\
\text { Estimated \& } \\
\text { Equilibrium }\end{array}$ & $\begin{array}{l}\text { Spillover } \\
\text { Description }\end{array}$ \\
\hline $\begin{array}{l}\text { Wolff- } \\
\text { Nadiri } \\
\text { (1987) }\end{array}$ & $\begin{array}{l}19 \\
\text { manufacturing } \\
\text { industries } \\
50 \\
\text { manufacturing } \\
\text { and non- } \\
\text { manufacturing } \\
\text { sectors } \\
1947,1958, \\
1963,1967, \\
1972\end{array}$ & $\begin{array}{l}\text { Leontief } \\
\text { production } \\
\text { function }\end{array}$ & $\begin{array}{l}\text { TFP growth } \\
\text { rate equation } \\
\text { long-run static } \\
\text { model }\end{array}$ & $\begin{array}{l}\text { interindustry } \\
\text { linkage effects } \\
\text { on productivity } \\
\text { growth, } R \& D \\
\text { intensity, and } \\
\text { rate of return }\end{array}$ \\
\hline
\end{tabular}


This is found in Terleckyj (1980), Scherer (1984). Griliches and Lichtenberg (1984). Furthermore, privately financed $\lambda \& D$ is far nore significant than government-financed counterpart in contributing to productivity growth. The latter is found statistically negligible in Terleckyj (1974, 1980).

(2) Spillover Effects on Profitability and Supply of Output

The supply of output is closely connected with profitability which is, in tum. determined by production cost and product price. A recent study /Bernstein and Nadiri (1991)] shows that $R$ \& $D$ spillovers generally cause output to expand and product price to fall. R \& D spillovers generate revenue growth and thus cause the size of the product market to expand. Due to output expansion, variable costs and demand for factors increase. Jaffe (1986) estimates that the net elasticity of profits with respect to the spillover pool is about 0.1 for the firms with mean $R \& D$ expenditure, implying that, if R \& D expenditure increases by 10 percent, profits will increase by about 1 percent with about one-third of the net increase coming from the spillovers.

\section{(3) Spillover Effects on Input Demand}

R \& D spillovers affect demand for factors. Generally, demand for both labour and materials decreases in response to spillovers, while that for physical capital increases. It suggests that $\mathbf{R} \& \mathbf{D}$ spillovers are at least partial substitutes for labour and materials, but complements to physical capital. This has been found in Bemstein (1988) and Bemstein and Nadiri (1991). Bernstein (1988) has also found that physical capital is 
complementary to interindustry $R \&$ D spillovers particularly in the industries with heavy R \& D cost components [Bernstein (1988)].

Nevertheless, if spillovers cause the product market to expand, spillovers may be factor demand increasing in terms of labour and materials. In Mohnen and Lepine (1988), labour is complementary to $R \& D$ in all of the 12 industries under study. Similar results are also found in Bernstein and Nadiri (1991).

The effect on the demand for $R \& D$ capital depends on the source of spillovers. Specifically, intraindustry spillovers are R \& D substitutes for firms in industries with relatively smaller propensities to spend on $R \& D$, but are complements for industries with relatively larger $R \& D$ cost shares. The interindustry effect is generally a substitute for own R \& D in all types of industries [Bernstein (1988)]. However, Mohnen and Lepine (1988) find that own $R \& D$ and payments for foreign technology (as R \& D spillovers) are strong complements.

(4) Rates of Returns to R \& D

Due to the existence of $\mathrm{R} \& \mathrm{D}$ spillovers, there is a distinction between private and social rates of return [see Bernstein (1988)]. The private rate of return is the return from the performance of $R \& D$ activities. The social rate of retum is the return from the use of $R \& D$ activities. Thus the social rate is inclusive of spillovers. It is equal to the private rate plus the sum of marginal benefits bestowed upon rival firms within an industry (intraindustry spillovers) plus the sum of marginal benefits transmitted to all firms in other industries (interindustry spillovers). 
Studies show that social rates of retum on $R \& D$ can exceed private rates quite significantly. For industries such as non-electrical machinery. rubber and plastics. petroleum products and chemical products which are major sources of spillovers. the spillover-inclusive returns are at least twice the private returns [Bernstein (1989)]. Bernstein and Nadiri (1988) finds the social rates exceed private rates by somewhere between $10 \%$ and $1000 \%$. Scherer (1982) finds that social rates of retum are in the range of $70 \%$ to $104 \%$ for a sample of eighty-seven industries. For selected manufacturing industries in the U.S. and Canada, the estimated social rates range between $11 \% 10314 \%$. Table 2.2 and Table 2.3 provides a summary of the social and private rates of return found in various Canadian and U.S. studies respectively.

Bernstein and Nadiri (1988) also find that social rates of retum to $R \& D$ show a great deal of interindustry variation. For example, in 1981 the social rate of return is $16 \%$ in the transportation equipment industry and $130 \%$ is found in the scientific instruments industry.

Although it is often difficult to distinguish between process $R \& D$ and product R \& D expenditures, Griliches and Lichtenberg (1984) show that the social rate of retum is higher on process $R \& D$, which is between $38 \%$ to $76 \%$, than on product $R \& D$, which is between $21 \%$ to $29 \%$. Scherer (1982) also finds that social returns to process R \& D are in the range of $37 \%$ to $93 \%$, while he does not find spillovers associated with product R \& D.

Privately-financed $R$ \& $D$ has experienced higher social rates of retum between $28 \%$ to $60 \%$ than publicly-financed R \& D. In Terleckyj $(1974,1980)$ and Wolff and 
Table $\mathbf{2 . 2}$

Social \& Private Rates of Return

in Selected Canadian Industries (\%)

Rates of Retum

Bernstein Bemstein

(1988)

pri soce pri socb

$12 \quad 23$

$12 \quad 26$

2581

$51 \quad 132$

Electrical products

Food \& beverage

Gas \& oii wells

Metal fabricating

Non-electrical machinery

Petroleum products

Primary metals

Pulp and paper

Rubber \& plastics

Scientific instruments

Transportation equipment
$12 \quad 26$

$38 \quad 38$

$5 \quad 24^{c}$

$33 \quad 47$
$12 \quad 20$

$33 \quad 37$

$\begin{array}{llll}12 & 20 & 29 & 29\end{array}$

$274 \quad 314$

$\begin{array}{llll}12 & 19 & 24 & 94\end{array}$

$6 \quad 12^{c}$

$27 \quad 117$

$40 \quad 87$

$26 \quad 42$

17

51

$12 \quad 20$

$47 \quad 89$

143

157

49

75

$28 \quad 29$ 
Table $\mathbf{2 . 3}$

\section{Social a Private Rates of Return \\ in Selected U.S. Industries $(\%)$ \\ Rates of Retum}

$\begin{array}{clcc}\text { Bernstein } & \text { Bemstein } & \text { Bemstein } & \text { Bernstein } \\ \text { \& Nadiri } & \text { \& Nadiri } & \text { \& Nadiri } & \text { \& Nadiri } \\ \text { (1988) } & \text { (1989a) } & \text { (1989) } & \text { (1991) }\end{array}$

Industry

pri soct

prit soc

prit soct

prit

$\sec$

Chemical products:

$13 \quad 21$

20

$7 \quad 12$

23

45

Electrical products

$15 \quad 18$

$15 \quad 25$

Food \& beverage

9

Metal fabricating

$21 \quad 21$

Non-electrical machinery

$27 \quad 58$

16

7

Petroleum products

$7 \quad 16$

Primary metals

10

Scientific instruments

$17 \quad 111$

$7 \quad 14$

25110

Transportation

$10 \quad 11$

$15 \quad 29$

pri = private rate of retum to $R \& D$

soc = social rate of retum to $R \& D$

$a=$ net of depreciation rates of retum

$b=$ gross of depreciation rates of retum

$c=$ depending on subaggregates within the industry

$d=$ average rates of retum of 1965, 1975 and 1985 
Nadiri (1987), there are no spillovers from government-financed R \& D.

Furthermore. Bernstein (1989), Bernstein and Nadiri (1988, 1991) show that each industry has its own specific spillover pattern. Generally, every industry is influenced by spillovers, with most of them having more than one spillover source. Moreover, many industries are spillover sources for a multiple of industries. For example, the scientific instruments industry sends and receives $R$ \& $D$ externalities to and from chemical products and electrical products [Bumstein and Nadiri (1988)]. Thus, the Bernstein-Nadiri research shows that it is important to distinguish between spillover sources.

However, the social rate of retum does not solely depend on the number of industries that are spillover users. The $\mathbf{R} \& \mathbf{D}$ capital of an industry can spill over to many industries, but each recipient of spillovers may only obtain a small cost reduction. Conversely, in some cases a spillover-generating industry only influences one or two industries. but the cost reductions are substantial so that the social rate of retum far exceeds the private retum to R \& D capital. For example, in Bermstein and Nadiri (1991), the $R \& D$ capital of the scientific instruments industry affects two industries -- chemicals and electrical products, but its social rate of retum is over $85 \%$ in 1985 . The social retums of the transportation equipment industry is $35 \%$ in 1985 , even though the industry induces spillovers on fabricated metal, non-electrical machinery and scientific instruments industries. Therefore, the spillover reach does not have to be extensive for social rates of return to be high. 


\subsection{Measurement of International R \& D Spillovers}

Most studies have centred on domestic spillovers. which have heen intraindustry or interindustry. International spillovers are externalities emanating from fims and industries across national boundaries. They can also relate to intraindustry or interindustry producers. For example. R \& D capital of the U.S. chemical industry can be used in the Japanese chemical or food industries. The use by the Japanese chemical industry constitutes an international intraindustry spillover. The use by the Japanese food industry is an international interindustry extemality.

Intemational knowledge transmission occurs through many channels: international trade and investment, technology transfer. joint ventures and compulsory licensing. are just a few among them. There have been a few studies measuring and estimating the effects of internationai spillovers. One recent study [Mohnen (1990)] constructed international R \& D spillovers as the sum of the R \& D stocks in foreign countries and industries, weighted by high-tech imports from industry and country of origin expressed as percentages of total high-tech imports. This approach is similar to Mohnen's (1989) domestic measure of spillovers where weights are based on patents. Using high-lech imports for the proximity measure in the intemational technology space implicitly assumes that the more a country imports high-lech products from a foreign country, the closer are the two countries technologically and the more the buyer benefits from the seller's R \& D.

This weighting approach also assumes that a unit of high-lech import is of equal value in terms of $\mathbf{R} \& D$ externality, regardless of its country of origin. However, this 
may not be the case. For example, an import from U.S. may have a higher $R$ \& $D$ capital content than an import from Japan. Therefore, $R$ \& $D$ spillovers embodied in the same kind of imports are different. Importing more or less high-lech products from a trading partner does not necessarily imply that the two countries are technologically closer or Purther apart. Countries ane technologically linked not only through international trade. There are other forms of technological transfer, so that knowledge leakage is not only through imports. For example, multinational corporations and joint ventures can generate spillovers without purchase flows between host and foreign countries. The international mobility of scientists and engineens may be another source of $R \& D$ spillovers that are not associated with trade. For these reasons, using high-tech imports is a limited weighting measure for spillovers.

Fecher (1989), Hartwich and Ewen (1983) measured international R \& spillovers hy aggregating the $R$ \& D capital stocks of foreign countries by sectors, using as weights the domestic country's sectoral purchase of intermediate inputs from foreign sectors. The framework is similar to Terleckyj $(1974,1980)$ in a domestic context. This approach assumes that spillovers follow input purchase flows. In addition, this measure accounts only for the forward linkage spillovers. In fact, the $R \& D$ capital can spill over from downstream users to upstream suppliers as well. An example would be the automobile industry. The improvement in motor vehicles will generate technological advances in steel. glass, machine tools, electrical equipment industries.

Despite the different weighting procedures, bo'h approaches define the pool of intemational spillovers as a single variable; each national or industrial spillover source is 
aggregated into a single pool of borrowed R \& D capital. The emphasis of these studiex is to determine the effects of spillovers on productivity. profitability and the production structure of recipient producers. While they are able to depiet the international links in technology between intraindustry or interindustry producers. these approaches fail to capture the relative importance of foreign nations or industries as $R$ \& D spillover sources in affecting the domestic receiving industry's production cost and factor demand.

The approach used in this thesis is based on the Bernstein-Nadiri (1988. 1991) framework. Spillovers are distinguished as intemational and intranational. Both types if spillovers are included in the model, and their effects are joinlly estimated along with the characteristics on the structure of production. In addition, we measure and decompese productivity growth for the Canadian and Japanese industries so that we can distinguish the contribution of domestic and international spillovers. Lastly we determine the soxial rate of retum to $R$ \& D capital and the relative importance of the two sources of spillovers to the social return. 


\section{REFERENCES}

Bernstein, J.I. (1994), "R \& D Spillovers Between U.S. and Canadian Industries", Forthcoming Cunadian Jourmal of Ecomomics. Papers and Proceedings.

Bernstein, J.I. (1989). "The Structure of Canadian Industrial R \& D Spillovers and the Rates of Return to R \& D". Journal of Industrial Economics, 37(3). pp. 315-328.

Bernstein. J.I. (1988), "Costs of Production. Imtraindustry and Interindustry R \& D Spillovers: Canadian Evidence". Canadian Journal of Economics, 21(2), pp. 324 347.

Bernstein. J.I. (1985). "Research and Development, Patent and Grant and Tax Policies in Canada", in D. McFetridge (ed.), Technological Change in Canadian Industry, Vol. 3 of the collected research studies of the Royal Commission on the Economic Union and Development Prospects for Canada. Toronto: University of Toronto Press. pp. 1-41.

Berr sein. J.I. and M.I. Nadiri (1991). "Product Demand. Cost of Production. Spillovers, and the Social Rale of Return to R \& D". Working Paper No. 3625, National Bureau of Economic Research, Inc.

Bemstein J.I. and M.I. Nadiri (1989a), "Rates of Retum on Physical and R \& D Capital and Siructure of the Production Process: Cross-section and Time Series Evidence", in B. Raj (ed.). Advances in Econometrics and Modelling, London: Kluwer Academic Publishers. 
Bermstein. J.I. and M.I. Nadiri (1989b). "Reseanch and Development and Intraimlustry Spillovers: an Empirical Application of Dynamic Duality". Re'vien of Ecomemic Studies. 56. pp. 249-269.

Bernstein J.1. and M.I. Nadiri (1988). "Interindustry R \& D Spillovers. Rantes of Retum. and Production in High-Tech Industries". American Liomomic Review: May. pp. 429-434.

Dasgupts. P. (1986), "The Theory of Technological Competition". in J.E. Stiglitz. and G.F. Mathewson (eds.). New Developments in the Amalysis of Martert Structure, Cambridge: MIT Press.

Griliches, Z. (1979), "Issues in Assessing the Contribution of Research and Developmemt to Productivity Growth". Bell Joumal of Economics. 10(1). pp. 92-116.

Griliches, Z. and F. Lichtenberg (1984). "Interindustry Technology Flows and Productivity Growth: A Reexamination", Review of Ecomomics and Statistics. 66. pp. 324-329.

Jaffe, A.B. (1986). "Technological Opponunity and Spillovers of $R$ \& D: Iividence from Firms' Patents, Profits, and Market Value", American Eicomomic Review. 79(5), pp. 957-970.

Levin, R. and P. Reiss (1988), "Cost-reducing and Demand Creating R \& D with Spillovers", Rand Joumal of Ecomomics, 19(4), pp. 538-556.

Mohnen, P. (1990), "Relationship between R \& D and Productivity Growth in Canada and Orher Major Industrialized Countries". Centre de recherche sur les politiques économiques, Université du Québec à Montréal. 
Mohnen. P. (1989). "New Technologies and Interindustry Spillovers", paper presented at the OECD International Seminar on Science, Technology and Economic Growth. Paris, France, June 5-8.

Mohnen, P. and N. Lepine (1988). "Payments for Technology as a Factor of Production", Departement des sciences économiques, Université du Québec à Montréal. (ahier $\$ 8811)$.

Nelson. R.R. (1982), "The Role of Knowledge in R \& D Efficiency", Quarterly Journal of Ecomonics. 97. pp. 453-470.

Romer. P.M. (1990). "Endogenous Technological Change", Jnumal of Political Ecomomy. 98. $\$ 71-\$ 102$.

Rowenherg. N. (1974). "Science. Invention and Economic Growth", Economic Journal, 84, pp. 90-108.

Scherer. F.M. (1984). "Using Linked Patent and R \& D Data to Measure Interindustry Technology Flows", in Z. Griliches (ed.). $R$ \& D, Patents and Productivity, Chicago: University of Chicago Press. pp. 417-464.

Scherer. F.M. (1982). "Interindustry Technology Flows and Productivity Growth", Revien of Economics and Statistics, 64. pp. 627-634.

Spence. A.M. (1984). "Cost Reduction, Competition, and Industry Performance", Eicomometrica. 52. pp. $101-121$.

Stiglitz. J.E. (1980). "Industrial Structure and the Nature of Economic Activity", Ecomomic Journal. 90, pp. 266-293. 
30

Sveikauskas, L. (1981), "Technology Inputs and Multifactor Productivity Growth". Review of Ecommics and Statistics. 6.3. pp. 275-282.

Terleckyj. N. (1980). "Direct and Indirect Effects of Industrial Research and Development on the Productivity Growth of Industries", in J. Kendrick and B.Vaccara (eds.). New' Developments in Productivity Measurement and Analysis. Chicago: University of Press, Chicago. pp. 359-377.

Terleckyj. N. (1974). "Effects of R \& D on the Productivity Growth of Industries: An Explanatory Study", National Planning Association, Washington D.C.

Wolff, E.N. and M.I. Nadiri (1987), "Spillover Effects, Linkage Structure. Technical Progress. and Research and Development". C.V. Starr Centre Research Report $\# 87 / 43$. 


\section{CHAPTER 3 THE MODEL}

\section{I Introduction}

In this chapter, we set up a model of $R$ \& D spillovers in order to study the effects of spillovers on the structure of production, productivity growth and the social rates of return to R \& D [sce Bernstein (1994)]. In this production-oriented approach, R \& D capital is an additional factor of production. However, it is distinguished from other inputs as there are externalities associated with $R$ \& $D$ capital.

Since products, services, investment and knowledge flow between nations, a country's stock of knowledge depends on its own $R \& D$ investment and on the $R \& D$ efforts of other countries as well. R \& D spillovers extend beyond national borders. In this study, we are interested in intemational spillovers between Canadian and Japanese industries. Japan has been Canada's second largest trading partner next only to the U.S. In 1993 imports from Japan accounted for $6.3 \%$ of Canadian imports or $\$ 10.7$ billion. The value of imports from Japan was $\$ 5.7$ billion in 1984 and grew over the next ten years at an average rate of $6.5 \%$ per year. Exports to Japan was $5.1 \%$ of Canadian exports in 1993 or $\$ 8.4$ billion. Canadian exports to Japan increased from $\$ 5.6$ billion in 1984 and grew over the next ten years at an average annual growth rate of $4 \%$.

This chapter is organized in the following way. In Section 2, we present the theoretical model which describes the optimizing problem of production within the context of $\mathbf{R} \& D$ spiliovers. Section 3 deals with the empirical specification of the model and the last section discusses the problem of parameter identification. 


\subsection{Theoretical Framework}

Output is produced with a combination of non-capital inputs. capital inputs and R \& D spillovers. The non-capital factors are labour and materials. The capital inputs are physical and R \& D capital.

R \& D spillovers come from intranational (or domestic) sources and international (or foreign) sources. Intranational spillovers relate to interindustry $R \& D$ externalities within Canada or Japan. Intranational spillovers are measured as the stock of $\mathbf{R} \& \mathbf{D}$ capital in domestic industries other than the representative one lagged one period. For example, $R$ \& $D$ spillovers to the Canadian chemical industry emanate from stock of $R$ \& $\mathrm{D}$ in all other Canadian industries. International spillovers relate to extemalities that cross national boundaries but link the same industry in Canada and Japan. International spillovers are measured as the stock of $\mathbf{R} \& \mathbf{D}$ capital in the corresponding foreign industry lagged one period. For example, the Canadian chemical industry receives $\mathbf{R} \&$ D spillovers from the Japanese chenical industry.

Domestic intraindustry spillovers are assumed to be internalized, because the analysis is conducted at the two-digit standard industrial classification level. The interindustry R \& D spillovers between nations is also a source of externality. However. its effect is captured indirectly through the domestic industry to the corresponding industry in the foreign country. For example, with respect to chemical products, $R \& D$ spillovers of all other Japanese industries affect the Japanese chemical industry which, in turn, affects the Canadian chemical industry. Next the spillovers from the Canadian chemical industry, as a source of domestic spillovers, are extended to all other Canadian 
industries. The Japanese and Canadian chemical industries, in this case, act as carriers that link all the industries in both countries.

The technology of the industries is characterized by the following production process:

$$
y_{t}=F\left(v_{t}, K_{t}, s_{t-1}\right)
$$

where $y$ is the single output, $v$ is the two-dimensional vector of variable input demands. $K$ is the two-dimensional vector of capital input demands, $S$ is the two-dimensional vector of spillover variables and $F$ is the production function. The production function is defined for nonnegative input and output quantities with positive marginal product. The function is assumed to be twice continuously differentiable, and quasi-concave in the inputs.

The objective function is:

$$
\min _{v_{i}, x_{k}} \boldsymbol{\Sigma}_{i} w_{i t} v_{1 t}+\boldsymbol{\Sigma}_{k} \boldsymbol{\omega}_{k t} \boldsymbol{K}_{k t}
$$

where $w_{1}(i=1,2)$ is the vector of non-capital factor prices, $\omega_{k}(k=1,2)$ is the vector of capital input prices (in other words, the rental rates) of the capital inputs.

The optimization problem can be split into two stages. The first stage pertains to the determination of the variable factor or non-capital demands, while the second stage relates to the demands for the capital inputs.

In the first stage, output is given and capital stocks are fixed. The cost of variable factors are minimized. subject to the production function. Thus, the optimizing problem is: 


$$
\begin{aligned}
& \min _{v_{t}} \Sigma_{i} w_{i t} v_{1 t} \\
& \text { s.t. } y_{t}=F\left(v_{t}, K_{t}, s_{t-1}\right) .
\end{aligned}
$$

The solution to equation (3.3) is considered the short-run production equilibrium, because the capital inputs are fixed at this stage. Substituting the short-run equilibrium conditions into variable factor cost (that is $\Sigma, w_{1}$, ) yields the variable cost function:

$$
c_{t}^{v}=C^{v}\left(w_{t}, y_{t}, K_{t}, s_{t-1}\right),
$$

where $c^{v}$ is variable cost and $C^{v}$ is the variable cost function which is twice continuously differentiable, nondecreasing in $w, y$ and nonincreasing in $K$, concave and homogetieous of degree one in $w$ and convex in $K$. Applying Shepherd's Lemma $\left(\partial c^{\prime} / \partial w_{1}=v_{1}\right)$, we can retrieve the Jemands for variable factors from the variable cost function:

$$
v_{t}=\nabla_{v} C^{v}\left(w_{t}, y_{t}, K_{t}, S_{t-1}\right) .
$$

The variable factor demands depend on the non-capital factor prices, output, the capital inputs and the $R$ \& D spillovers. $R$ \& D spillovers affect variable factor demands as well as variable cost.

In the second stage, we determine the demands for capital inputs. We do this by substituting into equation (3.2) the variable cost function:

$$
\min _{k_{k}} C^{v}\left(w_{t}, y_{t}, K_{t}, S_{t-1}\right)+\Sigma_{k} w_{k t} K_{k t}
$$

We obtain the equilibrium conditions for $K_{k}$ as:

$$
-\omega_{t}=\nabla_{k} C^{v}\left(w_{t}, y_{t}, K_{t}, s_{t-1}\right) .
$$


Capital input demands depend on non-capital input prices, output. $R \& D$ spillovers and capital input prices. Equation sets (3.5) and (3.7) describe the equilibrium conditions and thereby the model that is to be estimated.

\subsection{Empirical Specification}

In order to implement the model empirically (given by equation sets (3.5) and (3.7)), we need to specify the variable cost function:

$$
\begin{aligned}
c_{t}^{v}= & \left(\sum_{i=1}^{2} \beta_{i} w_{i t}+0.5 \sum_{j=1}^{2} \sum_{j=1}^{2} \beta_{i j} w_{i t} w_{j t} w_{t}^{-1}\right) y_{t}^{0}+\left(\sum_{k=1}^{2} \varphi_{k} K_{k t}\right. \\
& \left.+0.5 \sum_{k=1}^{2} \sum_{j=1}^{2} a_{k j} K_{k t} K_{j t} / y_{t}^{0}+\sum_{k=1}^{2} \sum_{j=1}^{2} \eta_{k j} K_{k t} s_{j t-1}\right) w_{t}
\end{aligned}
$$

where $w_{t}=\sum_{i=1}^{2} \gamma_{i t} w_{i t}=\sum_{i=1}^{2}\left(w_{i 0} v_{i 0} / \sum_{i=1}^{2} w_{10} v_{i 0}\right) w_{i t}$ is a Laspeyres variable input price index $\left(\gamma_{1}=1,2\right.$ are fixed coefficients). We define $W$ in this way to avoid arbitrarily selecting one variable input price to normalize the cost function: rather the function is normalized by a weighted average of hoth prices so that we have symmetric variable factor demand equations for estimation. The parameters are represented by the $2 \times 1$ vector of $\beta_{,}$, the $2 \times 2$ matrices of $\alpha_{k i}$ and $\beta_{i j}$ the $2 \times 1$ vectors of $\varphi_{k,}$, the $2 \times 2$ matrix of $\eta_{k y}$ and the scalar $\theta$. The scale parameter is $\theta^{-1}(\theta$ is the variable cost flexibility). To see this, note that the degree of returns to scale is given by $\theta^{-1}=\left(1-\Sigma_{k} \partial \ln c_{l}^{1} / \partial \ln K_{k 1}\right) /\left(\partial \operatorname{lnc} c_{t}{ }^{1} / \partial \ln y_{1}\right)$. In this model we do not restrict the degree of returns to scale.

The variable cost function is a second order approximation by a Taylor series. The functional form is a simple extension of the one developed by Diewert and Wales (1987). The extension involves the possibility of non-constant returns to scale. The 
attractiveness of this functional form is that the concavity and convexity properties of the variable cost function can be imposed without restricting the flexibility of the form.

Let us define $k_{k t}=K_{k} / y_{1}$, we can write the variable cost function per unit of output as:

$$
\begin{aligned}
\frac{c_{t}^{v}}{y_{t}}= & \left(\sum_{i=1}^{2} \beta_{i} w_{j t}+0.5 \sum_{i=1}^{2} \sum_{j=1}^{2} \beta_{i j} w_{i t} w_{j t} w_{t}^{-1}\right) y_{t}^{\theta-1}+\left(\sum_{k=1}^{2} p_{k} k_{k t}\right. \\
& \left.+0.5 \sum_{k=1}^{2} \sum_{j=1}^{2} a_{k j} k_{k t} k_{j t} / y_{t}^{\theta-1}+\sum_{k=1}^{2} \sum_{j=1}^{2} \eta_{k j} k_{k t} s_{j t-1}\right) w_{t} .
\end{aligned}
$$

Using equation (3.9), the non-capital input demand equations (equation set (3.5)) can be written as:

$$
\begin{gathered}
v_{i t}=\left(\beta_{i}+\sum_{j=1}^{2} \beta_{i j} w_{j t} w_{t}^{-1}-0.5 \sum_{l=1}^{2} \sum_{j=1}^{2} \beta_{l j} w_{l t} w_{j t} w_{t}^{-2} \gamma_{j t}\right) y_{t}^{0-1} \\
(3.10)+\left(\sum_{k=1}^{2} \varphi_{k} k_{k t}+0.5 \sum_{k=1}^{2} \sum_{j=1}^{2} \alpha_{k j} k_{k t} k_{j t} / y_{t}^{0-1}+\sum_{k=1}^{2} \sum_{j=1}^{2} \eta_{k j} k_{k t} s_{j t-1}\right) \gamma_{f t} \\
i=1,2,
\end{gathered}
$$

where $v_{i t}=v_{i f} / y_{i}, i=1,2$. In addition, the equilibrium conditions for the capital inputs (that is equation (3.7)) can be written as:

$$
\begin{gathered}
-\left(\varphi_{k}+\sum_{j=1}^{2} a_{k j} k_{j l} / y_{i}^{0-1}+\sum_{j-1}^{2} \eta_{k j} s_{j t-1}\right) w_{l}=\omega_{k l} \\
k=1,2 .
\end{gathered}
$$

We can obtain the demands for the capital inputs by solving equation (3.11). Thus.

$$
k_{1 t}=\frac{\alpha_{22}}{\left(\alpha_{11} \alpha_{22}-\alpha_{12}^{2}\right)} A_{1 t}-\frac{\alpha_{12}}{\left(\alpha_{11} \alpha_{22}-\alpha_{12}^{2}\right)} A_{2 t}
$$




$$
k_{2 t}=\frac{-\alpha_{12}}{\left(\alpha_{11} \alpha_{22}-\alpha_{12}^{2}\right)} A_{1 t}+\frac{\alpha_{11}}{\left(\alpha_{11} \alpha_{22}-\alpha_{12}^{2}\right)} A_{2 t}
$$

where $A_{k t}=\left(-\varphi_{k}-\sum_{j=1}^{2} \eta_{k f} s_{f t-1}-\omega_{k t} w_{t}^{-1}\right) y_{t}^{0-1}, k=1,2$.

From equation sets (3.10) and (3.12) we see that the spillovers affect variable factor demands directly through the $\eta_{k j}$ parameters and indirectly through the capital demands by way of the $\alpha_{t j}$ parameters. The spillovers affect the capital input demands through the $\eta_{k j}$ and $\alpha_{k,}$ parameters.

Equation sets (3.10) and (3.12) denote the equilibrium demand conditions for the non-capital and capital inputs.

\subsection{Identification}

In order to estimate the model, the parameters in the equations must be identified. In this context, we note that in the unit variable cost function we have the term:

$$
\begin{aligned}
\Sigma_{i} \beta_{i} w_{i t}+0.5 \Sigma_{j} \Sigma_{j} \beta_{t j} w_{i} w_{j} w_{t}^{-1} & =\beta^{T_{w_{t}}}+0.5 w_{t}^{T} B w_{t}\left(\gamma^{T} w_{t}\right)^{-1} \\
& =0.5\left(\gamma^{T} w_{t}\right)^{-1} w_{t}^{T}\left(B+2 \gamma \beta^{T}\right) w_{t} .
\end{aligned}
$$

where $Y=\left[\begin{array}{l}Y_{1} \\ \gamma_{2}\end{array}\right], \quad \beta=\left[\begin{array}{l}\beta_{1} \\ \beta_{2}\end{array}\right]$ and $B=\left[\begin{array}{ll}\beta_{11} & \beta_{12} \\ \beta_{12} & \beta_{22}\end{array}\right]$.

Clearly. only the linear combination of the parameters $\left[B+2 \gamma \beta^{\top}\right]$ is identified (recall that $\gamma$ is a vector of fixed coefficients). This means that we cannot identify the $B$ and $\beta$ parameters separately. Therefore, we need to impose two restrictions on the estimation model and these restrictions are $B i=0$. where $i$ is the unit vector. Thus, $\beta_{11}+\beta_{12}=0$, 
$\beta_{12}+\beta_{22}=0$ or $\beta_{11}=-\beta_{12}=\beta_{22}$. In the estimation of the model we impose this parameter identification restriction. 


\section{REFERENCES}

Bernstein, J.I. (1994), "R \& D Spillovers Between U.S. and Canadian Industries", Forthcoming Canadian Joumal of Economics, Papers and Proceedings.

Bernstein. J.I. (1994). "Taxes, Incentives and Production: The Case of Turkey", Joumal of Development Economics. Vol. 45. pp. 55-79.

Bernstein. J.I. (1989). "The Structure of Canadian Interindustry R \& D Spillovers and the Rates of Return to R \& D", Joumal of Industrual Economics, 37(3), pp. 315 328.

Semstein. J.I. (1988). "Cosis of Production, Intraindustry and Interindustry R \& D Spillovers: Canadian Evidence". Canadian Journal of Economics, 21(2), pp. 324347.

Bernstein. J.I. and M.I. Nadiri (1991), "Product Demand, Cost of Production, Spillovers, and the Social Rate of Return to R \& D", Working Paper NO. 3625, National Bureau of Economic Research. Inc.

Bernstein. J.I. and M.I. Nadir. (1989b), "Research and Development and Intraindustry Spillovers: an Empirical Application of Dynamic Duality", Review of Economic Studies. 56. pp. 249-269.

Diewert. W.E. (1982), "Duality Approaches to Microeconomic Theory", in K. Arrow and M. Intriligator (eds). Handbook of Mathematical Economics, Vol. 2. Amsterdam: Elsevier Science Publishers, pp. 535-591.

Diewert. W.E. and T.J. Wales (1988). "A Normalized Quadratic Semiflexible Functional Form". Journal of Econometrics. 37, pp. 327-342. 
Diewert, W.E. an', T.J. Wales (1987). "Flexible Functional Fomks and Global Curvature Conditions". Econometrica, 55(1), pp. 43-68.

Epstein, L.G. (i981), "Duality Theory and Functional Forms for Dynamic Factor Demands". Review of Economic Studies. 48, pp. 81-95.

Jorgenson, D.W. (1986), "Econometric Methods for Modelling Producer Behaviour", in Z. Griliches and M. Intriligator (eds), Handbrosk of Eiomometrics, Vol. 3. Amsterdam: Elsevier Science Publishers, pp. 1841-1915.

Mohnen, P. (1990). "Relationship between R \& D and Productivity Growth in Canada and Other Major Industrialized Countries". Centre de recherche sur les politiques économiques, Université du Québec à Montréal.

Varian, H.R. Micruecomomic Analysis, 3rd Edition, W.W. Norton \& Company Inc.

Intermational Trade Statistics Yearbook (1990), Vol. I. United Nations. 


\section{CHAPTER 4 DATA}

\subsection{Introduction}

This chapter describes the data sources and defines the variables used in the estimation of the model. In particular, it presents the means and standard deviations. minima and maxima. of the variables for each of the sampled industries in each country. In addition, it discusses the issue of purchasing power parity as related to the linking of prices between countries.

\subsection{Sample}

The sample covers 10 manufacturing industries in Canada and Japan from 1962 to 1986. The industries are defined at the two-digit Canadian and Japanese Standand Ind: atrial Classification (SIC) levels respectively. The ten industries are chemical products. electrical products. food and bererage, fabricated metals, non-electrical machinery, non-metallic mineral products, paper and allied products, petroleum products, primary metals, and transpurtation equipment. The corresponding Canadian and Japanese SICs are listed in Table 4.1.

The data are annual observations on the Canadian and Japanese industries. The variables relate to quantities and prices of ouputs and inputs. There are four types of inputs: labour. materials, physical capital and $\mathbf{R} \& \mathrm{D}$ capital. There is a single output. The sample period is from 1962 to 1986.

The Canadian data are taken from the published sources of Statistics Canada. The interes rate on long-term ( 10 years and over) government bonds is taken from the Bank 
Table 4.1

\section{Canodian and Inpanese SIC for the Somplad Induatries}

\begin{tabular}{|l|l|l|}
\hline \multicolumn{1}{|c|}{ INDUSTRY } & CANADIAN SIC & JAPANESE SIC \\
\hline Chemical products & 37 & \\
\hline Eloctrical products & 33 & 26 \\
\hline Food and beverage & 10.11 .12 & 35 \\
\hline Fabricated metals & 30 & 19 \\
\hline Non-electrical machinery & 31 & 33 \\
\hline Non-metallic mineral products & 35 & 34 \\
\hline Paper and allied products & 27 & 30 \\
\hline Petroleum products & 36 & 24 \\
\hline Primary metals & 29 & 27 \\
\hline Transportatior equipment & 32 & 31.32 \\
\hline
\end{tabular}


of Canada Review. The Canadian tax data are drawn from Corporation Taxation Statistics published by Statistics Canada. The Japanese production data are obtained from the published sources of the Economic Planning Agency. The Japanese $R$ \& $D$ data are taken from the publications of the Statistics Bureau of the Prime Minister's Office in Japan. The data on Japanese interest rate and taxes are drawn from the various publications of the Institute of Economic Research, Economic Planning Agency and the Ministry of Finance in Japan.

For Canada, the variables are defined as follows. The quantity of output (YC) for each industry is the two-digit SIC gross output in millions of 1985 dollars. The price of output (PC) is an index with $1985=1.00$ and is obtained by dividing 1985 dollar gross output into current dollar gros: output. The quantity of labour (VLC) is labour compensation in millions of 1985 dollars. The price of labour (WLC) is current dollar labour compensation divided by 1985 dollar labour compensation. This price is then indexed to 1.00 in 1985 . The quantity of materials (VMC) is intermediate goods in millions of 1985 dollars measured by taking the difference between gross output in 1985 dollars and value-added in 1985 dollars. The price of materials (WMC) is obtained by taking the ratio of intermediate goods in current and 1985 dollars and indexed to 1.00 in 1985. The quantity of physical capital (VKC) is the geometric net stock in millions of 1985 dollars. The acquisition or purchase price of physical capital is the Divisia index of prices of investment for buildings and engineering construction, machinery and equipment. and other capital. This index is 1.00 in 1985 . We convert the purchase prices into before-tax rental rates on physical capital (WKC) using: 


$$
W K C=p_{k}\left(r+\delta_{k}\right)\left(1-I T C_{k}-u_{c} z\right) /\left(1-u_{c}\right) \text {. }
$$

where $p_{k}$ is the acquisition price of physical capital, $r$ is the interest rate on kong-term government bonds, $\delta_{k}$ is physical capital depreciation rate. $I T C_{k}$ is the investment tax credit rate, $u$, is the corporate income tax rate and $z$ is the present value of capital cost allowances.

The present value of capital cost allowances is calculated using the declining balance method. The sum is calculated under two regimes, distinguished by whether the half-year rule is or is not in effect. In addition, capital cost allowances are different for buildings and engineering construction and for machinery and equipment. For buildings and engineering constructions, the discounted sum of capital cost allowances, $z_{m}$, outside the half-year rule is:

$$
z_{B}=\frac{C C A_{B}\left(1+I T C_{B}\right)(1+r)}{\left(I+C C A_{B}\right)}
$$

where $C C A$ is capital cost allowances and subscript $B$ stands for building and engineering constructions. Inside the half-year rule the present value of cost allowances is:

$$
z_{B}=\frac{C C A_{B}\left(1-I T C_{B}\right)}{2}+\left(1-\frac{C C A_{B}}{2}\right) \frac{C C A_{B}\left(1-I T C_{B}\right)}{\left(I+C C A_{B}\right)}
$$

The present value of cost allowances for machinery and equipment, $z_{M}$, outside the half year rule is:

$$
z_{M}=\sum_{t=0}^{T} \frac{\operatorname{CCA}_{M}\left(1-I T C_{M}\right)}{(1+r)^{t}}
$$

where $t$ represents time, $T$ represents number of years and subscript $M$ stands for 
machinery and equip. rent. Inside the half-year rule the discounted sum is:

$$
z_{M}=\sum_{t=0}^{T-1} \frac{C C A_{M}\left(1-I T C_{M}\right)}{(1+I)}+\frac{C C A_{M}\left(1-I T C_{M}\right)}{2}\left(1+\frac{1}{(1+I)^{T}}\right)
$$

The aggregate $z$ is an index of $z_{a}$ for buildings and engineering constructions and $z_{M}$ for machinery and equipment.

$\because \&$ D capital stock (VRC) is defined by the perpetual inventory method based on millions of 1985 dollar R \& D expenditures using deflators for R \& D made available by Statistics Canada. Initial constant dollar $\mathbf{R} \& \mathbf{D}$ expenditures are grossed up by the average annual growth rate of physical capital for the period 1954 to 1961 plus the depreciation rate for $R \& D$ capital, which is assumed to be 10 percent. The 10 percent depreciation rate for $\mathbf{R} \& \mathrm{D}$ capital has been used by many studies. Recently, Nadiri and Prucha (1993) estimated the $\mathrm{R} \& \mathrm{D}$ depreciation rate to be 10 percent. The growth rates are obtained for each industry from the following regressions:

$$
\ln v_{p}(t)=\alpha+\beta t
$$

where $v_{p}(t)=$ physical capital stock, $t=$ time. The before-tax rental rate on $\mathbf{R} \& \mathbf{D}$ capital (WRC) is defined by:

$$
W R C=p_{r}\left(r+\delta_{r}\right)\left(\left(1-u_{c}\right)\left(1-I T C_{r}\right)-u_{c} d\right) /\left(1-u_{c}\right) .
$$

where $p$, is the $R \& D$ investment price, $\delta_{r}$ is the $R \& D$ capital depreciation rate, $I T C$, is the $\mathbf{R} \& \mathrm{D}$ investment tax credit, $d$ is the present value of incremental $\mathbf{R} \& \mathbf{D}$ investment allowance.

The present value of incremental investment allowance at time $t$ is: 


$$
d=\operatorname{IIA}\left(1-\sum_{t=1}^{3} \frac{1 / 3}{(1+I)^{t}}\right)
$$

where $I I A$ is the incremental investment allowance rate. If current $R \& D$ investment expenditures exceed an average of $\mathbf{R} \& \mathbf{D}$ expenditures in the past three years. then a tax reduction is allowed on the $\mathrm{R} \& \mathrm{D}$ expenditures in period $t$ at the rate $\| A$.

The variables for Japanese industries are defined in a similar fashion to the Canadian data. The quantity of output (YJ) is gross output in billions of 1985 yen. The price of output (PJ) is the gross output price index. The quantity of labour (VIJ) is labour compensation in billions of 1985 yen. The price of labour (WLJ) is an index. The quantity of materials (VMJ) is an aggregation of energy and non-energy materials in billions of 1985 yen. The price of materials (WMJ) is an index of energy and non-energy materials prices. The quantity of physical capital (VKJ) is net capital stock in billions of 1985 yen, obtained by summing net investment from gross investment using an aggregate total economy depreciation rate. The depreciation rate is constructed as a Divisia index of depreciation rates using total economy disaggragate capital and the price of investment [Dean, Darrough, Neef (1990)]. The benchmark net capital stock for each industry is constructed by multiplying gross capital stock for each industry by the ratio of net to gross capital for the total economy in 1962. The rental rate of physical capital is defined in a similar way to the Canadian counterpart. Since investment tax credit is zero for Japan, the rental rate for the Japanese physical capital (WKJ) is:

$$
W K J=p_{k}\left(r+\delta_{k}\right)\left(1-u_{c} z\right) /\left(1-u_{c}\right)
$$

The R \& D capital stock (VRJ) is defined similarly to the Canadian data; but the R \& D 
deflator is that for the total economy because the two-digit SIC deflators are not available. The rental rate of $R \& D$ capital is derived using a similar formula to the Canadian data. Since $\mathbf{R} \& \mathbf{D}$ capital is immediately expensed in Japan, the rental rate of the Japanese $\mathbf{R}$ \& D capital (WRJ) is defined by:

$$
W R J=p_{x}\left(I+\delta_{Y}\right) .
$$

Tables $4.2-4.11$ provide the means and standard deviations, minima and maxima of the variables for each Canadian and Japanese industry.

\subsection{Purchasing Power Parity}

To assess the international R \& D spillovers between Canadian and Japanese industries, it is essential to combine the Canadian and Japanese data. Thus, it is necessary to compare Canadian dollar values with those in Japanese yen. Our measure of international comparison is the cost of an industry in Japan relative to the cost in Canada.

Relative costs between Canadian and Japanese industries can be summarized by means of purchasing power parities. The purchasing power parity for a specific industry's cost is the number of yen required in Japan to produce an amount of output that would cost one dollar to produce in Canada. Purchasing power parity has the same dimension as the yen-to-dollar exchange rate. However, it is different from the exchange rate in that it reflects the relative prices of the output and inputs that make up the industry's production cost.

In this study, we estimate purchasing power parities for the ten Japanese and Canadian industries in the period 1962-1986. These are relative costs of production of 
Table 4.2

Statistical Description of Date: Chemical Products

\begin{tabular}{|l|r|r|r|r|}
\hline VARIABLE & \multicolumn{1}{|c|}{ MEAN } & STD. DEV & MINIMUM & MAXIMUM \\
\hline PC & 0.52099 & 0.28288 & 0.27228 & 1.00000 \\
\hline YC & 12244.68223 & 4149.68004 & 5907.87695 & 19451.38281 \\
\hline PJ & 0.74079 & 0.23845 & 0.49608 & 1.12108 \\
\hline YJ & 14062.51238 & 5755.13361 & 4191.59717 & 23001.46875 \\
\hline WLC & 0.46744 & 0.30055 & 0.15806 & 1.07527 \\
\hline VLC & 2773.31634 & 217.55681 & 2267.66992 & 3034.41919 \\
\hline WLJ & 0.71258 & 0.24568 & 0.42696 & 1.05797 \\
\hline VLJ & 1749.71365 & 697.23985 & 610.71497 & 3027.77441 \\
\hline WMC & 0.50026 & 0.29823 & 0.23258 & 1.00942 \\
\hline VMC & 8509.41479 & 2947.30764 & 4125.46436 & 13682.63672 \\
\hline WMJ & 0.68236 & 0.25225 & 0.40297 & 1.04737 \\
\hline VMJ & 10291.34258 & 3838.09939 & 3696.20459 & 15588.77930 \\
\hline WKC & 0.16076 & 0.05245 & 0.08707 & 0.25839 \\
\hline VKC & 4702.09447 & 2233.82052 & 2030.71692 & 8554.28516 \\
\hline WKJ & 0.13386 & 0.04084 & 0.07933 & 0.20874 \\
\hline VKJ & 5660.45915 & 2181.63926 & 1669.67456 & 8385.77246 \\
\hline WRC & 0.08822 & 0.05485 & 0.03148 & 0.18224 \\
\hline VRC & 1385.81355 & 83.22598 & 1218.33789 & 1550.30530 \\
\hline WRJ & 0.10815 & 0.04959 & 0.05026 & 0.17690 \\
\hline VRJ & 3238.26726 & 1436.54653 & 1411.40063 & 6193.52637 \\
\hline & & & & \\
\hline
\end{tabular}


Tuble 4.3

Stntistical Dexcription of Dantm: Electrical Products

\begin{tabular}{|l|r|r|r|r|}
\hline VARIABI.E & \multicolumn{1}{|c|}{ MEAN } & STD. DEV & MINIMUM & MAXIMUM \\
\hline PC & 0.71775 & 0.22107 & 0.47041 & 1.05523 \\
\hline YC & 7871.89647 & 3154.29938 & 3622.58936 & 15491.35254 \\
\hline PJ & 1.12974 & 0.12677 & 0.93590 & 1.33333 \\
\hline YJ & 13861.85360 & 12560.57032 & 2129.63403 & 44614.98438 \\
\hline WLC & 0.46894 & 0.29684 & 0.16489 & 1.06383 \\
\hline VLC & 4050.90210 & 301.09530 & 3303.99976 & 4512.62012 \\
\hline WLJ & 0.85099 & 0.19993 & 0.60799 & 1.12400 \\
\hline VLJ & 2488.07362 & 2284.36524 & 223.63152 & 8443.69336 \\
\hline WMC & 0.69619 & 0.22591 & 0.43254 & 1.02579 \\
\hline VMC & 4530.44240 & 1775.11442 & 2076.86401 & 8888.70410 \\
\hline WMJ & 0.84412 & 0.20144 & 0.59732 & 1.11740 \\
\hline VMJ & 10867.77585 & 8082.76991 & 2321.77002 & 30028.41602 \\
\hline WKC & 0.16458 & 0.05433 & 0.09096 & 0.26172 \\
\hline VKC & 927.36728 & 240.14750 & 584.10852 & 1533.76599 \\
\hline WKJ & 0.13386 & 0.04084 & 0.07933 & 0.20874 \\
\hline VKJ & 3898.68402 & 2655.10373 & 940.96997 & 11325.87012 \\
\hline WRC & 0.09750 & 0.05054 & 0.04149 & 0.18371 \\
\hline VRC & 3479.31850 & 1624.09286 & 1564.84338 & 7488.34814 \\
\hline WRJ & 0.10815 & 0.04959 & 0.05026 & 0.17690 \\
\hline VRJ & 4238.22321 & 2620.34498 & 1459.39600 & 10515.99414 \\
\hline
\end{tabular}


Table 4.4

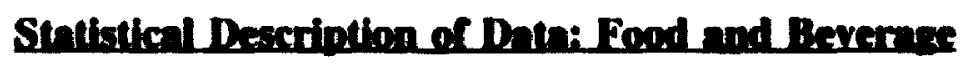

\begin{tabular}{|c|c|c|c|c|}
\hline VARIABLE & MEAN & STD. DEV. & MINIMUM & MAXIMUIM \\
\hline $\mathbf{P C}$ & 0.54581 & 0.27767 & 0.26037 & 1.03734 \\
\hline YC & 32741.84586 & 5803.79178 & 22190.04297 & 40737.11719 \\
\hline PJ & 0.65782 & 0.25267 & 0.34545 & 1.00909 \\
\hline YJ & 21188.45137 & 6501.15608 & 9846.87012 & 29079.71094 \\
\hline WLC & 0.46211 & 0.30956 & 0.13981 & 1.06724 \\
\hline VLC & 6748.28848 & 226.89729 & 6342.55127 & 7195.35693 \\
\hline WLJ & 0.66356 & 0.26886 & 0.30338 & $1.0 \times 240$ \\
\hline VLJ & 2638.14563 & 956.44410 & | 189.04504 & 4323.93799 \\
\hline WMC & 0.54581 & 0.27767 & 0.26037 & 1.03734 \\
\hline VMC & 22418.38391 & 4235.13854 & 15108.13184 & 28705.15625 \\
\hline WMJ & 0.66106 & 0.26897 & 0.30094 & $1.0 \times 1 \times 10$ \\
\hline $\mathbf{V M J}$ & 14119.15734 & 3964.70066 & 7390.27881 & 19185.74805 \\
\hline WKC & 0.15784 & 0.05818 & 0.08761 & $0.27 / 47$ \\
\hline VKC & 4162.62112 & 680.95667 & 2971.63135 & 5211.52197 \\
\hline $\mathbf{W K J}$ & 0.13386 & 0.04084 & 0.07933 & 0.20874 \\
\hline $\mathbf{V K J}$ & 3097.22557 & 1439.26158 & 729.69000 & 5129.77979 \\
\hline WRC & 0.08837 & 0.05573 & 0.02930 & 0.18414 \\
\hline VRC & 495.04838 & 145.20504 & 277.74994 & 756.60992 \\
\hline WR & 0.10815 & 0.04959 & 0.05026 & 0.17690 \\
\hline $\mathbf{V R}$ & 470.01040 & 212.15341 & 206.34062 & 908.26630 \\
\hline
\end{tabular}


Table 4.5

Stntistion Description of Datn: Fohricnted Metals

\begin{tabular}{|l|r|r|r|r|}
\hline VARIABLE & \multicolumn{1}{|c|}{ MEAN } & STD. DEV & MINIMUM & MAXIMUM \\
\hline PC & 0.54288 & 0.28369 & 0.26632 & 1.03627 \\
\hline YC & 11949.43133 & 2396.55072 & 6714.12061 & 14923.22168 \\
\hline PJ & 0.72264 & 0.22243 & 0.47721 & 1.00109 \\
\hline YJ & 7238.15249 & 3139.19695 & 1813.17517 & 12798.22852 \\
\hline WLC & 0.4915 & 0.29873 & 0.17088 & 1.01112 \\
\hline VLC & 4138.81910 & 378.49830 & 3258.55444 & 4663.54346 \\
\hline WLJ & 0.72316 & 0.23396 & 0.45630 & 1.02755 \\
\hline VLJ & 2496.91316 & 1047.67397 & 662.28601 & 4292.45947 \\
\hline WMC & 0.54461 & 0.29384 & 0.26091 & 1.03950 \\
\hline VMC & 6935.76924 & 1457.94777 & 3902.74561 & 8832.24707 \\
\hline WMJ & 0.71348 & 0.23480 & 0.45005 & 1.02161 \\
\hline VMJ & 4351.02453 & 1942.88167 & 1169.30298 & 7964.82227 \\
\hline WKC & 0.16495 & 0.05899 & 0.08263 & 0.27663 \\
\hline VKC & 1522.33451 & 255.66554 & 1020.23303 & 1832.77893 \\
\hline WKJ & 0.13386 & 0.04084 & 0.07933 & 0.20874 \\
\hline VKJ & 2327.88201 & 1370.91161 & 282.76260 & 4631.67236 \\
\hline WRC & 0.09309 & 0.05585 & 0.03310 & 0.19272 \\
\hline VRC & 141.28126 & 71.48110 & 35.65827 & 257.24200 \\
\hline WRJ & 0.10815 & 0.04959 & 0.05026 & 0.17690 \\
\hline VRJ & 248.35764 & 169.78592 & 54.34618 & 598.06232 \\
\hline & & & & \\
\hline
\end{tabular}


Table 4.6

Sintistical Description of Dain: Non-electrical Mechinery

\begin{tabular}{|l|r|r|r|r|}
\hline VARIABLE & \multicolumn{1}{|c|}{ MEAN } & STD. DEV & MINIMUM & MAXIMUM \\
\hline PC & 0.52082 & 0.27891 & 0.25335 & 1.02987 \\
\hline YC & 6560.40729 & 1857.89213 & 2799.11523 & 9704.49219 \\
\hline PJ & 0.79422 & 0.18879 & 0.57784 & 1.02054 \\
\hline YJ & 15730.80545 & 9113.67905 & 3507.87427 & 32198.53711 \\
\hline WLC & 0.49055 & 0.29898 & 0.16993 & 1.02987 \\
\hline VLC & 2194.73904 & 344.02344 & 1428.15588 & 2834.84863 \\
\hline WLJ & 0.77119 & 0.20648 & 0.53341 & 1.02732 \\
\hline VLJ & 3654.62867 & 2065.39624 & 828.76483 & 7668.66260 \\
\hline WMC & 0.52032 & 0.27336 & 0.25911 & 1.01215 \\
\hline VMC & 3737.28830 & 1118.07018 & 1424.78394 & 5586.16650 \\
\hline WMJ & 0.76546 & 0.20792 & 0.52665 & 1.02674 \\
\hline VMJ & 10626.71207 & 6089.60118 & 2437.23853 & 21617.30469 \\
\hline WKC & 0.16868 & 0.05715 & 0.09104 & 0.27820 \\
\hline VKC & 737.37992 & 263.05339 & 358.14072 & 1196.76587 \\
\hline WKJ & 0.13386 & 0.04084 & 0.07933 & 0.20874 \\
\hline VKJ & 4079.21915 & 2132.59339 & 745.57068 & 7910.03711 \\
\hline WRC & 0.09261 & 0.05532 & 0.03336 & 0.18949 \\
\hline VRC & 515.22562 & 225.04150 & 177.56334 & 832.96497 \\
\hline WRJ & 0.10815 & 0.04959 & 0.05026 & 0.17690 \\
\hline VRJ & 1152.01484 & 648.51660 & 325.86523 & 2428.64575 \\
\hline
\end{tabular}


Toble 4.7

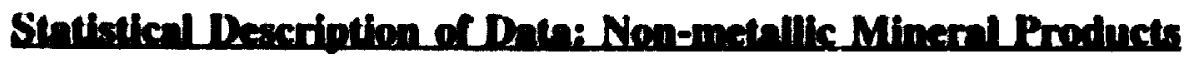

\begin{tabular}{|c|c|c|c|c|}
\hline VARIABLEE & MEAN & STD. DEV. & MINIMUM & MAXIMUM \\
\hline PC & 0.51101 & 0.28020 & 0.24033 & 1.04493 \\
\hline YC & 5265.23751 & 1026.94151 & 3330.67310 & 6742.20508 \\
\hline PJ & 0.65530 & 0.27185 & 0.37393 & 1.03507 \\
\hline $\mathbf{Y J}$ & 6616.65178 & 2404.22072 & 1919.08289 & 9404.66406 \\
\hline WLC & 0.46552 & 0.30415 & 0.14374 & 1.03413 \\
\hline VLC & 1732.73883 & 121.63989 & 1496.55066 & 1931.14294 \\
\hline WLJ & 0.73005 & 0.23446 & 0.45647 & 1.05231 \\
\hline VLJ & 1412.77638 & 632.55381 & 407.59674 & 2510.28979 \\
\hline WMC & 0.50520 & 0.28099 & 0.23600 & 1.00000 \\
\hline VMC & 2925.56978 & 584.66746 & 1838.45105 & 3818.74707 \\
\hline WMJ & 0.66035 & 0.26340 & 0.35183 & 1.03003 \\
\hline VMJ & 3991.39339 & 1572.59949 & 1163.95642 & 5544.90234 \\
\hline WKC & 0.14197 & 0.04853 & 0.07628 & 0.23770 \\
\hline VKC & 1656.36434 & 276.36155 & I 182.03406 & 2068.38892 \\
\hline WKJ & 0.13386 & 0.04084 & 0.07933 & 0.20874 \\
\hline $\mathbf{V K J}$ & 2251.94429 & 1014.37570 & 531.01971 & 3477.10498 \\
\hline WRC & 0.09261 & 0.05532 & 0.03336 & 0.18949 \\
\hline VRC & 515.21242 & 225.05073 & 177.52779 & 832.96216 \\
\hline WRJ & 0.10815 & 0.04959 & 0.05026 & 0.17690 \\
\hline VRJ & 387.33263 & 33.29928 & 138.38139 & 941.28107 \\
\hline
\end{tabular}


Table 4.8

Stntintical Description ol Datn: Proer and Allied Products

\begin{tabular}{|l|r|r|r|r|}
\hline VARIABLE & \multicolumn{1}{|c|}{ MEAN } & STD. DEV & MINIMUM & MAXIMUM \\
\hline PC & 0.52946 & 0.28767 & 0.25104 & 1.04167 \\
\hline YC & 14752.19992 & 2901.87172 & 9253.49512 & 19499.49219 \\
\hline PJ & 0.68341 & 0.25947 & 0.38799 & 1.05175 \\
\hline YJ & 6078.30081 & 2015.69336 & 2277.35620 & 8591.94912 \\
\hline WLC & 0.44730 & 0.30198 & 0.1 .298 & 1.06157 \\
\hline VLC & 4577.51708 & 277.08507 & 016.08032 & 5079.53418 \\
\hline WLJ & 0.68355 & 0.25826 & 0.38034 & 1.03014 \\
\hline VLJ & 779.78439 & 295.70454 & 266.38800 & 1204.79028 \\
\hline WMC & 0.54183 & 0.27665 & 0.27336 & 1.00000 \\
\hline VMC & 8735.49904 & 2229.22469 & 4875.21289 & 12831.94727 \\
\hline WMJ & 0.67158 & 0.25969 & 0.37003 & 1.01544 \\
\hline VMJ & 4445.95805 & 1380.76696 & 1790.13464 & 6086.84277 \\
\hline WKC & 0.13119 & 0.04088 & 0.07447 & 0.21152 \\
\hline VKC & 7656.69240 & 1801.03755 & 4307.22021 & 10437.75879 \\
\hline WKJ & 0.13386 & 0.04084 & 0.07933 & 0.20874 \\
\hline VKJ & 1876.54670 & 779.65315 & 625.45520 & 2929.59888 \\
\hline WRC & 0.08973 & 0.05428 & 0.03207 & 0.18200 \\
\hline VRC & 990.03447 & 109.58031 & 844.53424 & 1143.44653 \\
\hline WRJ & 0.10815 & 0.04959 & 0.05026 & 0.17690 \\
\hline VRJ & 134.83328 & 45.10825 & 70.44810 & 216.87912 \\
\hline & & & & \\
\hline
\end{tabular}


Tante 4.9

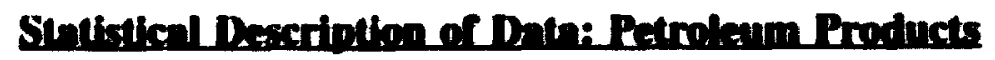

\begin{tabular}{|c|c|c|c|c|}
\hline VARIABLE & MEAN & STD. DEV. & MINIMUM & MAXIMUM \\
\hline $\mathbf{P C}$ & 0.35026 & 0.31812 & 0.10039 & 1.00000 \\
\hline YC: & 21959.43641 & 5613.78056 & 12479.12109 & 29779.01953 \\
\hline $\mathbf{P J}$ & 0.49901 & 0.34260 & 0.18320 & 1.09707 \\
\hline YJ & 14555.89418 & 5645.27047 & 3624.90967 & 19871.86914 \\
\hline WIC & 0.44931 & 0.31254 & 0.12839 & 1.04384 \\
\hline VLC & 803.65824 & 123.43856 & 596.04187 & 1091.28308 \\
\hline WLJ & 0.71195 & 0.24289 & 0.41948 & 1.03140 \\
\hline VIS & 235.00431 & 102.50048 & 84.02004 & 427.07291 \\
\hline WMC & 0.34350 & 0.31870 & 0.09331 & 1.00000 \\
\hline VMC & 20703.54621 & 5310.43667 & II742.55762 & 28657.99219 \\
\hline WMS & 0.56662 & 0.28980 & 0.28510 & 1.00500 \\
\hline VMJ & 9183.35459 & 6076.04312 & 1095.40454 & 17969.90234 \\
\hline WKC & 0.17459 & 0.04416 & 0.11225 & 0.25855 \\
\hline VKC & 3702.59365 & 1074.83178 & 2195.74512 & 5278.50146 \\
\hline WKJ & 0.13386 & 0.04084 & 0.07933 & 0.20874 \\
\hline $\mathbf{V K J}$ & 1780.19996 & 860.71620 & 450.85861 & 2795.65479 \\
\hline WRC & 0.07352 & 0.05911 & 0.02006 & 0.18200 \\
\hline VRC & 1953.18004 & $431.46 \% 61$ & 1556.04651 & 2734.20972 \\
\hline WR & 0.10815 & 0.04959 & 0.05026 & 0.17690 \\
\hline VRJ & 184.19708 & 108.38156 & 64.41419 & 412.61691 \\
\hline
\end{tabular}


Table 4.10

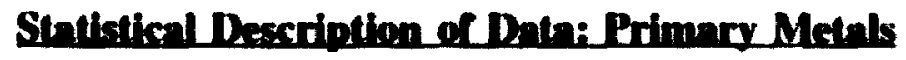

\begin{tabular}{|c|c|c|c|c|}
\hline VARIABLE & MEAN & STD. DEV. & MINIMIIM & MAXIMIIM \\
\hline PC & 0.51866 & 0.26158 & 0.28466 & 1.05142 \\
\hline YC & $26 \mid 67.626 .52$ & 10031.67030 & 8550.01758 & $4424.5 .21 \times 7.5$ \\
\hline $\mathbf{P J}$ & 0.78226 & 0.18284 & 0.57242 & 1.01 .343 \\
\hline $\mathbf{Y J}$ & 18655.43910 & 10086.32189 & 3587.16724 & $.1671 \times .02344$ \\
\hline WLC & 0.46364 & 0.29471 & 0.15328 & I.057:K \\
\hline VLC & 6166.29247 & 930.59807 & 3991.050105 & $7644.2 \times 15.3$ \\
\hline WLJ & 0.76351 & 0.21022 & 0.52666 & 1.02844 \\
\hline VU & 3774.18504 & 2147.77651 & $795.10 k 64$ & жk5.29x.53 \\
\hline WMC & 0.51087 & 0.27409 & 0.25295 & $|.07| 8 \mid$ \\
\hline VMC & $19128.6204 \mid$ & 7187.11837 & 6466.77588 & $.32441 .9 \times 242$ \\
\hline $\mathbf{W M J}$ & 0.75927 & 0.21127 & 0.52161 & I.0279x \\
\hline $\mathbf{V M J}$ & $|2725.77| 6 \mid$ & 6801.45710 & 2840.06567 & $26(1) 34.84180$ \\
\hline WKC & 0.14915 & 0.05656 & 0.07186 & 0.25617 \\
\hline VKC & 2787.60926 & 922.42611 & 1346.333398 & 4475.85498 \\
\hline WKJ & 0.13386 & 0.04084 & 0.07933 & $0.21 \times 74$ \\
\hline VKJ & 4783.60033 & 2564.41056 & 943.33972 & $0437.49 x 0.5$ \\
\hline WRC & 0.08991 & 0.05399 & 0.03223 & $0.182(x)$ \\
\hline VRC & 2912.29413 & 400.54327 & 2475.41528 & 3947.85986 \\
\hline WR & 0.10815 & 0.04959 & 0.05026 & 0.17640 \\
\hline V.IJ & 2311.61961 & 1578.09772 & 595.44476 & 5676.103564 \\
\hline
\end{tabular}


i'sble 4.11

Stntistica Description of Datg: Transportation Equipment

\begin{tabular}{|l|r|r|r|r|}
\hline VARIABLE & \multicolumn{1}{|c|}{ MEAN } & \multicolumn{1}{|c|}{ STD. DEV } & MINIMUM & MAXIMUM \\
\hline PC & 0.55760 & 0.29952 & 0.25560 & 1.01833 \\
\hline YC & 16354.77266 & 2711.59241 & 10318.21973 & 19980.38086 \\
\hline PJ & 0.73904 & 0.22909 & 0.48615 & 1.06168 \\
\hline YJ & 27285.90883 & 10466.98193 & 8338.54688 & 39001.62891 \\
\hline WLC & 0.44165 & 0.30521 & 0.13745 & 1.08225 \\
\hline VIC & 4770.96685 & 368.36274 & 3974.35425 & 5397.50342 \\
\hline WLJ & 0.73005 & 0.23446 & 0.45647 & 1.05231 \\
\hline VIJ & 1926.96468 & 901.75796 & 538.09845 & 3479.92944 \\
\hline WMC & 0.56508 & 0.29672 & 0.25378 & 1.00705 \\
\hline VMC & 11228.01246 & 2007.60105 & 6990.68115 & 13986.81934 \\
\hline WMJ & 0.70500 & 0.23886 & 0.43784 & 1.03202 \\
\hline VMJ & 22481.94742 & 7903.36975 & 7698.47949 & 31533.95508 \\
\hline WKC & 0.12945 & 0.04466 & 0.06840 & 0.21530 \\
\hline VKC & 7182.59027 & 1444.48494 & 4614.76172 & 9206.37500 \\
\hline WKJ & 0.13386 & 0.04084 & 0.07933 & 0.20874 \\
\hline VKJ & 7817.74581 & 3083.91486 & 2419.47510 & 11035.37793 \\
\hline WRC & 0.08851 & 0.05406 & 0.02524 & 0.18200 \\
\hline VRC & 1132.18005 & 202.79402 & 822.73846 & 1403.40955 \\
\hline WRJ & 0.10815 & 0.04959 & 0.05026 & 0.17690 \\
\hline VRJ & 1137.81352 & 486.40969 & 576.56055 & 2189.45923 \\
\hline
\end{tabular}


each industry in the two countries in terms of yen per dollar. To account for changes in the relative cost of production. we need to estimate the purchasing power parity of the relative prices of outputs and inputs. The methodology for estimating purchasing power parities is hased on Kravis-Heston-Summers (1978), Jorgenson-Nishimizu (1978. 1981 ). Jorgenson-Kuroda-Nishimizu (1987), Jorgens,on-Kuroda (1990) and Fuss-Waverman (1990). The data on production in Japan and Canada are treated as separate sets of observations. Purchasing power parity measures for output are ohtained by dividing the Japanese price by the Canadian price of the output for each industry. Purchasing power parities for inputs are defined in the same manner using Japanese and Canadian prices of labour, materials. physical capital and $\mathbf{R} \& \mathbf{D}$ capital.

Suppose that we observe the price of output of the ith industry in Japan and Canada in terms of domestic currencies. To estimate purchasing power parity for output of industry $i$, we follow four steps:

1. Define purchasing power parity in the base year PPP, (0) as:

$$
P P P_{i}(0)=\frac{p_{i}(J A P)}{p_{i}(C A N)},
$$

where $p_{i}(J A P)$ and $p_{1}(C A N)$ are the domesic prices (not price indices, of output in Japan and Canada in period 0.

2. Select period 0 as the base year which we take to be 1985. Normalize the price of output for industry $i$ in Canada at unity in 1985. This yields an index in perioxl $t$ defined as $p_{1}(C A N, t)$. In Japan. normalize the price of output for the ith industry at purchasing power parity in 1985 (which is $P P P,(0))$. This yields a price index in period $t$ defined 
as $p_{1}(J A P, t)$. This Japanese price index, in the period of normalization, is not unity, hecause the index is purchasing power parity adjusted.

3. Combine steps 1 and 2 to construct purchasing power parities for all years:

$$
P P P_{1}(t)=P P P_{1}(0) \frac{p_{i}(J A P, t) / p_{i}(J A P, 0)}{p_{1}(C A N, t) / p_{1}(C A N, 0)} .
$$

where $P P P_{i}(t)$ is the purchasing power parity in period $t$. Notice that, if $t=0$, then $\operatorname{PPP}_{1}(t)=\operatorname{PPP},(0)$

4. Take the ratio of the purchasing power parity obtained in step 3 to the yen-to-dollar exchange rate $E(t)$ :

$$
P_{i}(J A P, C A N, t)=\frac{P P P_{i}(t)}{E(t)},
$$

where $P,(J A P, C A N, t)$ is the output purchasing power parity price index. This step yields the price index of output for the ith Japanese industry in Canadian dollars.

We perform these steps for output and the inputs for each Japanese industry. Table 4.12 shows the purchasing power parities for industry output, labour, materials, physical capital and R \& D capital in 1985. 
Table 4.12

\section{The Japanese Price Index. Transformed by the Burchnsing Power Parity Index at 1985 (Conadinn Price $=1.000)$}

\begin{tabular}{|l|c|c|c|c|c|}
\hline \multicolumn{1}{|c|}{$\begin{array}{l}\text { Japanese } \\
\text { Industry }\end{array}$} & $\begin{array}{c}\text { Output } \\
\text { Price }\end{array}$ & $\begin{array}{c}\text { Labour } \\
\text { Price }\end{array}$ & $\begin{array}{c}\text { Materials } \\
\text { Price }\end{array}$ & $\begin{array}{c}\text { Phy. } \\
\text { Cap. } \\
\text { Price }\end{array}$ & $\begin{array}{c}\text { R \& D } \\
\text { Capital } \\
\text { Price }\end{array}$ \\
\hline Chemical Products & 0.31309 & 0.15258 & 0.46539 & 0.56758 & 0.53973 \\
\hline Electrical Products & 0.31085 & 0.41496 & 0.55384 & 0.55273 & 0.58895 \\
\hline Food \& Beverage & 0.71624 & 0.27268 & 0.60548 & 0.60990 & 0.49858 \\
\hline Fabricated Metals & 0.40973 & 0.09464 & 0.51613 & 0.44849 & $0.50 \times 67$ \\
\hline Non-electrical Machinery & 0.29045 & 0.35925 & 0.36750 & 0.72029 & 0.44008 \\
\hline Non-metallic Mineral Products & 0.41103 & 0.24836 & 0.50255 & 0.39678 & 0.52548 \\
\hline Paper \& Allied Products & 0.34759 & 0.23410 & 0.39436 & 0.50303 & 0.44506 \\
\hline Petroleum Products & 0.99584 & 0.30974 & 0.23233 & 0.44900 & 0.96676 \\
\hline Primary Metals & 0.38314 & 0.27916 & 0.55845 & 0.43243 & 0.61221 \\
\hline Transportation Equipment & 0.51665 & 0.35999 & 0.43981 & 0.40975 & 0.66278 \\
\hline
\end{tabular}




\section{REFERENCES}

Bernstein. J.I. (1989). "The Structure of Canadian Industrial R \& D Spillovers and the Rales of Return to R \& D", Journal of Industrial Economics, 37(3), pp. 315-328.

Bernstein. J.I. (1986), Research and Development, Incentives, and the Structure of Production and Financing, Toronto: The University of Toronto Press.

Dean, E., M. Darrough, and A. Neef ( 1990), "Alternative Measures of Capital Inputs in Japanese Manufacturing", in Charles R. Hulten (ed.), Productivity Growth in Japan and the United States, Chicago: The University of Chicago Press.

Denny. M., J.I. Bernstein, M. Fuss, S. Nakamura and L. Waverman, "Productivity in Manufacturing Industries, Canada, Japan and the United States, 1953-1986: Was the 'Productivitv Slowdown' Reversed?", Canadian Joumal of Economics, XXV No.3 August, 1992, pp. 584-603.

Fuss M. and L. Waverman (1990), "Productivity Growth in the Motor Vehicle Industry, 1970-1984: A Comparison of Canada, Japan, and the United States", in Charles R. Hulten (ed.), Productivity Growth in Japan and the United States, Chicago: The University of Chicago Press.

Hayashi F. (1990), "Taxes and Corporate Investment in Japanese Manufacturing", in Charles R. Hulten (ed.), Productivity Growth in Japan and the United States, Chicago: The University of Chicago Press. 
Jorgenson, D.W. and M. Kuroda (1990), "Productivity and International Competitiveness in Japan and the United States, 1960-1985". in C. R. Hulten (ed.), Proxductivity Growh in Japan and the United States, Chicago: The University of Chicago Press.

Jorgenson. D.W., M. Kuroda, and M. Nishimizu (1987). "Japan-U.S. Industry-level Productivity Comparisons, 1960-1979". Joumal of the Japunese and Intermational Economies 1, No. I (March), pp. 1-30.

Jorgenson, D.W., and M. Nishimizu (1981), "International Differences in Levels of Technology: A Comparison Between U.S. and Japanese Industries", in Intemational Roundtable Congress Proceedings, Tokyo: Institute of Statistical Mathematics.

Jorgenson, D.W., and M. Nishimizu (1978), "U.S. and Japanese Economic Growth. 19521974: An Intemational Comparison", Economic Joumal 88, No. 352 (December), pp. $707-726$.

Kravis, I.B., A. Heston, and R. Summers (1978), International Comparisoms of Real Product and Purchasing Power. Baltimore: Johns Hopkins University Press.

Nadiri, M.I. and I.R. Prucha (1993), "Estimation of the Depreciation Rate of Physical and R \& D Capital in the U.S. Total Manufacturing Industries", NBER Working Puper \#451. 


\section{CHAPTER 5 ESTIMATION RESULTS AND SPILLOVER ELASTICITIES}

\section{I Introduction}

In this chapter, we discuss the estimation results, the test for the degree of returns to scale and the test for the existence of international spillovers between Canada and Japan. We derive the formulae for the spillover elasticities and interpret the effect of spillovers on the input-output ratios (or factor intensities) and average variable cost of the Canadian and Japanese industries. The chapter is organized in the following way. Section 2 describes the model estimation, the test for the degree of returns to scale in each industry and the test for the existence of international R \& D spillovers between Canada and Japan. In Section 3 the formulae for the spillover elasticities are derived and the effects of spillovers on factor intensities and average variable cost are discussed for cach industry. Section 4 summarizes the findings of this chapter.

\subsection{Model Estimation, the Degree of Returns to Scale and the Existence of Spillovers}

As we presented in Chapter 3, the estimation model consists of the equilibrium factor demand conditions (equation sets (3.10) and (3.12)). There are 4 equations and 22 paramelers to be estimated. The Canadian and Japanese data are pooled and the model is estimated for each of the ten industries: chemical products, electrical products, food and beverage, fabricated metals, non-electrical machinery, non-metallic mineral products, paper and allied products, petroleum products, primary metals and transportation equipment industries. The equations are simultaneously estimated by the full information maxinum likelihood estimator. 
In order to allow for differences in the Canadian and Japanese industries. we have put dummy variables in the estimation on the intercept terms $\beta$. the capital intensity parameters $\varphi_{k}$ and the spillover parameters $\eta_{k y}[$ see equation (3.10) and (3.12)]. We also allow the variance of the error terms to be different for the two countries.

In Chapter 3, we pointed out that some restrictions on the paranketers $B$ are necessary in order to identify the model. These are $\beta_{11}+\beta_{12}=0$, and $\beta_{12}+\beta_{22}=0$. It should be noted that the unit variable cost function must be concave in the non-capital input prices. In order to guarantec this condition on the factor prices we define.

$$
\left[\begin{array}{ll}
\beta_{11} & \beta_{12} \\
\beta_{12} & \beta_{22}
\end{array}\right]=-\left[\begin{array}{cc}
b_{11} & 0 \\
b_{12} & b_{22}
\end{array}\right]\left[\begin{array}{cc}
b_{11} & b_{12} \\
0 & b_{22}
\end{array}\right]
$$

Thus the identification and curvature conditions imply that $\beta_{11}=-b_{11}{ }^{2}$. The unit variahle cost function must also be convex in the capital inputs. Thus we define $\alpha_{12}=\lambda \alpha_{11} \alpha_{22}$ so that, when $|\lambda|<1$, the unit variable cost function is convex in the capilal inputs as long as $\alpha_{11}>0$ and $\alpha_{22}>0$.

In order to determine the degree of retums to scale in each Canadian and Japanese industry, a two-tier likelihood ratio test is performed to find out: 1) whether the Canadian and Japanese industries experience the same degree of returns to scale: and 2) if the returns to scale are constant. In Table 5.1, we have listed the likelihood function values and the scale parameters of the different models. The returns to scale parameter in the estimation model is $\theta^{-1}$; the subscript $c$ refers to Canada and the subscript $j$ to Japan. In the table, the scale parameter estimates are in brackets.

We first test whether $\theta_{c}$ is equal to $\theta_{j}$. If the chi-square statistics are greater than 


\section{Table 5.1}

Indusitry

Chemical

Proxducts

Electrical

Products

Foxd and

Beverage

Fabricated

Metals

Non-electrical

Machinery

Non-metallic

Mineral Products

Paper \& Allied

Products

Petroleum

Products

Primary

Metals

Transportation

Equipment
Iog of Likellhood Function Values

$$
\begin{aligned}
& \theta_{c} \neq \theta_{1} \quad \theta_{c}=\theta_{1} \quad \theta_{c}=\theta_{i}=\theta=1 \quad \theta_{c}=1 \quad \theta_{3}=1 \\
& \theta_{c} \neq 1 \quad \theta_{1} \neq 1
\end{aligned}
$$

395.584

$$
\begin{array}{ll}
412.518 & 412.396 \\
(c=1.16893) & (1.17405) \\
(j=1.17590) &
\end{array}
$$

$\begin{array}{lll}346.092 & 346.086 & 344.520 \\ (c=.97146) & (.975388) & \\ (j=1.00965) & & \end{array}$

683.870 680.59

$683.869 \quad 681.434$

$(j=1.08210)(c=.95316)$

$(j=1.08290)$

(1.03921)

513.707

(1.11627)

$515.076 \quad 448.760$

$(j=.86253) \quad(c=1.05359)$

( $c=1.17524)$

$(j=I .03202)$

$\begin{array}{lll}441.725 & 440.361 & 431.198 \\ (c=.98604) & (.93803) & \\ (j=.94204) & & \end{array}$

$\begin{array}{ll}460.320 & 457.710 \\ (c=1.26013) & (1.43289) \\ (j=1.43107) & \end{array}$

$454.257 \quad 441.841$

$(j=1.25724)(c=.98833)$

486.386

485.246

484.794

$(c=1.02848) \quad(1.01848)$

$(j=.99717)$

618.364

$(c=.93239)$

$(j=.97486)$

$618.172 \quad 615.138$

(.92797)

480.742

390.310

$385.620 \quad 474.094$

$(c=1.30215)$

(1.40313)

$(j=1.42970)$

$(j=1.54044)(c=.97291)$

524.226

514.576

(.98353)

$\mathbf{5 0 3 . 0 1 4} \quad \mathbf{5 2 2 . 5 7 8}$

(c=.92478)

$(j=1.12811)(c=.88901)$ 
the chosen value of $\chi_{n .3 .1}^{2}=3.84$, we reject the hypothesis of $\theta_{r}$ and $\theta_{1}$ heing equal. Table 5.2 summarizes the test results: the test statistics are in hrackets. The first-tier tests in the table show that the degree of returns to scale is equal in chemical products. electrical products, non-electrical machinery, paper and allied products and petroleum products industries. However, the degree of returns to scale is different in the other five industries: food and beverage, fabricated metals, non-metallic mineral products, primary metals and iransportation equipment.

The second-tier test is to find out whether or not there are constant retums to scale. From Table 5.2, we see that there are differences across industries. Among the five industries that experience the same degree of retums to scale in both countries, we find that we reject the hypothesis of constant returns to scale in chemical products, nonelectrical machinery and petroleum products industries. In the electrical products and paper and allied products industries, the hypothesis of constant returns to scale is not rejected. For the industries where the degree of returns to scale differs between the countries; namely, food and beverage, fabricated metals, non-metallic mineral products, primary metals and transportation equipment, we have further tested whether the Canadian or the Japanese scale parameter is equal to one. Our results show that the hypothesis of constant retums to scale is rejected for all relevant Canadian or Japanese industries except the Canadian food and beverage industry and the Japanese Iransportation equipment industry. The latter two industries are found to exhibit constant returns to scale.

It should be noted that, if the critical value is $\chi_{0(1) .1}^{2}=6.63$, then we find that the degree of retums to scale is different in only three industries; namely, fabricated metals. 
Table 5.2

\section{Likelihood Ratio Test of Degree of Returns to Scale (test statistics in parentheses)}

\begin{tabular}{|c|c|c|c|c|}
\hline Industry & $\begin{array}{l}H_{1}: \theta_{c}=\theta_{1} \\
H_{1}: \theta_{1} \neq \theta_{1}\end{array}$ & $\begin{array}{l}H_{10}: \theta_{c}=1 \\
H_{1}: \theta_{c} \neq 1\end{array}$ & $\begin{array}{l}H_{1}: \theta_{1}=1 \\
H_{1}: \theta_{,} \neq 1\end{array}$ & $\begin{array}{l}H_{0}: \theta=1 \\
H_{1}: \theta \neq 1\end{array}$ \\
\hline $\begin{array}{l}\text { Chemical } \\
\text { Products }\end{array}$ & $\begin{array}{l}H_{0}, \text { Not Rejecled } \\
(0.244)\end{array}$ & & & $\begin{array}{l}H_{0} \text { Rejected } \\
(33.624)\end{array}$ \\
\hline $\begin{array}{l}\text { Electrical } \\
\text { Products }\end{array}$ & $\begin{array}{l}H_{11} \text { Not Rejected } \\
(0.012)\end{array}$ & & & $\begin{array}{l}H_{0} \text { Not Rejected } \\
\text { (3.132) }\end{array}$ \\
\hline $\begin{array}{l}\text { Food and } \\
\text { Beverage }\end{array}$ & $\begin{array}{l}H_{n} \text { Rejected } \\
(6.558)\end{array}$ & $\begin{array}{l}\mathbf{H}_{1} \text { Not Rejected } \\
(\mathbf{0 . 0 0 2 )}\end{array}$ & $\begin{array}{l}H_{0} \text { Rejected } \\
(4.872)\end{array}$ & \\
\hline $\begin{array}{l}\text { Fabricated } \\
\text { Metals }\end{array}$ & $\begin{array}{l}H_{0} \text { Rejected } \\
\text { (17.784) }\end{array}$ & $\begin{array}{l}H_{0} \text { Rejected } \\
(15.046)\end{array}$ & $\begin{array}{l}H_{0} \text { Rejected } \\
\text { (147.678) }\end{array}$ & \\
\hline $\begin{array}{l}\text { Non-electrical } \\
\text { Machinery }\end{array}$ & $\begin{array}{l}H_{0} \text { Not Rejected } \\
(2.728)\end{array}$ & & & $\begin{array}{l}H_{0} \text { Rejected } \\
(18.326)\end{array}$ \\
\hline $\begin{array}{l}\text { Non-metallic } \\
\text { Mineral Products }\end{array}$ & $\begin{array}{l}H_{0} \text { Rejected } \\
(5.220)\end{array}$ & $\begin{array}{l}\mathbf{H}_{0} \text { Rejected } \\
(12.126)\end{array}$ & $\begin{array}{l}H_{11} \text { Rejected } \\
\text { (36.958) }\end{array}$ & \\
\hline $\begin{array}{l}\text { Paper and Allied } \\
\text { Products }\end{array}$ & $\begin{array}{l}\mathrm{H}_{1} \text { Not Rejected } \\
(2.280)\end{array}$ & & & $\begin{array}{l}\mathrm{H}_{0} \text { Not Rejected } \\
(0.904)\end{array}$ \\
\hline $\begin{array}{l}\text { Petroleum } \\
\text { Products }\end{array}$ & $\begin{array}{l}H_{0} \text { Not Rejected } \\
(0.384)\end{array}$ & & & $\begin{array}{l}\mathrm{H}_{0} \text { Rejected } \\
(6.608)\end{array}$ \\
\hline $\begin{array}{l}\text { Primary } \\
\text { Metals }\end{array}$ & $\begin{array}{l}H_{0} \text { Rejected } \\
(180.864)\end{array}$ & $\begin{array}{l}H_{0} \text { Rejected } \\
(190.244)\end{array}$ & $\begin{array}{l}H_{0} \text { Rejected } \\
\text { (13.296) }\end{array}$ & \\
\hline $\begin{array}{l}\text { Transportation } \\
\text { equipment }\end{array}$ & $\begin{array}{l}H_{0} \text { Rejected } \\
(19.300)\end{array}$ & $\begin{array}{l}H_{0} \text { Rejected } \\
(42.424)\end{array}$ & $\begin{array}{l}\mathbf{H}_{0} \text { Not Rejec } \\
(3.296)\end{array}$ & \\
\hline
\end{tabular}


primary metals and transportation equipment. And among the seven industries that experience the same degree of returns to scale in both countries, the hypothesis of constant returns to scale is not rejected in electrical products. foud and heverage. paper and allied products and petroleum products. while, in the three industries where returns to scale are different, the hypothesis of constant returns is mot rejected only in the Japanese transportation equipment industry.

The next set of tests that we conduct concerns the existence of spillovers between Canada and Japan. Based on the previously accepted models. we first lest whether there are spillovers from Japan to Canada by setting the Canadian international spillover parameters $\eta_{22 x}$ and $\eta_{12 c}$ [see equation (3.10) and (3.12)] equal to zero. We reject the existence of international spillovers in Canada. if the likelihood ratio test statistic is larger than the value of $\chi_{\text {ons.2 }}^{2}=5.99$. Table 5.3 summarizes the test. The test statistics are shown in brackets. We see that the existence of R \& D spillovers from Japan to (anada is rejected for all industries except electrical products, food and beverage and primary metals.

It should be noted that, if the test statistic is set at $\chi_{1001.2}^{2}=9.21$, then $R \& D$ spillovers from Japan to Canada are found in only two industries: electrical products and primary metals.

Given the previous results that spillovers from Japan do not generally exist in Canada (except for electrical products, food and beverage and primary metals industries). we then test whether there are spillovers from Canada to Japan. We do this by selting the Japanese international spillover parameters $\eta_{22,}$ and $\eta_{12,}$ equal to zero. Table 5.3 
Tuble 5.3

\section{Whethood Bntio Tex of No Soll arers}

(test statistics in parentheses)

Industry

Chemical Products

Electrical Products

Food \& Beverage

Fabricuted Metals

Nom-electrical Machinery

Non-metallic Mineral Products

Paper A Allied Products

Petroleum Products

Primary Metals

Transportation Equipment
Japan to Canada

Nox Rejected

(5.912)

Rejected

(22.928)

Rejected

(9.580)

Not Rejected

(2.166)

Not Rejected

(2.540)

Not Rejected

(0.136)

Not Rejected

(5.954)

Nor Rejected

(3.106)

Reje:led

(145.358)

Not Rejected

(3.550)
Canada to Japan

Not Rejected

(1.064)

Rejected

(29.572)

Rejected

(9.240)

Rejected

(127.236)

Rejected (40.708)

Rejected

(20.232)

Rejected

(139.746)

Rejected (85.572)

Rejected (193.986)

Rejected (96.526) 
shows that R \& D spillovers exist from Canada to Japan in all industries except chemical products. (We have conducted the same lest where we set the Japanese spillover parameters equal to zero first. The test gives us identical results as presented in Table 5.3. Therefore. it is independent of the order in which we test the existemie of spillovers.)

The estimates and standard errors for all parankers of the accepted inkkel for each industry are shown in Tables A5.1 - A5.10 in Appendix 10 Chapter 5. The correlation coefricients of the actual chservations and estimated values are listed in liable A5.11 in the Appendix. The model fits the data quite well as the correlation is very high for each industry.

\subsection{Spillover Elasticities}

It is known that $\mathbf{R} \& \mathrm{D}$ spillovers affect production decisions by altering factor demand, production cost, and hence the profitability of spillover receiving industries. In particular, R \& D spillovers exen an important impact on an industry's ability to andertake $R \& D$ activities. In this section, we derive the formulue for the clasticities of factor intensities and average variable cost with respect to spillovers. There are Iwo sets of spillover elasticities; one for domestic spillovers and one for international spillovers.

The spillover elasticities of capital input intensities are denoted by $\varepsilon_{\text {an, }}$. where subscript $k i(i=1)$ indicates physical capital intensity and $(i=2)$ indicates $R \& D$ capilal intensity, subscript $s j(j=1)$ is intranational spillovers and $(j=2)$ is international spillovers. Therefore, $\varepsilon_{k /, s}$ is the elasticity of intranational spillovers on the demand for physical 
capital per unit of output. The spillover elasticities of capital input intensities are ohtained from differentiating equation (3.12) with respect to the spillover variables:

$$
e_{k 1 s 1}=\left(\frac{s_{1}}{k_{1}}\right)\left[\frac{\alpha_{12} \eta_{21}-\alpha_{22} \eta_{11}}{\alpha_{11} \alpha_{22}-\alpha_{12}^{2}}\right] y^{0-1}
$$

$$
\varepsilon_{k 1 \text { s2 }}=\left(\frac{s_{2}}{k_{1}}\right)\left[\frac{\alpha_{12} \eta_{22}-\alpha_{22} \eta_{12}}{\alpha_{11} \alpha_{22}-\alpha_{12}^{2}}\right] y^{\theta-1}
$$

$$
\varepsilon_{k 2 s}=\left(\frac{s_{1}}{k_{2}}\right)\left[\frac{\alpha_{12} \eta_{11}-\alpha_{12} \eta_{21}}{\alpha_{11} \alpha_{22}-\alpha_{12}^{2}}\right] y^{\theta-1}
$$

$$
c_{k 282}=\left(\frac{s_{2}}{k_{2}}\right)\left[\frac{\alpha_{12} \eta_{12}-\alpha_{11} \eta_{22}}{a_{11} \alpha_{22}-\alpha_{12}^{2}}\right] y^{\theta-1}
$$

The elasticities of non-capital or variable input demands are given by $\varepsilon_{1, j,}$, where subscript vi $(i=1)$ is the labour input intensity and $(i=2)$ is the materials or intermediate input intensity. The spillover elasticities of non-capital inputs are derived by differentiating equation (..10) with respect to the spillover variables: 


$$
\begin{aligned}
& c_{v i s 1}=\left(\frac{s_{1}}{v_{i t}}\right)\left[\left(\eta_{11} k_{1}+\eta_{21} k_{2}\right)\right. \\
& +\varepsilon_{k 1=1} \frac{k_{1}}{s_{1}}\left(\varphi_{1}+\left(\alpha_{11} k_{1}+\alpha_{12} k_{2}\right) y^{\theta-1}+\eta_{11} s_{1}+\eta_{12} s_{2}\right) \\
& \left.+\varepsilon_{k 211} \frac{k_{2}}{S_{1}}\left(\varphi_{2}+\left(a_{22} k_{2}+a_{12} k_{1}\right) y^{\theta-1}+\eta_{22} s_{2}+\eta_{21} s_{1}\right)\right] \gamma_{1} \\
& i=1,2 \\
& \varepsilon_{v i s 2}=\left(\frac{s_{2}}{v_{i t}}\right)\left[\left(\eta_{22} k_{2}+\eta_{12} k_{1}\right)\right. \\
& +\varepsilon_{k 162} \frac{k_{1}}{S_{2}}\left(\varphi_{1}+\left(\alpha_{11} k_{1}+\alpha_{12} k_{2}\right) y^{\theta-1}+\eta_{11} s_{1}+\eta_{12} s_{2}\right) \\
& \left.+\varepsilon_{k 282} \frac{k_{2}}{s_{2}}\left(\varphi_{2}+\left(\alpha_{22} k_{2}+a_{12} k_{1}\right) y^{\theta-1}+\eta_{22} s_{2}+\eta_{21} s_{1}\right)\right] \gamma_{i} \\
& i=1,2 \text {. }
\end{aligned}
$$

There are two components to the spillover elasticities of the variable fuctor intensities:

1) the direct effect of spillovers, which is the first term in parentheses inside the square brackets; and 2) the indirect effect of spillovers that come from changes in the capital input intensities.

The elasticities of average variable cost with respect to the spillovers are denoted by $\varepsilon_{\mathrm{f}, \mathrm{w}}$, where subscript $c y$ indicates average variable cost. The elasticities of average variable cost also consist of two parts -- the direct impact of spillovers and the indirect impact through altering ne use of capital inputs. The average variable cost elasticities are obtained from differentiating equation (3.9) with respect to the spillover variables:

$$
\begin{aligned}
\varepsilon_{c y s 1}= & \left(\frac{S_{1}}{c^{v} / y}\right)\left[\left(\eta_{11} k_{1}+\eta_{21} k_{2}\right)\right. \\
& +\varepsilon_{k 1 s 1} \frac{k_{1}}{S_{1}}\left(\varphi_{1}+\left(\alpha_{11} k_{1}+\alpha_{12} k_{2}\right) y^{\theta-1}+\eta_{11} S_{1}+\eta_{12} S_{2}\right) \\
& \left.+\varepsilon_{k 2 s 1} \frac{k_{2}}{S_{1}}\left(\varphi_{2}+\left(\alpha_{22} k_{2}+\alpha_{12} k_{1}\right) y^{\theta-1}+\eta_{22} S_{2}+\eta_{21} s_{1}\right)\right] \mathrm{W}
\end{aligned}
$$




$$
\begin{aligned}
\varepsilon_{c y s 2}= & \left(\frac{S_{2}}{c^{v / y}}\right)\left[\left(\eta_{22} k_{2}+\eta_{12} k_{2}\right)\right. \\
& +\varepsilon_{k 182} \frac{k_{1}}{S_{2}}\left(\varphi_{1}+\left(\alpha_{12} k_{1}+\alpha_{12} k_{2}\right) y^{\theta-1}+\eta_{11} S_{1}+\eta_{12} S_{2}\right) \\
& \left.+\varepsilon_{k 2 \varepsilon 2} \frac{k_{2}}{S_{2}}\left(\varphi_{2}+\left(\alpha_{22} k_{2}+\alpha_{12} k_{1}\right) y^{\theta-1}+\eta_{22} S_{2}+\eta_{21} S_{1}\right)\right] w
\end{aligned}
$$

The direct impact of the spillovers (the first term in parentheses inside the square brackets) reflects changes in labour and intermediate input demands. This effect can be positive, negative or zero. $R \&$ D spillovers can increase production efficiency and hence decrease variable cost. In cudition, $R$ \& $D$ spillovers could increase product demand and hence increase the demand for variable inputs. This has the effec: of directly increasing variable cost. In the latıar case when spillovers cause product quality improvement, we expect revenue to increase so that the revenue gains outweigh the cost increases. Product demand is not explicitly modeled, but because the average variable cost function is conditioned on output, our estimates capture output increases over time from the spillovers.

The combined direct and indirect effects of spillovers on average variable cost can be positive. This is because the effects of spillovers include changes in capital input intensities. For example, when a spillover directly reduces average variable cost, it can entail increases in capital input intensities at the same time. These increases lead to higher cost. The positive indirect effect of the spillover can more than offset its negative direct effect. Hence average variable cost increases as a result.

The spillover elasticities are reported in Tables $5.4-5.13$ where $S 1$ refers to intranational spillovers and S2 usternational spillovers. Consider the chemical products 
industry first. Table 5.4 shows that there are no international spillovers between Canada and Japan. This is the only industry where the international now of knowledge does not generate any effect on the production cost and structure in both countries.

However, the Canadian and Japanese chemical industries are affected hy domestic spillovers. We observe that domestic spillovers exert a direct negative effect on the average variable cost of the Japanese chemical products industry. While the effect is positive in the corresponding Canadian industry. The direct effect (shown in the last row of Tables 5.4 - 5.13) reflects the percentage change in average variable cost when capital factor intensities are fixed. This means that a I percent increase in domestic spillovers directly decreases the average variable cost of the Japanese chemical industry by around 0.005 percent and increases that of the Canadian industry negligibly by $0.0(0) 3$ percent. The sum of the direct and indirect effects on average variable cost (shown in the second to the last row of Tables $5.4-5.13$ ) includes the spillover effect transmitted through the capital intensity changes. This means that a 1 percent increase in $R$ \& $D$ undertaken domestically reduces average variable cost in Japan by 0.04 percent and increases that in Canada by 0.001 percent.

In terms of capital intensity changes, we observe that domestic spillovers and the demand for $\mathbf{R} \&$ D capital in Canada are substitutes. A 1 percent increase in spillovers from within the country reduces Canadian $R \& D$ capital intensity by 0.008 percent. The relationship, however, is complementary in Japan. We observe a 0.77 percent increase in $R$ \& $D$ capital intensity with a I percent increase in Japanese domestic spillovers. Physical capital intensity changes in the same direction as $R \& D$ capital intensity in 
Tahle 5.4

Spillover Elnsticities: Chemical Products Industry

\section{Canada}

\begin{tabular}{|c|c|c|c|}
\hline & Mean & Std. Dev. & Mean \\
\hline Lah./Output & 0.00080 & 0.00028 & \\
\hline Mat./Output & 0.00116 & 0.00032 & \\
\hline Phy.Cap./Output & -0.00123 & 0.00021 & \\
\hline R\&D Cap./Output & -0.00851 & 0.00150 & \\
\hline Avg. Var. Cost & 0.00107 & 0.00030 & \\
\hline Dir. Avg. Var. Cost & 0.00035 & 0.00014 & \\
\hline
\end{tabular}

\section{Japan}

SI

S2

Mean Std. Dev. Mean Sid. Dev.

$\begin{array}{lll}\text { Lab./Output } & -0.00423 & 0.07417 \\ \text { Mat./Output } & -0.04326 & 0.32967 \\ \text { Phy.Cap./Output } & 0.05272 & 0.04283 \\ \text { R\&D Cap./Output } & 0.77237 & 0.17767 \\ \text { Avg. Var. Cost } & -0.04215 & 0.32305 \\ \text { Dir. Avg. Var. Cost } & -0.00514 & 0.14781\end{array}$


Canada and in Japan.

Domestic spillovers increase variable factor intensities in Canada and decrease those in Japan. In addition, the direction of change in all factor intensities and average variable cost associated with domestic spillovers for Canada is identical with Bernstein (1994), though the magnitudes of change are different. We find this consistency of the domestic spillover results for each Canadian industry.

Table 5.5 shows the spillover effects on the electrical products industry. This is one of the three industries where international spillovers exist from Japan to Canada. The direct impact of spillovers from Japan on the average variable cost in Canada is positive: a 1 percent increase in Japanese $R \& D$ capital stock causes Canadian average variable cost to increase by 0.02 percent. Average variable cost in Japan decreases directly, however, by around 0.13 percent due to a 1 percent increase in spillovers from Canada. We see that the total effect on average variable cost leads to an increase of 0,07 percent in Canada and a decrease of 0.08 percent in Japan with a 1 percent increase in foreign spillovers.

In addition, international spillovers reduce capital intensities in both countries. In Canada $\mathrm{R} \& \mathrm{D}$ capital intensity falls by around 0.32 percent, while physical capital intensity decreases by around 1.02 percent. In Japan R \& D capital intensity falls more dramatically; a 1 percent increase in Canadian $R$ \& $D$ capital stock decreases Japanese R \& D capital intensity by around 1.04 percent. Phy sical capilal intensity decreases by 0.25 percent in Japan.

International spillovers increase variable factor intensities in Canada and decrease 
Table 5.5

Spillover Elosticities: Electrical Products

Canada

SI

S2

\begin{tabular}{|c|c|c|c|c|}
\hline & Mean & Std. Dev. & Mean & Std. Dev. \\
\hline L.ab./Output & -0.21954 & 0.07285 & 0.04637 & 0.04019 \\
\hline Mat./Output & -0.62209 & 0.12369 & 0.08860 & 0.07389 \\
\hline Phy.Cap./Output & 4.21955 & 2.67189 & -1.02606 & 1.69216 \\
\hline R\&D Cap./Output & -1.74127 & 0.25250 & -0.32733 & 0.30473 \\
\hline Avg. Var. Cost & -0.50603 & 0.08408 & 0.07076 & 0.05685 \\
\hline Dir. Avg. Var. Cost & -0.49577 & 0.10247 & 0.02689 & 0.01914 \\
\hline
\end{tabular}

Japan

SI

S2

Mean Std. Dev. Mean Std. Dev.

\begin{tabular}{lllll} 
Lab./Output & -0.00114 & 0.02583 & -0.05671 & 0.02316 \\
Mat./Output & -0.00020 & 0.04746 & -0.09600 & 0.04030 \\
Phy.Cap./Output & 0.13968 & 0.12107 & -0.25531 & 0.12271 \\
\hline R\&D Cap./Output & 2.15981 & 1.73966 & -1.04622 & 0.45680 \\
Avg. Var. Cost & -0.00046 & 0.04328 & -0.08674 & 0.03592 \\
Dir. Avg. Var. Cost & 0.08994 & 0.05606 & -0.13558 & 0.04656
\end{tabular}


those in Japan. Notice that in Japan international spillovers lead to decreases in all input intensities. In other words, spillovers from Canada enable the Japanese electrical products industry to attain cost-reductions by using less of all the inputs per unit of cutput.

Intranational spillovers exhibit a stronger impact on the Canadian electrical products industry than international spillovers. Moreover. the domestic spillover effect is significantly larger for Canada than for Japan, except for $\mathbf{R} \& \mathbf{D}$ capital intensity. The direct effect on the average variable cost is negative in Canada. while it is positive for Japan. The total effect, however, is negative for both countries. A 1 percent increase in the domestic knowledge base reduces average variable cost by 0.50 percent in Canada and only negligibly in Japan.

Knowledge borrowed domestically is a substitute for Canadian own $R \& D$ investment. $R$ \& $D$ activity is reduced by 1.74 percent when knowledge acquired from within Canada expands by $I$ percent. Japanese own R \& D is complementary Io domestic spillovers. R \& D capital intensity increases by 2.15 percent as a result. Physical capiaal is a complement to domestic spillovers for both countries. In Canada. the complementarity is especially high. With a $I$ percent expansion in domestic $R$ \& $D$ capital stock, physical capital intensity increases by 4.21 percent. In addition. domestic knowledge expansion lowers the variable factor intensities of both countries.

Table 5.6 shows that, in the food and beverage industry, there are international spillovers. However, the effect of international spillovers from Japan to Canada is smaller than the effect from Canada to Japan. Spillovers that cross national borders cause average variable cost in the two countries to rise both directly and indirectly. A I percent 
Table 5.6

Splllover Elasticities: Food and Bevernge

\section{Canada}

SI

S2

Mean

Lab./Output

Mat./Output

Phy.Cap./Output

R\&D Cap./Output

Avg. Var. Cost

Dir. Avg. Var. Cost
$-0.23264$

$-0.28838$

$-0.15683$

0.97205

$-0.27763$

$-0.28201$
Sid. Dev.

0.11146

0.07736

0.02400

0.08770

0.08375

0.08319

0.05404
Std. Dev.

0.05694

0.05285

0.12529

0.05294

0.05359

0.04893

\section{Japan}

$\mathbf{S 1}$

S2

Mean Std. Dev. Mean Sid. Dev.

Lah./Output

$-0.12667$

0.10988

0.34412

0.04100

Mat./Output

$-0.36993$

0.39225

0.87856

$0.25 i 29$

Phy.Cap./Output

0.19198

0.18019

$-0.43877$

0.16934

RdiD Cap./Output

0.76164

0.28369

$-\mathbf{0 . 8 5 2 7 9}$

0.22348

Avg. Var. Cost

$-0.35575$

0.37522

0.84744

0.23752

Dir. Avg. Var. Cost

$-0.13490$

0.15604

0.46913

0.12774 
increase in Japanese $R$ \& $D$ capital increases Canadian average variable cost directly hy 0.05 percent and by 0.06 percent in total. The same percentage increase in the Canadian R \& D capital leads to a direct increase of 0.46 percent and a total increase of 0.84 percent in Japanese average variable cost. The international spillover effect is negative on both capital input intensities in both countries. When knowledge expands hy I percent in Japan. $R$ \& D capital intensity in Canada decreases by 0.07 percent and physical capital intensity by 0.15 percent. In Japan, $R \& D$ capital intensity decreases by 0.8 .5 percent and physical capital intensity by 0.43 percent in response to the $R \& D$ cxpansion in Canada. However, variable factor intensities increase as a result of international spillovers.

Intranational knowledge spillovers decrease the average variable cost of both countries. A 1 percent increase in domestic $R \& D$ capital entails an average variable cost reduction of 0.27 percent in Canada and 0.35 percent in Japan. Spillovers from domestic sources make the production process of both countries more $R \& D$ intensive. R \& D capital intensity increases by around 0.97 percent in Canada and 0.76 percent in Japan. Physical capital intensity, however, decreases in Canada, whereas it increases in Japan. Variable factor intensities in both countries are reduced because of knowledge flows between domestic industries.

Consider next the fabricated metals industry. We sec in Table 5.7 that there are no spillovers from Japan to Canada. There are, however, spillovers from Canada (o) Japan. Knowledge expansion in Canada reduces the average variable cost of Japan directly. However, the indirect effect that comes from changes in capital inputs is 


\title{
Table 5.7
}

\section{Splllover Elaxticities: Fohricnted Methls Industry \\ Canada}

S1

S2

Mean

Lab./Output

Mat./Outpul

Phy.Cap./Output

R\&D Cap./Outpul

Avg. Var. Cost

Dir. Avg. Var. Cost
0.06109

0.07793

$-0.10639$

2.41010

0.03725

0.07369
Sid. Dev.

0.02005

0.01883

0.02067

0.54408

0.01064

0.05996

\section{Japan}

SI
Std. Dev.

Mean

\author{
Sev.
}


positive such that average variahle cost in Japan actually increases by 0.07 pereent as a result of intemational spillovers. In the Japanese fahricated metals industry. there is a complementary relationship hetween international knowledge inflow and own $R$ D capital. For a 1 percent increase in the inflow of foreign knowledge. the Japanesce industry adds to its R \& D capital stock by 0.06 percent. Physical capital is substituted for spillovers from Canada. As a result. physical capital intensity decreases by around 0.07 percent. International spillovers increase variable factor intensities in Japan. The increase is nore in terms of intermediate inputs than in terms of labxur.

Intranational R \& D spillovers affect Canada and Japan. The direct effect of domestic $\mathbf{R} \& \mathbf{D}$ spillovers on average variable cost is positive in buth countries, whereas the indirect effect through capital intensity changes is negative. A I percent increase in domestic $\mathbf{R} \& \mathrm{D}$ expansion raises average variable cost directly by 0.07 percent in Canada and by 0.15 percent in Japan. Because of the indirect effect of donnestic spillovers, average variable cost increase in Canada is only 0.03 percent in total. The indirect role of spillovers offsets the direct cost-increasing effect so that average variable cost in Japan actually decreases by 0.34 percent.

It should be pointed out that the Canadian fabricated metals industry increases own $R$ \& D investment substantially in response to spillovers from domestic industries. A I percent increase in other industries' knowledge base causes own R \& D capital to expand by 2.41 percent. Own R \& D activity in Japan also increases by arcund 0.73 percent. By contrast, physical capital in Canada and Japan becomes less intensive in the production process as a result of domestic spillovers. The percentage decrease is similar 
in both countries. In addition, variable factor intensities increase in Canada but decrease in Japan due to spillovers from domestic sources.

Table 5.8 summarizes the effect of spillovers on the factor intensities and average variable cost of the non-electrical machinery industry in Canada and Japan. The table shows that there are spillovers from Canada to Japan. but the spillover effect is generally small. The direct cost-reduction from international spillovers is a negligible $\mathbf{0 . 0 0 2}$ percent. The sutall effect of international spillovers is also observed for changes in capital and variable factor intensities.

Donnestic knowledge flows among industries cause production to become more expensive in the Canadian non-electrical machinery industry. while production becomes less costly in Japan. Domestic spillovers increase average variable cost directly by around 0.04 percent in Canada and in Japan it decreases by 0.05 percent. However, through capital intensity changes. average variable cost decreases indirectly in both countries. As a result. average variable cost in Canada increases by less than 0.01 percent. while in Japan it is reduced by 0.21 percent.

In Canada domestic spillovers are complementary to capital and non-capital input demands. We see an increase of 1.14 percent in physical capital intensity from a 1 percent expansion of domestic $R \& D$ capital stock. In terms of $R \& D$ capital intensity. the increase is around 0.41 percent. The increases in variable factor intensities are negligible. In Japan spillovers are complements only to $R \& D$ capital; the intensity increases by 0.32 percent. Physical capital and variable factor inputs in Japan are substitutable for donestic spillovers: the elasticity is around 0.2 percent for each of these 
Table 5.8

Spillover Elasticities: Non-etectrical Machinery Industry

Conada

SI

Lab./Output

Mat./Output

Phy.Cap./Output

R\&D Cap/Output

Avg. Var. Cost

Dir. Avg. Var. Cost
Mean

Sid. Dev.

0.03311

0.00589

0.00722

1.14751

0.415 .56

0.00678

$\mathbf{0 . 0 8 6 2 4}$
$\$ 2$

Mean

Sild. IXev.

\section{Japan}

Mean

$-0.18996$

$-\mathbf{0 . 2 2 2 8 0}$

$-0.17351$

0.32097

$-0.21361$

$-0.05282$
Sid. Dev.

0.15810

0.18714

0.14467

0.20133

0.17934

$0 .(60034$
Mean

(0.(0)109

(1.)(x)12K

$0.0(x \times) 1$

0.036 .57

()$.(x) 123$

$-(0 .(x))$ i4
Std. Irev.

(I.(X) I I

().(x)1.31

().(X)269

(1.01 179

(1.)(x) 26

(1)(x)12:- 

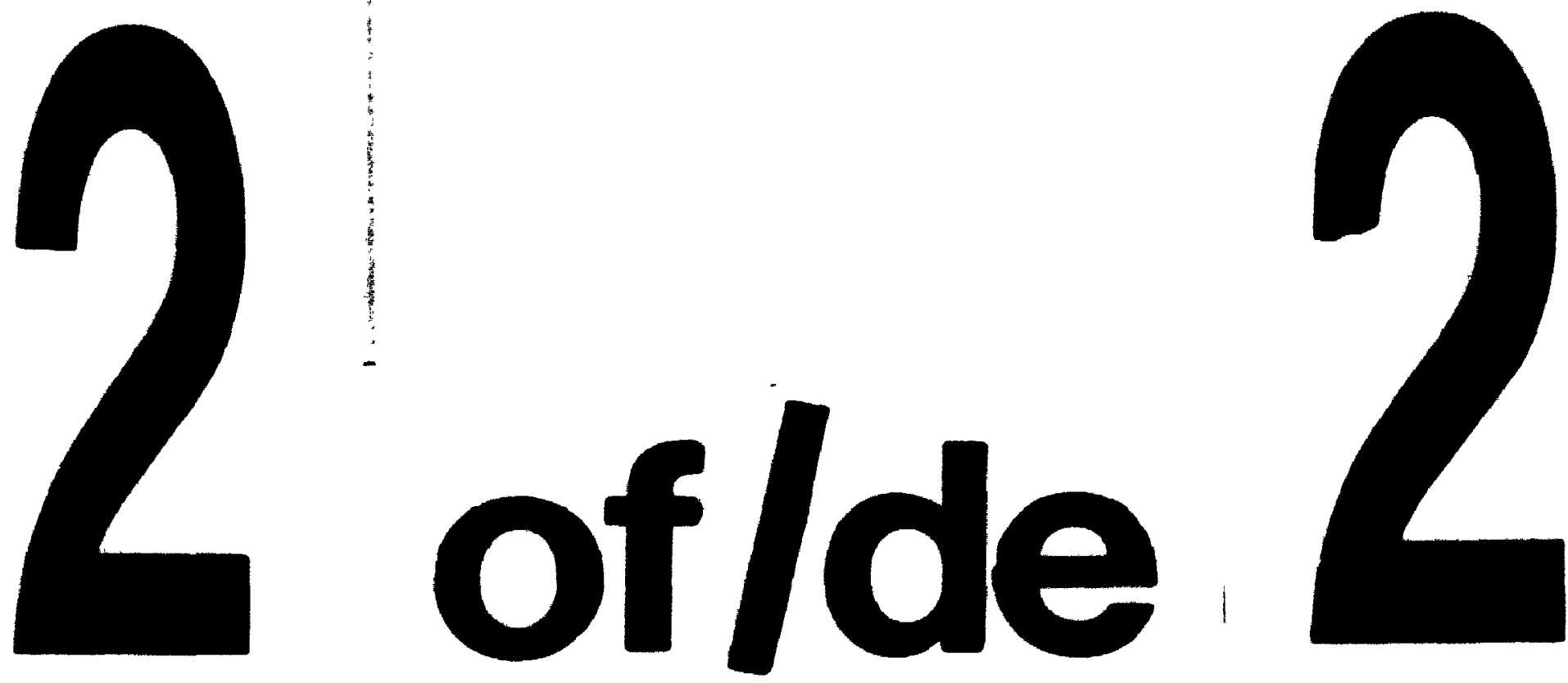

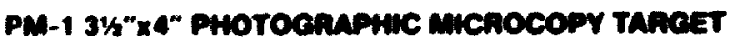
wos 10 ro Amatreo we EoumALENT

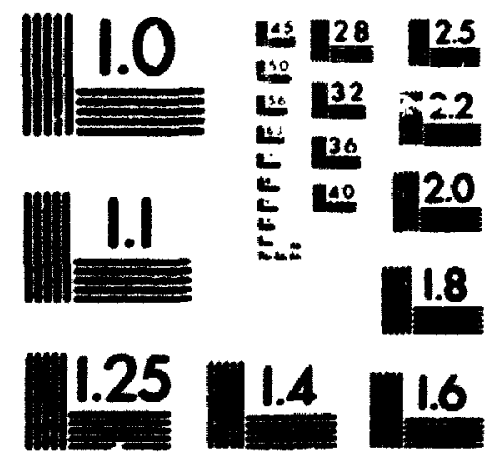

Precricasm hesoumon taneats 
inputs.

Table 5.9 shows that the international knowledge flow from Camadia exerts a direct positive impact on the average variable cost of the Japanese non-metallic mineral products industry. The percentage increase in average variable cost is 0.24 percent in total with a I percent $R$ \& $D$ capital expansion in Canada. There is a substitutability between international spillovers and R \& D capital input intensity: the relevant spillover elasticity is 1.30 percent. In terms of physical capital, the factor intensity is increased by (0.(K) percent. Variable factor demands are complementary to international $R \& D$ capital inflows.

Domestic spillovers affect the Canadian and Japanese non-metallic industry in an opposite way except for R \& D capital. Production cost rises in Canada and falls in Japan. Physical capital and non-capital factor intensities increase in Canada and decrease in Japan. Domestic spillovers are complements to $R \& D$ capital in both countries; the Canadian R \& D capital intensity increases by 1.72 percent and the Japanese intensity increases by around 1.06 percent.

Table 5.10 lists the spillover elasticities for the paper and allied products industry. International spillovers decrease the average variable cost of the Japanese industry by around 0.46 percent, of whish 93 percent results directly from international spillovers. Knowledge transmission from abroad leads to a higher $R$ \& D capital iniensity in the Japanese production. A 1 percent increase in knowledge transmitted from Canada increases the $R \& D$ capital intensity by 1.76 percent. Physical capital is also a complement to isternational spillovers, as its intensity increases by $(0.24$ percent. Variable 
Table 5.9

Spillover Elasticities: Non-metallic Mineral Products Industry

Canada

\begin{tabular}{|c|c|c|c|c|}
\hline & \multicolumn{2}{|c|}{ SI } & \multicolumn{2}{|c|}{$\mathbf{S 2}$} \\
\hline & Mean & Sid. Dev. & Mean & Std. Dev. \\
\hline Lab./Output & 0.07737 & 0.02320 & & \\
\hline Mat./Output & 0.09977 & 0.01835 & & \\
\hline Phy.Cap./Output & 0.17680 & 0.04918 & & \\
\hline R\&D Cap./Output & 1.72343 & 0.17506 & & \\
\hline Avg. Var. Cost & 0.09197 & 0.01971 & & \\
\hline Dir. Avg. Var. Cost & 0.16823 & 0.02788 & & \\
\hline
\end{tabular}

Japan

SI

S2

Mean Std. Dev. Mean Std. Dev.

$\begin{array}{lllll}\text { I.ab./Output } & -0.21254 & 0.31547 & 0.09284 & 0.09748 \\ \text { Mat./Output } & -0.64077 & 1.10615 & 0.26566 & 0.34355 \\ \text { Phy. Cap./Output } & -0.04117 & 0.03719 & 0.09436 & 0.04378 \\ \text { R\&D Cap./Output } & 1.06019 & 0.50572 & -1.30794 & 0.69161 \\ \text { Avg. Var. Cost } & -0.58272 & 0.99439 & 0.24238 & 0.30907 \\ \text { Dir. Avg. Var. Cost } & -0.23635 & 0.43225 & 0.11944 & 0.15318\end{array}$


Table $\mathbf{5 . 1 0}$

Spillover Elasticities: Paper \& Allied Products Industry.

Canada

S1

S2

Mean

Sid. Dev.

Mean

Std. Dev.

Lab./Output

0.00129

0.00020

Mat./Output

0.00192

0.00029

Phy.Cap./Output

$-0.01220$

0.00263

R\&D Cap./Output

0.01819

0.00367

Avg. Var. Cost

0.00174

0.00027

Dir. Avg. Var. Cost

0.03267

0.00814

Japan

S।

S2

Mean

Std. Dev.

Mean

Std. Dev.

Lab./Output

$-0.02612$

0.01933

$-0.23963$

0.03367

Mat./Output

$-0.05352$

0.04015

$-0.48981$

0.07113

Phy Cap./Output

$-0.05023$

0.04249

0.24047

0.02246

R\&D Cap./Output

0.68332

0.21436

1.76238

0.83748

Avg. Var. Cost

$-0.05106$

0.03868

$-0.46418$

0.06376

Dir. Avg. Var. Cost

0.06417

0.16080

$-0.43548$

0.05814 
factor inputs, however, are substitutes for international spillovers.

The domestic spillover effect is generally small in Canada compared with that in Japan. Domestic spillovers exert a direct positive impact on the average variable cost of the Canadian and Japanese industry. [rue to the indirect effect through capital intensity changes of domestic spillovers, the average variabie cost increases by only 0.001 percent in Canada, but the Japanese average variable cost decreases by 0.05 percent. While the domestic spillover impact in Japan is larger than that in Canada, it is substantially smaller than that of foreign spillovers on the Japanese average variable cost. This is also true for factor intensity changes, though the direction of change varies between the two countries. R \& D capital intensity increases in both Canadian and Japanese paper and allied products industry, while physical capital intensity falls. In terms of variable factor intensity changes, the two countries react in an opposite way; the relevant intensities increase in Canada and decrease in Japan due to domestic knowledge expansion.

Table 5.11 shows that average variable cost in the Japanese petroleum industry decreases directly by around 0.14 percent with increases in knowledge borrowed from Canada. The combined cost effect, however. leads to a substantial increase of around 2.38 percent. Note that we also observe much more drastic increases than in other industries with respect to $R \& D$ capital and variable input intensities. International spillovers cause $R$ \& D capital intensity to increase by 4.8 percent. With respect to nonR \& D inputs, international spillovers increase physical capital intensity by 0.24 percent, labour input intensity by 3.12 percent and intermediate input intensity by 2.35 percent. Obviously. spillovers from Canada entail substantial increases in all input intensities such 
Table 5.11

Spillover Elasticities: Petroleum Products Industry

Canada

Si

$\$ 2$

Mean

Sid. Dev.

Mean

Sitd. Ixev.

Lab./Output

Mat./Output

Phy. Cap./Output

R\&D Cap./Output

Avg. Var. Cost

Dir. Avg. Var. Cost
$-0.36114$

$-0.387 .36$

$-0.01436$

0.28536

$-\mathbf{0 . 3 8 5 9 2}$

$-0.06201$
0.12828

0.13985

0.00206

0.03514

0.13948

0.02038

\section{Japan}

SI

S2

Mean Std. Dev. Mean Sid. Dev.

2.50875

1.73831

3.12722

1.49562

1.89200

1.34152

2.353(1)2

1.19173

0.19314

0.18984

0.24917

$0.0 \times 1 \times 14$

0.28995

0.44849

$4.807(0)$

3.22323

1.91676

1.35740

2.38292

$1.21 \times 156$

0.08978

0.05520

$-0.142(0)$

().05300 
that production cost increases as more inputs are used per unit of output.

With respect to domestic spillovers, the Japanese petroleum products industry exhibils larger elasticities (in absolute value) compared to those of Canadian domestic spillovers. Domestic knowledge spillovers decrease Canadian average variable cost by 0.3K percent. hut lead to cost increases in Japan by 1.91 percent. Note that the cost increase in Japan is almost as large as that brought about by foreign spillovers. In addition. just as for international spillovers, the cost increase due to domestic spillovers is associated with increases in all input intensities.

In the Canadian petroleum products industry, $R \& D$ capital intensity increases by 0.28 percent. as domestic knowledge expands by 1 percent. Non-R \& $D$ capital and variable factor intensities fall with domestic spillovers.

Tahle 5.12 shows that. in the primary metals industry, there are international spillovers between Canada and Japan. This is the third industry where intemational flows of knowledge generate effects in Canada as well as in Japan. We observe for both countries cost reductions associated with foreign spillovers. Moreover, own $\mathbf{R} \& \mathbf{D}$ capital is a strong complement to international spillovers in Canada and in Japan. A I percent increase in Japanese $\mathbf{R} \& \mathbf{D}$ capital stock leads to an increase in:Canadian $\mathbf{R} \&$ D capital intensity by 2.03 percent. The same percentage increase in spillovers from Canada causes Japanese $R \& D$ capital intensity to increase by 3.26 percent. In Canada. international spillovers are substitutes for all non-R \& $D$ inputs. In Japan, physical capital is complenxentary to spillovers from foreign sources, while variable inputs are substitutes.

Domestic spillovers affect the Canadian industry more than the Japanese 
Table $\mathbf{5 . 1 2}$

\section{Spillover Elasticities: Primary Metnls Industry}

Canada

SI

$$
\text { Mean }
$$

Lab./Output

Mat/Output

Phy. Cap./Output

R\&D Cap/Output

Avg. Var. Cost

Dir. Avg. Var. Cost
0.33515

0.46468

$-0.03579$

$-1.71153$

0.43395

0.14213
Sid. Dev.

0.09280

0.06568

0.00716

1.43843

0.06297

0.03046
S2

Mean

Sid. Dev.

$-0.07235$

0.05907

0.06192

0.05442

$-0.06981$

2.03228

$1.8920 K$

$-0.08601$

0.60 .33

$-0.02544$

$0.016 \times 1$

\section{Japan}

S1
$\$ 2$

Mean Sid. Dev. Mean Sid. Dev.

Lab./Output

0.02308

0.03425

$-0.68348$

0.22889

Mat./Output

0.03415

0.06135

$-1.08059$

0.44603

Phy.Cap./Output

$\mathbf{- 0 . 0 9 2 4 3}$

0.08132

0.37989

0.05503

R\&D Cap./Output

0.57247

0.23624

3.26442

1.06945

Avg. Var. Cost

0.03166

0.05488

$-0.98718$

0.390009

Dir. Avg. Var. Cost

0.02231

$-0.46688$

0.18078 
counterpart. Domestic spillovers increase average variable cost by 0.43 percent in Canada and in Japan by 0.03 percent. Canadian domestic spillovers decrease capital factor intensities and increase non-capital factor intensities. In Japan, domestic spillovers increase all factor intensities except that of physical capital.

Table 5.13 shows the spillover effect in the transportation equipment industry. We see that the average variable cost of the Japanese indust-v decreases by 0.02 percent when the industry acquires knowledge from Canada. Japanese own R \& D capital is affected relatively more by international spillovers, compared to the other factor intensities. With a 1 percent increase in knowledge borrowed internationally, there is a 0.24 percent increment to own R \& D capital. Physical capital intensity also increases, but not as much as R \& D capital intensity. By contrast. international spillovers make Japanese production less intensive in non-capital input use.

In Canada. domestic spiliovers lead to decreases in all factor intensities as well as average variable cost of production. Average variable cost decreases by 0.86 percent. In Japan domestic spillovers cause all variables to change in the same direction as international spillovers. However, domestic spillover elasticities on both capital intensities are substantially larger than those obtained for international spillovers.

\subsection{Summary}

In summary, the test results and the spillover elasticities show us a number of important findings. International spillovers from Japan do not exist in the Canadian chemical products. fabricated metals, non-electrical machinery, non-metallic mineral 
Table 5.13

Spillover Flasticities: Transportntion Eouloment Industry

Canada

SI

$\$ 2$

Mean

Sid. Dev. Mean

Sid. Ixev.

Lab./outpùt

$-0.72535$

0.35126

Mat./Output

$-0.90874$

0.2890 .3

Phy.Cap./Output

$-0.09146$

0.01804

R\&D Cap./Output

$-0.11098$

0.02107

Avg. Var. Cost

$-\mathbf{0 . 8 6 5 8 6}$

0.30112

Dir. Avg. Var. Cost

$-0.08720$

0.02822

\section{Japan}

SI

Std. Dev.

Mean

$-0.0 \times 969$

$-0.02364$

0.03074

0.24772

$-0.02312$

0.02720

Avg. Var. Cost

$-0.02101$

\$2

Sid. Dev.

$0.010 \times 07$

0.02785

0.06492

0.06805

Dir. Avg. Var. Cost
$-0.03358$

0.13550

0.12295

0.16781

$-0.01827$
$-0.0210$ 
products, paper and allied products, petroleum products, primary metals and transportation equipment industries. The Canadian electrical products, food and beverage and primary metals industries are shown to be users of spillovers originating from Japan. However. even in these three industries, the domestic spillover effects dominate the international spillovers from Japan. In addition, we can recall that food and beverage industry is at the margin of rejection for the chosen critical values. Next, international spillovers from Canada are found to affect all the Japanese industries except chemical products. In Japan, as for Canada, domestic spillovers dominate their foreign counterparts.

These results are not surprising. Even though Japan is Canada's second largest trading partner, we observe a rather weak trade link, as only $6 \%$ of Canadian exports and imports are accounted for by trade with Japan. The results, along with Bernstein (1994), show that foreign spillovers in Canada are dominated by those emanating from the U.S. Moreover. the strong relationship between the U.S. and Canadian R \& D capital stocks suggests that there is a North American technological link to Japan. However, this link is not as strong as the domestic links found in Japan.

International spillovers generally decrease average variable cost, as seven Japanese industries attain cost reductions directly from the $R \& D$ expansion in Canada. Direct average variable cost reductions in Japan associated with a 1 percent increase in Canadian R \& D capital are: 0.13 percent for electrical products, 0.04 percent for fabricated metals, 0.001 percent for non-electrical machinery, 0.43 percent for paper and allied products. 0.14 percent for petroleum products, 0.46 percent for primary metals and 0.02 percent for Iransportation equipment. These elasticities are new to the literature. Moreover, these 
numbers are generally smaller than those obained hy Bemstein (1994) for Canadian industries affected by spillovers from the U.S. The elasticities are also smaller than the average obtained by Mohnen (1990) for five Canadian industries with spillovers from major OECD countries.

Domestic and foreign spillovers generally affect $R \& D$ capital intensily relatively more than other factor intensities. Moreover, intemational spillovers from Canada increase $\mathbf{R} \& \mathbf{D}$ capital intensity in the Japanese fabricated metals. mon-electrical machinery, paper and allied products. petroleum products, primary metals and transportation equipment industries. Increases across industries range from 0.03 percem to 4.80 percent. Intermational spillovers decrease $R$ D capital intensily in the ther three Japanese industries; namely, electrical products, food and beverage and non-metallic mineral products. The range is from 0.85 percent to 1.30 percent. Japanese domestic spillovers increase $R \& D$ capital intensity in every industry. The range is from 0.28 percent to 2.15 percent. Therefore, domestic spillovers are a strong complement to Japanese own R \& D. Canadian domestic spillovers increase R \& D capital intensity in food and beverage, fabricated metals, non-electrical machinery, non-metallic mineral products, paper and allied products and petroleum products and decrease that in the other four industries. The increase in $R \& D$ capital intensity ranges from 0.01 percen! 102.41 percent; the decrease is between 0.01 percent and 1.74 percent. The decrease in $R \& D$ capital intensity is found in Bemstein (1988) as well.

With respect to other factor intensities, it is found that physical capital intensity can increase or decrease in response to intranational and intemational spillovers. In 
Japan, international spillovers lead to increases in physical capital intensity in six industries and domestic spillovers increase it in a different set of five industries. International spillovers increase physical capital intensity between 0.01 percent and 0.37 percent, while the range is from 0.05 percent to 0.20 percent with domestic spillovers. Domestic spillovers in Canada decrease physical capital intensity in seven industries by hetween 0.001 percent and 0.15 percent. However, in the three industries where physical capital intensity increases: namely, electrical products, non-electrical machinery and nonmetallic mineral products, the effects are quite large. The elasticities are 4.21 percent. 1.14 percent and 0.17 percent respectively. These results are consistent with Bernstein (1988) where interindustry spillovers are complements to the demand for physical capital in industries with relatively larger propensity to spend on $R \& D$, but are substitutes for the other industries. The complementarity between interindustry spillovers and the demand for physical capital is also found in Bernstein and Nadiri (1988) for the U.S. industries.

Labour and intermediate input intensities always respond in the same way. In Japan. domestic spillovers result in lower variable factor intensities in eight industries. In Canada, domestic spillovers reduce variable factor intensities in four industries. However. in the other six industries the increases in variable factor intensities are quite small. Similar results are found in Bernstein (1988) for Canada, Bernstein and Nadiri (1988) for the U.S. and Suzuki (1993) for Japan. 
97

APPENDIX

TO CHAPTER 5 
Table A5.1

Estimates for Chemleal Products Industry

LOG OF LIKELIHOOD FUNCTION $=408.908$

Parameler

BIC

BIJ

bII

OC

e]

$\boldsymbol{\varphi I C}$

QIJ

$\varphi 2 C$

甲2)

al1

$\boldsymbol{\alpha 2 2}$

$\boldsymbol{\lambda}$

nIIC

nIIJ

n22C

n22J

n12C

712J

n2,

721J

B2C

B2)
Estimate

1.52176

$-.252428$

.964558

.832365

$-2.61253$

$-3.14997$

.652656

1.36157

1.37959

.978193

$-.531061$

.00009
Standard

Error

.64364

.20493

.22148

.04042

1.21495

1.50256

.45294

.73988

.86152

.66070

.26780

.00003
.00000

$-.00016$

5.55076

7.97661
.00001

.00005

2.46713

3.06498 
Table A5.2

\section{Estimates for Electrical Products Industry \\ LOG OF LIKELIHOOD FUNCTION $=\mathbf{3 4 4 . 5 2 0}$}

Parameter

BIC

BIJ

bII

OC

OJ

$\varphi 1 C$

Q1J

$\varphi 2 C$

甲2J

all

$\boldsymbol{\alpha 2 2}$

$\boldsymbol{\lambda}$

nIIC

nIIJ

n22C

n22J

$\eta 12 C$

n12J

$\eta 21 \mathrm{C}$

П21J

B2C

B2J
Estimate

.63770

.37254

.25637

$-2.46879$

.04287

.64903

15.13190

5.48923

$-.10039$

.00036

.00001

.00041

.00012

$-.00055$

$-.00015$

$-.00026$

.78868

1.57230
Standard

Error

.02961

.06691

.04549

1.81937

.35378

.90613

7.28761

2.15629

.03993

.00010

.00007

.00018

.00007

.00021

.00005

.00008

.05119

.19753 
Table A5.3

Estimates for Food \& Beverages Industry
LOG OF LIKELIHOOD FUNCTION $=683.869$

Parameter

BIC

BIJ

b1

oc

(6)

$\varphi \mid C$

(PIJ

$\varphi 2 C$

(P2J

a 11

$\alpha 22$

$\lambda$

nIIC

nIIJ

ท22C

n22J

712C

$\eta \mid 2 J$

n21C

1213

B2C

B23
Estimate

.19863

.05911

.45934

.92412

$-5.72525$

$-1.06864$

$-8.16139$

13.98580

131.82200

.00486

$-.00011$

$-.00005$

.00343

.00886

.00221

.00368

$-.00029$

$-.00066$

.883324

1.83130
Standard Error .02033 .06308 .04249

.03897

3.03178

1.18101

8.15268

9.23698

172.03100

.00651

.00006

.00007

.00497

.00839

.00145

.00248

.00030

.00058

.114576

.735657 
Table A5.4

\section{Estimates for Fabricated Metals Industry \\ LOG OF LIKELIHOOD FUNCTION $=521.516$}

Parameter

BIC

BIJ

bII

$\theta C$

开

$\varphi \mid C$

$\varphi 1 J$

$\varphi 2 C$

甲2J

$\alpha \mid 1$

$\alpha 22$

$\lambda$

nIIC

nIIJ

n22C

n22J

n12C

$\eta 12 \mathrm{~J}$

n21C

721J

B2C

B2J
Estimate

1.59561

$-.67931$

$-1.02534$

.84777

.93911

2.25163

1.72995

$-2.15712$

3.58493

62.83640

.01352

$-.00000$

.00001

$-.00040$

.00082

$-.00049$

3.11595

2.22244
.00077

1.21088

Standard

Error

.61139

.25376

.15736

.03289

.03395

2.09328

0.25576

1.24265

2.75511

10.18960

.02564

.00008

.00004

.00201

.00073

.67523 
Table A5.5

Estimates for Non-electrical Machinery Industry

LOG OF LIKELIHOOD FUNCTION $=439.091$

Parameter

BIC

BIJ

b|

QC

$\boldsymbol{\theta J}$

$\varphi \mid C$

$\varphi \mid J$

$\varphi 2 C$

\$2J

$\alpha \mid 1$

$\boldsymbol{\alpha 2 2}$

$\lambda$

nIIC

nIIJ

n22C

ท22J

$\eta 12 C$

$\eta 12 J$

nic

n21J

B2C

B2J
Estimate

.209586

.23226

.08908

1.06627

$-1.10018$

$-1.55439$

.07457

1.06214

6.22177

41.49210

$-.03287$

.00005

$-.00008$

.00000

$-.00011$

.35660

.63150
.00014

.12247

Standard

Error

.06782

.07460

.20080

.03417

.91088

|.7188!

1.20432

0.52628

0.86186

18.18760

.02838

.00009

.00003

.00023

.21659 
Table A5.6

\section{Estimates for Non-metallic Products Industry \\ LOG OF LIKELIHOOD FUNCTION $=\mathbf{4 6 0 . 2 5 2}$}

Parameter

BIC

BIJ

bll

$\theta \mathrm{C}$

өJ

$\varphi$ IC

Q1J

$\varphi 2 C$

$\varphi 2 J$

all

$\alpha 22$

$\lambda$

nIIC

n11J

n22C

ท22J

n12C

n12J

n2IC

T21J

B2C

[2J
Estimate

2.67351

2.14527

$-1.21708$

.79171

.69710

$-2.29927$

.12090

$-\mathbf{3 . 0 6 2 6 7}$

.72057

3.05347

.13415

.00003

.00002

.00383

.00010

$-.00020$

$-.00038$

5.31290

15.16550
.00181

Standard Error

1.41966

1.57357

.20079

.05571

.07077

1.04752

.94442

1.76601

.53544

1.97।27

.14979

.00002

.00004

.00057

.00010

.00022

2.99107

9.07023 
Table A5.7

Fotimates for Paper a Allied Products Industry

LOG OF LIKELIHOOD FUNCTION $=481.817$

Parameter

BIC

BIJ

bII

ec.

(J)

$\boldsymbol{\varphi} \mid \mathbf{C}$

$\varphi$ IJ

$\varphi 2 C$

$\varphi 2 J$

aII

$\propto 22$

$\lambda$

nIIC

7II

n22C

n22J

$\eta 12 C$

n12J

n21C

n21J

B2C

B2J
Estimate

.66541

.15757

.06088

$-4.52815$

2.74888

$-1.16333$

$-2.49594$

7.44908

28.98840

$-.02662$

$-.00045$

$-.00002$

.00007

.00012

$-.00089$

.00036

Standard Error .23033

.05445

.30183

4.25775

2.03822

4.83730

4.69299

.04346

.00001

.00001

.

1.55669

.61215

1.53704 
Table A5.8

Estimates for Petroleum and Products Industry LOG OF LIKELIHOOD FUNCTION $=616.619$

Parameter

BIC

B1J

b11

6C

由J

$\varphi 1 C$

QIJ

甲2C

甲2J

all

$\propto 22$

$\lambda$

n11C

nIIJ

ท22C

n22J

n12C

त12J

n21C

721J

B2C

B2J
Estimate

.01370

.00197

.01014

1.15307

$-6.96194$

$-2.29660$

$-.87303$

.89144

177.79500

69.75880

$-.00077$

$-.00001$

.00006

$-.00055$

$-.00017$

$-.00003$

$-.00001$

.35457

.05146
.00074

.00159

Standard Error .00949 .03187 .07038

2.73397

2.24513

.83102

1.27888

165.26900

109.22800

.00201

.000104

.00016

.00003

.00008

.24457

.03910 .00298 
Table A5.9

Estimates for Primary Metals Industry

LOG OF LIKELIHOOD FUNCTION $=\mathbf{4 8 0 . 7 4 2}$

Parameter

BIC

BIJ

b11

ec

$\boldsymbol{\theta J}$

$\varphi \mid C$

$\varphi \mid J$

$\varphi 2 C$

甲2J

aII

$\alpha 22$

$\boldsymbol{\lambda}$

nIIC

nIIJ

ท22C

n22J

n12C

n12J

n21C

n2IJ

B2C

82J
Estimate

2.27675

9.73519

1.99157

.76795

.69944

$-2.63103$

$-1.12390$

.71277

.56195

.11873

.22211

.00006

$-.00021$

$-.00038$

.00001

$-.00052$

.00008

$-.00005$

9.03944

35.22300
Standard Error

1.31574

8.98476

.40552

.05368

.08066

4.70846

.67409

1.88181

.57016

.07358

1.80807

.00004

.00014

.00072

.00001

.00036

.00006

.00006

$\mathbf{5 . 6 2 3 4 2}$

36.08390 
Table A5.10

Estimates for Transportation Equipment Industry LOG OF LIKELIHOOD FUNCTION $=520.803$

Parameter

BIC

B1J

bl1

OC

日J

甲IC

pIJ

$\varphi 2 \mathrm{C}$

甲2J

Q11

$\alpha 22$

$\lambda$

ทIIC

nIIJ

ท22C

n22J

712C

n12J

n21C

ท21J

B2C

B2J
Estimate

.12690

.06908

$-.25308$

1.11204

$-2.26288$

$-\mathbf{5 . 7 3 6 5 2}$

.62768

7.76627

19.58540

159.85600

$-.00974$

$-.00001$

.00016

$-.00097$

.00006

.39282

1.89822
.00046

.26594

Standard

Error

.08585

.04254

.09397

.07802

1.66867

6.45105

1.73617

8.90583

23.27380

164.42300

.01002

.00001

.00011

.00077

.92259 
Table A5.11

\section{Correlation of Actual and Fitted Values}

Industry

Labour Interm. Phy. Cap. R\&D Cap. Variable Demand Demand Demand Demand Cost

$\begin{array}{llllll}\text { Chemical Products } & 0.96 & 0.98 & 0.95 & 0.89 & 0.99 \\ \text { Electrical Products } & 0.86 & 0.99 & 0.97 & 0.97 & 0.99 \\ \text { Food \& Beverages } & 0.99 & 0.99 & 0.95 & 0.99 & 0.99 \\ \text { Fabricated Metals } & 0.99 & 0.99 & 0.76 & 0.97 & 0.99 \\ \text { Machinery } & 0.96 & 0.99 & 0.96 & 0.95 & 0.99 \\ \text { Non-metallic Prodcuts } & 0.99 & 0.90 & 0.87 & 0.96 & 0.99 \\ \text { Paper \& Allied Products } & 0.97 & 0.99 & 0.98 & 0.90 & 0.99 \\ \text { Petroleum Products } & 0.96 & 0.99 & 0.97 & 0.94 & 0.99 \\ \text { Primary Metals } & 0.99 & 0.98 & 0.86 & 0.87 & 0.99 \\ \text { Transportation Equ:pment } 0.99 & 0.99 & 0.96 & 0.97 & 0.99\end{array}$




\section{REFERENCES}

Bernstein. J.I. (1994). "R \& D Spillovers Between U.S. and Canadian Industries". Forthcoming Canadian Jourmal of Economics. Papers and Proceedings.

Bernstein. J.I. (1989), "The Structure of Canadian Industrial R \& D Spillovers and the Rates of Retum to R \& D". Jourmal of Industrial Ecomomics, 37(3). pp. 31.5328.

Bernstein, J.I. (1988), "Costs of Production. Intraindustry and Interindustry R \& D Spillovers: Canadian Evidence". Canadian Jourmal of Economics. 21(2), pp. 324347.

Bernstein J.I. and M.I. Nadiri (1988), "Interindustry R D Spillovers. Rales of Return, and Production in High-Tech Industries". American Ecomomic Revirw. May, pp. 429-434.

Mohnen, P. (1990), "Relationship between R \& D and Productivity Growth in Canada and Other Major Industrialized Countries", Centre de rechenche sur les politiquses Economiques. Université du Québec a Montréal.

Goto, A and K. Suzuki (1989), "R \& D Capital, Rate of Retum on R \& D Invesiment and Spillover of $\mathbf{R}$ \& $\mathrm{D}$ in Japanese Manufacturing Industries". The Review of Economics and Statistics, Vol.. LXXI, No.4, November, pp. 555-564.

Suzuki, K. (1993), "R \& D Spillovers and Technology Transfer Among and Within Vertical Keiretsu Groups", Intermational Joumal of Industrial Organization, Vol.II 1993. pp. 573-591. 


\section{CHAPTER 6 TOTAL FACTOR PRODUCTIVITY GROWTH AND SOCIAL RATES OF RETURN}

\section{I Introduction}

Total factor productivity (TFP) growth is a measure of dynamic production efficiency. It measures the residual growth of output over input. TFP growth results from non-constant returns to scale and technological change. $R \& D$ spillovers affect the rate of technological change and thereby TFP growth. In this model there are two sources of $R$ \& D spillovers: a domestic and a foreign source. In this chapter, we investigate the contribution of intranational and internutional R \& D spillovers to TFP growth of Canadian and Japanese manufacturing industries.

The existence of spillovers creates a wedge between the social and privale rates of return to $R$ \& $D$. The privale rate of retum measures the return from the performance of $K \& D$, while the social rate of retum is the return from the use of $R \& D$. The latter includes the return associated with spillovers, because $\mathbf{R} \& \mathrm{D}$ can benefit many users other than the $R \& D$ performing producer. In this chapter, we are interested in determining the social rate of return to $R \& D$ capital in the Canadian and Japanese industries. The social rate of return in this study consists of three elements; the private rate of return and the returns associated with domestic and international spillovers. Specifically, we want to determine the relative importance of domestic and foreign spillovers in contributing to the social rate of retum to $R \& D$ in the relevant industries.

The chapter is organized in the following way. Section 2 outlines the measure and decomposition of TFP growth for the Canadian and Japanese industries. In Section 3, the 
social rate of retum to $R \& D$ is defined and the respective rates for the Canalian and Japanese industries are presented. Section 4 is the summary of this chapter.

\subsection{Decomposition of Total Factor Productivity Growth}

TFP growth rate is the residual of output over input growth rates, and is the result of technological change and non-constant retums to scale. R \& D spillovers causc changes in technology and hence affect TFP growth. Bernstein (1994) and Mohnen (1990) show how TFP growth is affected by $R \& D$ spillovers. In this chapter. TFP growth is decomposed into scale and technological change effects. and the latter comsists of intranational and intemational $\mathbf{R} \& \mathbf{D}$ spillovers.

TFP growth is defined in discrete time as utput growth minus input growth:

$$
\operatorname{TFPG}(0,1)=\left(y_{1}-y_{0}\right) / y_{m}-s_{n}^{T}\left(v_{1}-v_{0}\right) / v_{m}-s_{k m}^{T}\left(K_{1}-K_{0}\right) / K_{m}
$$

where subscript I represents the current period, subscript 0 represents the past period, subscript $m$ designates the mean value of a variable (for example. $\left.y_{m}=0.5\left(y_{1}+y_{0}\right)\right), s_{1 m}$ is the vector of non-capital cost shares, which are defined as $w_{m m} v_{i m} /(c / y)_{m} v_{m}(i=1.2), s_{m m}$ is the vector of capital cost shares, which are defined as $\omega_{1 m} K_{k} \mu(c / v)_{m} v_{m}(k=1,2)$.

TFP growth rates can be decomposed using the variable cost function specifted in Chapter 3. Since the variable cost function is a second onder quadratic form in which second onder parameters are constant over time, then variable cost differences can be decomposed into: 


$$
\begin{aligned}
& c_{1}^{v}-c_{0}^{v}=0.5\left[\Sigma_{1=1,2}\left(v_{i 1}+v_{10}\right)\left(w_{11}-w_{10}\right)\right. \\
& +\left(\left(\partial c^{v} / \partial y\right)_{1}+\left(\partial c^{v} / \partial y\right)_{0}\right)\left(y_{1}-y_{0}\right) \\
& +\Sigma_{k=1.2}\left(\left(\partial c^{v} / \partial K_{k}\right)_{2}+\left(\partial c^{v} / \partial K_{k}\right)_{0}\right)\left(K_{k z}-K_{k 0}\right) \\
& \left.+\Sigma \Sigma_{e=1,2}\left(\left(\partial c^{v} / \partial S_{s}\right)_{1}+\left(\partial c^{v} / \partial S_{e}\right)_{0}\right)\left(S_{e 1}-S_{s 0}\right)\right] \text {. }
\end{aligned}
$$

By definition, $c_{1}^{v}-c_{i}^{v}=\Sigma_{i=1,2}\left[w_{11}\left(v_{12}-v_{10}\right)+v_{10}\left(w_{11}-w_{i 0}\right)\right]$, and substituting this derinition into equation (6.2) and moving the first term of equation (6.2) to the left-hand side, we obtain the left-hand side (LHS) to be:

$$
\begin{aligned}
L H S= & \Sigma_{i=1,2}\left[w_{11}\left(v_{i 1}-v_{i 0}\right)+v_{i 0}\left(w_{12}-w_{i 0}\right)\right] \\
& -0.5\left[\Sigma_{i=1,2}\left(v_{11}+v_{i 0}\right)\left(w_{i 1}-w_{i 0}\right)\right] \\
= & 0.5\left[\Sigma_{i=1,2}\left(w_{11} v_{11}-w_{10} v_{10}-w_{11} v_{i 0}+w_{10} v_{i 1}\right)\right] .
\end{aligned}
$$

and the right-hand side (RHS) of equation (6.2) is:

$$
\begin{aligned}
R H S= & \left(\partial c^{v} / \partial y\right)_{m}\left(y_{1}-y_{0}\right) \\
& +\Sigma_{k=1,2}\left(\partial c^{v} / \partial K_{k}\right)_{m}\left(K_{k 1}-K_{k 0}\right) \\
& +\Sigma_{s=1,2}\left(\partial c^{v} / \partial S_{s}\right)_{m}\left(S_{s 1}-S_{s 0}\right) .
\end{aligned}
$$

Next we expand the second term in equation (6.1) which pertains to non-capital input growth rates:

$$
\begin{aligned}
s_{v m}\left(v_{1}-v_{0}\right) / v_{m} & =\Sigma_{i=1,2}\left[\frac{w_{i m} v_{i m}}{(c / y)_{m} y_{m}} \frac{\left(v_{i 1}-v_{10}\right)}{v_{i m}}\right] \\
& =\Sigma_{i=1,2}\left[\frac{0.5\left(w_{i 1}+w_{i 0}\right)\left(v_{i 1}+v_{i 0}\right)}{(c / y)_{m} y_{m}} \frac{\left(v_{i 1}-v_{i 0}\right)}{0.5\left(v_{i 1}+v_{i 0}\right)}\right] \\
& =0.5\left[\sum_{i=1}^{2}\left(w_{i 1} v_{i 1}-w_{i 0} v_{i 0}-w_{i 1} v_{i 0}+w_{i 0} v_{i 1}\right)\right] /(c / y)_{m} y_{m} .
\end{aligned}
$$

Equations (6.3) (6.4) and (6.5) imply that: 


$$
\begin{aligned}
& s_{v m}\left(v_{1}-v_{0}\right) / v_{m}=\left[\left(\partial c^{\gamma / \partial y}\right)_{m}\left(y_{1}-y_{0}\right)\right. \\
& +\sum_{k=1,2}\left(\partial c^{v} / \partial K_{k}\right)_{m}\left(K_{k I}-K_{k 0}\right) \\
& \left.+\Sigma_{e=1,2}\left(\partial c^{v} / \partial S_{e}\right)_{m}\left(S_{s 1}-S_{s 0}\right)\right] /(c / y)_{m} y_{m} \text {. }
\end{aligned}
$$

Using this result, equation (6.1) now becomes:

$$
\begin{aligned}
\operatorname{TFPG}(0,1)= & \left(\left(y_{1}-y_{0}\right) / y_{m}\right)\left[1-\frac{1}{(c / y)_{m} y_{m}}\left(\partial c^{v} / \partial y\right)_{m} y_{m}\right] \\
& -\frac{1}{(c / y)_{m} Y_{m}}\left[\Sigma_{k=1,2}\left[\omega_{k m}+\left(\partial c^{v} / \partial K_{k}\right)_{m}\right] K_{k m}\left(\frac{K_{k 1}-K_{k 0}}{K_{k m}}\right)\right. \\
& \left.+\Sigma_{e=1,2}\left(\partial c^{v} / \partial S_{s}\right)_{m} S_{s m}\left(\frac{S_{s i}-S_{s 0}}{S_{e m}}\right)\right] .
\end{aligned}
$$

In the long-run equilibrium, $\left(\partial c^{v} / \partial K_{k}\right)_{m}=-w_{k m}, k=1,2$. Therefore.

$$
\begin{aligned}
& \operatorname{TFPG}(0,1)=\left(\left(y_{1}-y_{0}\right) / y_{m}\right)\left[1-\frac{1}{(c / y)_{m}}\left(\partial c^{\nu / \partial y}\right)_{m}\right] \\
& -\frac{1}{(c / y)_{m} y_{m}}\left[\Sigma g=1,2\left(\partial c^{v} / \partial S_{\rho}\right)_{m}\left(S_{e 1}-S_{m o}\right)\right] \text {. }
\end{aligned}
$$

Equation (6.8) is our decomposed TFP growth rate which is to be determined for the Canadian and Japanese industries. The decomposition shows that total factor productivity growth consists of two parts. The first is the scale effect. If returns to scale are constant, then there is no scale effect on productivity growth. that is. the term inside the square brackets is zero [see Appendix to Chapter 6 for the proof]. The second part relates to the spillover effect. There are two spillover effects; one domestic and one international.

Tables 6.1 -6.10 show the average annual TFP growth rales and decomposition for the ten Canadian and Japanese industries under study. The TFP growth rates we obtained are generally close to the Bernstein (1994) findings for Canada and to those 
found in Denny, Bernstein, Fuss, Nakamura and Waverman (1992) for Canada and Japan. Consider first the chemical products industry. In Table 6.1, three components (shown as columns) to total factor productivity growth (TFPG) are identified: the scale effect, domestic spillover and international spillover effects. The TFPG rate is the sum of these three components. The entire sample period (1964 - 1986) and four subperiods (1964 1969. $1970-1974,1975-1980$ and 1981 - 1986) are distinguished as rows in the tables.

Over the period of $1964-1986$. TFPG rate is positive in the chemical products industry of both Canada and Japan. The average annual productivity growth rate is $\mathbf{0 . 8 1}$ percent in Canada, while it is $\mathbf{2 . 0 3}$ percent in Japan. However, productivity growth declines in Canada all the way through to 1986 and in Japan until the early 1980 s before it regains some ground. In both countries, the international spillover effect is zero, since there are no spillovers across the borders, and the scale effect dominates the increase in TFPG. The dominance of the scale effect on TFPG of the Canadian chemical products industry is also found in Bemstein (1994). In Canada, the domestic spillover effect is quite negligible. In Japan, domestic spillovers play an interesting role. Spillovers from within the country exert a negative impact on TFPG of the Japanese industry before the 1980s. These negative externalities result when spillovers directly increase average variable cost. TFPG picks up in the early 1980s, as the domestic spillover effect on TFPG turns to an average annual rate of 1.69 percent. Clearly, TFPG in Japan is closely related to domestic spillovers.

In the electrical products industry, shown in Table 6.2, productivity growth rate is higher in Canada than in Japan. The Japanese industry actually suffers productivity 
Table 6.1

\title{
Docomposition of Average Annual TFP Growth Rates in the Chemical Products Industry (\%)
}

Period

TFPG

Scale

Domestic

Spillover

\author{
International \\ Spillover
}

Rate

\section{Canada}

$\begin{array}{llll}1964-1968 & 1.148 & 1.148 & \\ 1969-1974 & 0.885 & 0.885 & \\ 1975-1980 & 0.797 & 0.797 & \\ 1981-1986 & 0.489 & 0.492 & -0.003 \\ & & & \\ 1964-1986 & 0.816 & 0.817 & -0.001\end{array}$

Japan

$\begin{array}{rrrr}1964-1968 & 3.581 & 3.829 & -0.247 \\ 1969-1974 & 2.522 & 3.110 & -0.587 \\ 1975-1980 & 0.712 & 1.410 & -0.698 \\ 1981-1986 & 1.580 & -0.118 & 1.699 \\ & & & \\ 1964-1986 & 2.034 & 1.981 & 0.053\end{array}$


Table 6.2

\section{Docomposition of Average Annual TFP Growth Rates in the Electrical Products Industry (\%)}

Period

TFPG

Rate

\section{Canada}

1964-1968

0.347

1969-1974

0.153

1975-1980

$1981-1986$

$1964-1986$

0.539

0.310

1.313

Scale

Domestic

Spillover
International

Spillover

\section{Japan}

1964-1968

0.228

$-0.196$

0.425

1969-1974

0.225

$-0.584$

0.809

1975-1980

$-0.807$

$-1.255$

0.447

1981-1986

$-0.372$

$-1.886$

1.514

1964-1986

$-0.199$

.1 .015

0.815 
losses on average. For both countries the scale effect is zero, as there are constant returns to scale in this industry. During the sample period. productivity grows at an average annual rate of 0.54 percent in Canada. While the domestic spillover effect is positive, the spillover from Japan exerts a negative effect on Canadian TFPG. However, the stronger domestic spillover effect ensures TFP gains in Canada. In Bernstein (1994), international spillovers from the U.S. account for over 80 percent of the TFP gains in the Canadian electrical products industry. Bernstein also finds that spillovers from the U.S. generally increase Canadian R \& D capital. This increase causes the domestic spillover pool to rise and hence leads to productivity gains. This latter effect is captured in our study and is reflected through domestic spillovers, which outweighs the effect from Japan.

In Japan the opposite is true. We observe a negative effect from domestic spillovers and a positive effect generated by spillovers from Canada. However, the international spillover effect is relatively smaller, especially from 1975 to 1986 . As a result, the Japanese industry experiences productivity losses of 0.20 percent.

Table 6.3 presents TFPG rates for the food and beverage industry. We see that the scale effect exists only in the Japanese industry and it is the major contributor to productivity gains. There are effects from both spillovers in both countries. In each country, domestic spillovers contribute to productivity gains, while international spillovers do the opposite. In Canada, the major contributor is the domestic spillover. In Bernstein (1994), the U.S. spillover is the main driving force to TFPG in the Canadian food and beverage industry. As for electrical products, the U.S. spillover increases the Canadian domestic spillover pool which, in turn, leads to productivity gains. The average annual 
Table 6.3

\section{Docomposition of Average Annunl TFP Growth Rates in the Food and Beverage Industry (\%)}

Period

TFPG

Rate

\section{Canada}

$\begin{array}{ll}1964-1968 & 0.270 \\ 1969-1974 & 0.156 \\ 1975-1980 & -0.158 \\ 1981-1986 & 0.652\end{array}$

1964-1986

0.228
International Spillover Spillover
Scale

Domestic

1964-1968

1.040

1.189

0.021

$-0.169$

1969-1974

0.529

0.669

0.049

$-0.188$

1975-1980

0.853

0.848

0.132

$-0.126$

1981-1986

0.892

0.701

0.430

$-0.239$

1964-1986

0.819

0.837

0.164

$-0.181$ 
productivity increase is 0.22 percent in Canada and in Japan it is 0.81 percent.

The average annual TFPG rates in the fabricated metals industry are presented in Table 6.4. It is interesting to note that, in Canada. the scale effect accounts for a large portion of TFPG from 1964 to 1974. From 1975 to 1986, the domestic spillover effect is the main contributor. During the entire sample period. TFP grows at an average annual rate of 0.84 percent. While the scale effect accounts for $\mathbf{5 6}$ percent of the increase, the domestic spillover effect is responsible for the rest. In Bernstein (1994), productivity growth results from the combined effects of scale and international spillovers. As it does for the electrical products and food and beverage industries, the U.S. spillover increases the Canadian domestic knowledge base which contributes to productivity gains. Productivity growth in Canada slows down in the 1970s and picks up in the 1980k.

In Japan productivity growth is very steady, increasing all the way through to 1986. On average, the Japanese fabricated metals industry experiences an annual increase of 3.15 percent which is almost four times of that in the corresponding Canadian industry. The gain is generated from increasing returns to scale and the spillovers from domestic sources. International spillovers from Canada also affect TFPG in Japan, but the effect is not as strong as that of domestic spillovers.

In the non-electrical machinery industry, foreign spillovers from Japan do not exist in Canada. Table 6.5 shows that in Canada TFPG declines on average over the sample period. We observe productivity losses from the middle of the 1960s through to the end of the 1970s. The decline in productivity is accounted for mainly by decreasing returns to scale in this industry. Domestic spillovers are contributive to productivity gains, but 
Table 6.4

\section{Docomposition of Average Annunl TPP Growth Rates in the Fabricated Metals Industry (\%)}

Period

TFPG

Rate

\section{Conadn}

1964-1968

1.163

0.940

0.243

1.057

1981-1986

1964-1986

0.837

0.467

$\mathbf{0 . 3 7 0}$
Domestic International

Spillover Spillover

Jopan

1964-1968

1.820

1.987

$-0.008$

$-0.158$

1969-1974

1.867

2.303

0.058

$-0.494$

1975-1980

3.404

2.002

1.586

$-0.185$

1981-1986

5.321

3.620

1.945

$-0.244$

1964-1986

3.159

2.238

1.195

$-0.275$ 
Table 6.5

\section{Docomposition of Average Annual TFP Growth Rates}

in the Non-electrical Machinery Industry (\%)

Period

TFPG

Rate
Scale

Domestic

Spillover
International

Spillover

\section{Canada}

$\begin{array}{llll}1964-1968 & -0.543 & -0.570 & 0.026 \\ 1969-1974 & -0.414 & -0.471 & 0.057 \\ 1975-1980 & -0.211 & -0.258 & 0.047 \\ 1981-1986 & 0.663 & 0.188 & 0.475 \\ & & & \\ 1964-1986 & -0.108 & -0.265 & 0.157\end{array}$

Japan

$\begin{array}{lllll}1964-1968 & 1.267 & 1.243 & 0.019 & 0.004 \\ 1969-1974 & 1.168 & 1.099 & 0.060 & 0.008 \\ 1975-1980 & 0.677 & 0.480 & 0.188 & 0.008 \\ 1981-1986 & 0.955 & 0.404 & 0.543 & 0.008 \\ & & & & \\ 1964-1986 & 1.006 & 0.787 & 0.211 & 0.007\end{array}$


the effect is smaller compared to the scale effect. Bernstein (1994) finds that TFPG of the Canadian non-electrical machinery industry is mainly the result of U.S. spillovers. Bernstein also finds that spillovers from the U.S. generally reduce Canadian production cost and lead to productivity gains. This effect is captured in our study and is reflected through changes in output levels, which outweighs the domestic spillover effect and the effect from Japan to be the main contributor to productivity losses in Canada. Productivity regains its momentum in the 1980s, when the domestic spillover effect becomes stronger than the scale effect. There is a 0.66 percent average annual increase in TFPG between 1981 and 1986, but an overall decrease of 0.11 percent over the entire sample period.

Productivity gains over 1 percent on average annually in the Japanese nonelectrical machinery industry. The scale effect. domestic and foreign spillover effects all contribute to the gains. Domestic spillovers account for 21 percent, foreign spillovers from Canada for 1 percent and the scale effect for 78 pencent of the total increase. Note that TFPG rate declines from the 1960s until the beginning of the 1980 s when it bounces back in Japan.

Table 6.6 shows the TFPG rates in the Canadian and Japanese non-metallic mineral products industry. In Canada, the average annual growth rate is 1.08 percent. Domestic spillovers contribute about 50 percent to the increase in the Canadian productivity. The remaining $\mathbf{5 0}$ percent is the result of increasing returns to scale. In Bemstein (1994) TFPG is generally accounted for by spillovers from the U.S. The U.S. spillover leads to an enlarged pool of Canadian domestic spillovers and causes Canadian 
Table 6.6

Docomposition of Average Annual TFP Growth Rates

in the Non-metallic Mineral Products Industry (\%)

Period

TFPG

Rate
Scale

Domestic

Spillover
International

Spillover

Conada

$\begin{array}{rrrr}1964-1968 & 1.145 & 1.116 & 0.029 \\ 1969-1974 & 1.295 & 1.199 & 0.096 \\ 1975-1980 & 0.099 & -0.065 & 0.165 \\ 1981-1986 & 1.827 & 0.171 & 1.655 \\ & & & \\ 1964-1986 & 1.089 & 0.583 & 0.506\end{array}$

Japan

$1964-1968$

5.504

5.665

0.103

$-0.265$

1969-1974

4.921

5.061

0.209

$-0.348$

1975-1980

$-0.838$

$-1.200$

0.631

$-0.269$

1981-1986

1.406

$-3.276$

5.357

$-0.673$

1964-1986

2.628

1.384

1.639

$-0.394$ 
production cost to decrease and thereby TFP gains.

The average annual growth rate in Japan is over two times higher than that in Canada: the rate is $\mathbf{2 . 6 2}$ percent for Japan. The international spillover effect from Canada is negative but small. Domestic spillovers account for about 60 percent of Japanese TFPG, while the effects of scale and international spillovers explain the rest. Notice that, in the subperiods of $1964-1968$ and $1969-1974$, TFPG rates are quite high in this Japanese industry duc to cutput growth associated with scale economies. However, from 1975 to 1986, the domestic spillover is the main contributor so that TFPG in that period is positive. despite the negative scale effect

In the paper and allied products industry, there are constant returns to scale in both countries. In Canada, there is no intemational spillover effect. Thus, the domestic spillover effect is the sole contributor to the productivity growth of this industry. In Bernstein (1994) the international spillover effect from the U.S. is the largest contributor to the productivity gains of the Canadian paper and allied products industry. Clearly, an increased Canadian domestic spillover pool results from the U.S. spillovers, so that the domestic spillover effect becomes the important contributor to TFPG in our study. Such effect is positive and, though the effect is small, TFPG rate is higher in Canada than in Japan for this industry. The respective average annual growth rates are 0.09 percent and 0.03 percent. Note that, in Japan, though foreign spillovers from Canada docrease productivity, the domestic spillover effect is relatively stronger.

Petroleum products industry represents a case where TFPG is negative in both countries. especially in Japan. The TFP decrease in Canada is mainly the result of the 
Table 6.7

\section{Docompodtion of Avernue Anunad THP Growth Roles In the Paper and Alled Products Induatry $\left(\%_{0}\right)$}

Period

TFPG

Rate

\section{Canoda}

1964-1968

1969-1974

$1975-1980$

1981-1986

1964-1986

0.098

Scale

Domestic

Spillover
Intemational

Spillover

Japan

1964-1968

0.322

0.084

0.237

1969-1974

$-0.712$

0.242

$-0.954$

1975-1980

$-0.261$

0.540

$-0.801$

1981-1986

0.847

1.044

$-0.197$

1964-1986

0.037

0.495

$-0.457$ 
Table 6.8

\section{Docomposition of Average Annual TFP Growth Rates}

in the Petroleum Products Industry (\%)

\begin{tabular}{|c|c|c|c|c|}
\hline Period & TFPG & Scale & Domestic & International \\
\hline & Rate & & Spillover & Spillover \\
\hline
\end{tabular}

\section{Canada}

$\begin{array}{llll}1964-1968 & -0.622 & -0.695 & 0.073 \\ 1969-1974 & -1.010 & -1.105 & 0.094 \\ 1975-1980 & -0.214 & -0.308 & 0.094 \\ 1981-1986 & 1.010 & 0.536 & 0.474 \\ 1964-1986 & -0.191 & -0.380 & 0.188\end{array}$

Jopan

$\begin{array}{lllll}1964-1968 & -4.722 & -4.711 & -0.021 & 0.010 \\ 1969-1974 & -3.487 & -3.426 & -0.056 & -0.005 \\ 1975-1980 & -1.741 & -1.666 & -0.123 & 0.042 \\ 1981-1986 & -0.239 & -0.105 & -0.202 & 0.068 \\ 1964-1986 & -2.453 & -2.379 & -0.104 & 0.300\end{array}$


scale effect. As for the non-electrical machinery industry. Bernstein (1994) finds that the U.S. spillover causes reductions in Canadian production cost which is reflected through changes in output levels, so that the scale effect in our study is more responsible than other effects for productivity losses in Canada. In Canada domestic spillovers lead to productivity gains, but the effect is not as strong as the scale effect. However, as the domestic spillover effect becomes proportionally more important in the 1980s. productivity growth rate turns to a positive 1.01 percent, though the growth rate for the entire sample period is a negative 0.19 percent.

In Japan spillovers from Canada exert a positive effect on TFPG, but it is quite small compared to the effect of domestic externalities which is negative. In addition, the scale effect is also negative and dominating so that the average annual growih rate is a negative $\mathbf{2 . 4 5}$ percent. It should be noted that, the productivity decline in this Japanese industry is greater in the period 1964 - 1974, compared to the peri.d 1975 - 1986.

In Table 6.9, average annual TFPG rates in the Canadian and Japanese primary metals industry are not significantly different. Productivity grows at an average annual rate of 1.34 percent in Canada and $\mathbf{1 . 3 8}$ percent in Japan over the sample period. In both countries, the scale effect dominates the increase in TFPG. In addition, while the domestic effect is negative, the intemational effect is generally positive. In Bernstein (1994), the scale effect is combined with the international spillover effect from the U.S., which generates productivity increases in Canada. As for other industries in this study, the U.S. spillover reduces Canadian average variable cost which is reflected in output changes: he effect of this contributes significantly to Canadian TFPG. 
Table 6.9

\section{Docomposition of Average Annual TFP Growth Rates in the Primary Metals Industry (\%)}

Period

\section{Canoda}

1964-1968

1969-1974

1975-1980

1981-1986

$1964-1986$

1.277

1.345
TFPG

Rate

Scale

3.024

1.584

$-0.059$

1.548

1.459

$-0.403$

0.289

Spillover Spillover

\section{Japan}

1964-1968

1.654

2.492

$-0.089$

$-0.747$

1969-1974

1.395

2.206

$-0.247$

$-0.562$

1975-1980

$-0.479$

$-0.221$

$-0.483$

0.225

1981-1986

3.031

0.008

$-0.163$

3.186

1964-1986

1.389

1.061

$-0.253$

0.580 
However, there are differences between the two countries when it comes to the subperiods. In the Canadian primary metals industry, the average annual growth rate ranges from a negative 0.03 percent to 2.88 percent. The rate is the highest from 1964 to 1968. However, it decreases till the beginning of the 1980s when it turns up again. In Japan the range of growth is between a negative 0.47 percent and 3.03 percent. Productivity declines from 1964 till the end of the 1970s. In the 1980s the growth rate surpasses the previous record to be the highest rate of all subperiods.

The last industry to be considered is transportation equipment. The TFPG rates for this industry are reported in Table 6.10. In Canada. TFPG rate is quite small at an annual average of around 0.02 percent. Productivity growth is negative from 1964 to 1974, but then it tums positive and increases. The gain in productivity is clearly due to the effect of domestic R \& D spillovers, as the scale effect is generally negative and there is no international spillover effect from Japan. Bernstein (1994) finds that the international spillover effect accounts for a major portion of TFPG in this Canadian industry. This is one more industry where the U.S. spillover increases the Canadian domestic spillover pool which outweighs the effect of spillovers from Japan to be the major contributor to productivity gains.

In the Japanese transportation equipment industry, the average annual TFPG rate is 0.30 percent. About 90 percent of the growth results from domestic spillovers and 10 percent is attributable to international externalities. There are constant returns to scale in this industry. It is interesting to note that productivity declines all the way until the 1980s when it turns up quite significantly. Actually, the average annual gain over the 
Table 6.10

\section{Docomposition of Average Annual TFP Growth Rates in the Transportation Equipment Industry (\%)}

Period TFPG

Rate

\section{Canada}

$\begin{array}{llll}1964-1968 & -0.536 & -0.702 & 0.166 \\ 1969-1974 & -0.287 & -0.475 & 0.188 \\ 1975-1980 & 0.228 & 0.043 & 0.184 \\ 1981-1986 & 0.573 & -0.040 & 0.613\end{array}$

1964-1986

0.017

$-0.276$

0.293

\section{Japan}

$\begin{array}{llll}1964-1968 & -0.141 & -0.142 & 0.001 \\ 1969-1974 & -0.384 & -0.398 & 0.014 \\ 1975-1980 & -0.408 & -0.435 & 0.027 \\ 1981-1986 & 2.091 & 2.016 & 0.074 \\ & & & \\ 1964-1986 & 0.308 & 0.277 & 0.030\end{array}$


whole sample period is due only to the productivity increase in the $1980 \mathrm{k}$.

\subsection{Social Rates of Return to R \& D}

Due to the nature of $R \& D$ capital, some form of spillovers are inevitably associated with $R$ \& $D$ investment. The returns to $R \& D$ are not completely appropriated by the $R \& D$ investor. Therefore, a wedge is created between the private and social rates of return. The private return is the return from $R \& D$ performance. The social return is the retum from the use of $R \& D$; hence it is inclusive of $R \& D$ spillovers.

The social rate of return to $R \& D$ capital is measured as the sum of the private rate of retum and the rate of retum associated with intranational and international spillovers. Consider firs' the private rate of return to $\mathbf{R} \& \mathbf{D}$ capital for each industry in each country. The private rate of retum is the marginal cost reduction per dollar of $R \&$ D capital expansion. It is equal to the rental rate divided by the acquisition price of $\mathbf{R}$ \& D capital, and obtained from the first order condition given by equation (3.7). The private rate is the before-tax gross of depreciation rate of return. The private rate of return in period $t$ for industry $f$ in country $j$ is defined as follows:

$$
p_{r t}^{f j}=-\left(\partial c_{t}^{v f j} / \partial K_{r t}^{f j}\right) / q_{r t}^{f j}
$$

where $q_{r}$ is the acquisition price of $\mathbf{R} \& \mathbf{D}$ capital.

The rate of retum to $R$ \& associated with spillovers can be calculated by considering jointly the Canadian and Japanese cost of production. Joint cost is defined as: 


$$
a_{t}=\Sigma_{j=1}^{z} \Sigma_{i=1}^{10}\left(c^{v i j}\left(w_{t}^{1 j}, y_{t}^{i j}, K_{t}^{1 j}, s_{t}^{i j}\right)+\omega_{k t}^{1 j} K_{t}^{i j}\right)
$$

where the superscript $i$ denotes the industry and $j$ denotes the country.

Suppose that equation (6.10) is to be evaluated at the equilibrium input-output ratios for each industry and country. Joint cost is not minimized at the equilibrium due to the existence of intranational and intemational spillovers. The reason is that, since $\mathbf{R}$ \& D capital stock is jointly used by all industries in both countries, additional profits are generated as $R$ \& $D$ spillovers are internalized. The additional profit is the reduction in joint cost resulting from two sources; domestic and international spillovers.

Using equation (3.8), the joint domestic cost reduction per dollar of $R \&$ D capital at equilibrium in period $t$ from an increase in the $f$ th industry's $R$ \& D capital in the $j$ th country is:

$$
\begin{gathered}
d_{r t}^{f j}=\Sigma_{i=1,1 * t}^{10} \Sigma_{h=1}^{2}\left(K_{h t} / y_{t}\right)^{1 y_{\eta}} \eta_{h 1}^{11} w_{t}^{i j} y_{t}^{1 j} / q_{r t}^{t j} \\
j=1,2 .
\end{gathered}
$$

The reduction in joint cost that results from a dollar increase in the $R \& D$ capital of the fth industry in the jth country is expressed as:

$$
\begin{gathered}
i_{r t}^{f j}=\Sigma_{h=1}^{2}\left(k_{h t} / y_{t}\right)^{f k_{\eta}} \eta_{h 2}^{f k} w_{t}^{f k} y_{t}^{f k} / q_{r t}^{f j} \\
j \neq k, \quad j, k=1,2 .
\end{gathered}
$$

Equations (6.11) and (6.12) define the domestic and foreign wedges between the social and private rates of return per dollar of $R \& D$ capital evaluated at equilibrium that arises from the $R \& D$ capital of the fth industry in the $j$ th country.

Thus, the social rate of return to $R$ \& $D$ capital in industry $f$ of country $j$ is: 


$$
\gamma_{r t}^{f j}=p_{x t}^{f y}+d_{x t}^{f J}+i_{x t}^{f f}
$$

which consists of three components: the private rate of return, the retum from domestic spillovers and the return from international spillovers.

The rates of retum to $R$ \& $D$ capital in the Canadian and Japanese industries are presented in Tables 6.11 and 6.12 respectively. Note that the rates of retum reported in these tables are comparable since they are purchasing power parity returns. The Japanese data is purchasing power parity adjusted to the Canadian data by the method described in Section 3 of Chapter 4.

The first column in both tables represents the private rate of return. Since the private rate is defined as the rental rate deflated by the $R$ \& $D$ capital purchase price and. since the same inflation rate is assumed across industries but different for each country, the private rates of retum are the same across industries in Canada or Japan. Moreover. the private retum is very similar in both countries; in Canada this is 17.2 percent and in Japan 17.4 percent. With a 10 percent depreciation rate in both countries, a corporate tax rate of 46 percent in Canada and 37 perient in Japan, the net rate of return on a purchasing power basis is approximately 3.8 percent in Canada and 4.6 percent in Japan.

The retums from domestic and international spillovers are shown in the second and third columns of Tables 6.11 - 6.12. In Canada, the domestic spillover related retums are quite high in every industry, compared to the returns accruing from international spillovers. In the chemical products industry, there are no retums resulting from intemational spillovers. In all other industries domestic spillover returns substantially exceed those that are internationally associated. In the food and beverage, fabricated 
Toble 6.11

Social Rates of Return to $\mathrm{R}$ \& $\mathrm{D}$ in Canadian Industries (mean percent)

Industry

Chemicl Products

Electrical Products

Food \& Beverage

Fabricated Metals

Non-electrical Machinery

Non-metallic Mineral Products

Paper \& Allied Products

Petroleum Products

Primary Metals

Transportation Equipment
Privale Rate of Return
Spillover Return

Domeatic
Intern.

Social Rate

of Return
17.200

17.200

17.200

17.200

17.200

17.200

17.200

17.200

17.200

17.200
134.503

71.531

65.739

118.168

125.377

123.169

128.061

166.976

164.001

1.595

19.495

23.134

$-4.355$

$-2.548$

1.497

$-23.994$

57.932

22.703
117.424
206.878

151.703

111.865

78.583

132.820

144.075

116.375

203.193

182.797

154.119 
Table 6.12

Social Rates of Return to R \& D in Japanese Industries (mean percent)

Industry

Chemicl Products

Electrical Products

Food \& Beverage

Fabricated Metals

Non-electrical Machinery

Non-metallic Mineral Products

Paper \& Allied Products

Petroleum Products

Primary Metals

Transportation Equipment
Private Rate of Returm

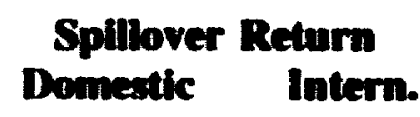

Social Rate

of Return
66.297

56.538

26.318

17.360

15.989

$-7.031$

63.608

17.360

46.248

53.804

71.164

17.360

30.466

47.826

72.968

17.360

55.607

35.448

52.808

17.360

40.150

0.778

58.289

17.360

42.042

59.402 
metals and non-metallic mineral products industries, the international spillover related portion of the return is negative. The negative return is possible when spillovers give rise to direct cost increases in production. However, the negative retum related to international spillovers is small relative to the domestic retum, especially in food and beverage and fabricated metals industries, so that the combined spillover returns for these industries are positive.

In Japan, the spillover returns are essentially domestic-based. In seven industries, internationally-based returns are zero. Among the three industries who are senders of spillovers to Canada. we observe very small (either positive or negative) rates of return related to international spillovers.

The last column shows the social rates of retum for each industry in each country. The social rate of retum is the total of the three components summed up horizontally for each industry. These results suggest that the social rate of return can exceed the private rate quite substantially. In Canada, the social returns can be as high as tweive times the private rate. The lowest social rate is observed in the food and beverage industry where it is four and half times the private rate. The order of ranking from highest to lowest is: petroleum products, paper and allied products, primary metals, transportation equipment, chemical products, non-electrical machinery, fabricated metals, non-metallic mineral products, electrical products and food and beverage. The social rates of retum in the Canadian industries are in the range of 78 percent to 206 percent.

The large differential between the private and social rates of return is found in many studies for different countries. Bernstein (1983) finds that at the firm level for 
Canada, the social return is from 20 percent to 115 percent greater than the private return. In Bernstein (1989) dealing with industry data. the social rate of return is two to four times the private retum on a sample of nine Canadian industries. Bernstein and Nadiri (1988, 1989) also find much higher social than private rates of retum for selected U.S. firms and industries.

In Japan. the social rate of retum is one and half to over four times greater than the private retum. The ranking from highest to lowest is: paper and allied products, nonelectrical machinery, chemical products, fabricated metals, iransportation equipment. primary metals, electrical products, petroleum products, non-metallic mineral products. and food and beverage. The social rates of retum in the Japanese industries range from 26 percent to 73 percent. Clearly, there are high social retums resulting from $R \& D$ capital investment and a major portion of it is derived from domestic spillovers. These returns are new to the literature, but they are also consistent with the esults for Canada and the IIS.

High rates of social retum imply that $\mathbf{R} \& \mathbf{D}$ capital is substantially underinvested. especially in Canada. Such underinvestment is surely not attributable to substantial intemational retums from foreign industries.

\subsection{Summary of the Findings on TFPG and Social Retums}

A number of findings can be drawn from the study. In general, spillovers contribute positively to total factor productivity growth of the Canadian and Japancie industries. In addition, in both countries TFP growth is essentially the effect of domestic 
spillovers. However, for Canada, increases in R \& D capital from U.S. spillovers [see Bernstein (1994)] lead to increases in the Canadian domestic spillover pool. This effect is implicilly captured in this thesis through the Canadian domestic spillover.

The study finds that total factor productivity growth is generally higher in Japan than in Canada. In many cases, the growth rates in Japan are one and one-half to four times higher than the growth rates in the corresponding Canadian industries. This is consistent with the Denny, Fuss. Nakamura and Waverman (1992) findings. The respective Canadian and Japanese average annual TFP growth rates during the period of 1964 -1986 are: 0.81 percent and 2.03 percent for chemical products, 0.53 percent and 0.20 percent for electrical products. 0.22 percent and 0.81 percent for food and beverage, 0.83 percent and 3.15 percent for fabricated metals, -0.11 percent and 1.01 percent for non-electrical machinery, 1.08 percent and 2.62 percent for non-metallic mineral products. 0.09 percent and 0.03 percent for paper and allied products, -0.19 percent and -2.45 percent for petroleum products, 1.34 percent and 1.38 percent for primary metals, 0.02 percent and 0.31 percent for transportation equipment. We also find that productivity growth is generally slow and declining from the middle of the 1960 s to the end of the 1970s. For many industries, productivity regains its momentum in the 1980s. This is consistent with Denny. Bemstein. Fuss, Nakamura and Waverman (1992).

The social rates of retum to $R$ \& D capital in Canada are found to be much higher than those in Japan for every industry. They are at least two to three times greater than the Japanese counterparts. The social rates of retum in the Canadian industries are in the range of 78 percent to 206 percent. The corresponding rates in Japan range from 26 
percent to 73 percent. In both countries, the wedge between social and private retums arises primarily from domestic spillovers in Canada and Japan.

In each country, the social rates of return exceed the private rates hy a substantial margin. The private rales of return are very similar for Canada and Japan, both nominally and in real terms. The before-tax. gross of depreciation private rate is approximately 17 percent, while the after-tax, net of depreciation rate is approximately 4 percent. The rate differential is four and one-half to twelve times in Canada and in Japan it is one and onehalf to four times. The findings are consistemt with Bemstein (1988, 1989) for Canadian industries and with Bernstein and Nadiri (1988, 1989) for U.S. industries. 
APPENDIX

\section{TO CHAPTER 6}


In this appendix we show that the first term inside the square brackets of equation (6.8) is zero in long-run equilibrium when there is constant returns to scale.

The term inside the square brackets is:

(A6.1)

$$
1-\frac{1}{(c / y)_{m}}\left(\frac{\partial c^{v}}{\partial y}\right)_{m}=\left[\frac{\left(\frac{c}{y}\right)+\left(\frac{c}{y}\right)_{0}}{2}-\frac{\left(\frac{\partial c^{v}}{\partial y}\right)+\left(\frac{\partial c^{v}}{\partial y}\right)}{2}\right] \frac{1}{\left[\frac{\left(\frac{c}{y}\right)+\left(\frac{c}{y}\right)_{0}}{2}\right]} .
$$

By definition, the degree of returns to scale $\left(\theta^{-1}\right)$ is:

$$
\theta^{-1}=\left[1-\sum_{k=1}^{2} \frac{\partial c^{v}}{\partial K_{k}} \frac{K_{k}}{c^{v}}\right] / \frac{\partial c^{v}}{\partial y} \frac{y}{c^{v}}
$$

If there are constant returns to scale so $\theta^{-1}=1$, then in each period of time:

$$
\frac{\partial c^{v}}{\partial y}=\left(1-\sum_{k=1}^{2} \frac{\partial c^{v}}{\partial K_{k}} \frac{K_{k}}{c^{v}}\right) \frac{c^{v}}{y}
$$

In equilibium, $\frac{\partial c^{v}}{\partial K_{k}}=-w_{k}, k=1,2$. Hence,

$$
\frac{\partial c^{v}}{\partial y}=\frac{c^{v}}{y}+\sum_{k-1}^{Z} w_{k} \frac{K_{k}}{y}
$$

Since $c=c^{v}+\sum_{k=1}^{2} w_{k} K_{k}$, then

$$
\frac{\partial c^{v}}{\partial y}=\frac{c}{y}
$$

Thus, the right side of (A6.1) is zero. 


\section{REFERENCES}

Bernstein, J.I. (1994), "R \& D Spillovers Between U.S. and Canadian Industries", Forthcoming Canadian Journal of Economics, Papers and Proceedings.

Bernstein. J.I., and P. Mohnen (1991), "Price-cost Margins. Exports and Productivity Growth: with an Application to Canadian Industries", Canadian Joumal of Economics, August, 1991, pp. 638-659.

Denny, M., J.1. Bernstein, M. Fuss, S. Nakamura and L. Waverman (1992), "Productivity in Manufacturing Industries in Canada, Japan and United States 1953-1986: Was the 'Productivity Slowdown' Reversed?", Canadian Journal of Economics, XXV No.3 August, 1992, pp. 584-603.

Denny, M., M. Fuss, and L. Waverman (1981), "The Measurement and Interpretation of Total Factor Productivity in Regulated Industries, with an Application to Canadian Telecommunications", in T. Cowing and R. Stevenson (eds.), Productivity Measurement in Regulated Industries, New York: Academic Press, pp. 179-218. Griliches, Z. (1988). "Productivity Puzzles and R \& D: Another Nonexplanation", Joumal of Economic Perspectives, 2, pp. 9-21.

Griliches. Z. (1979). "Issues in Assessing the Contribution of Research and Development to Productivity Growth", Bell Journal of Economics, 10(1), pp. 92-116.

Mohnen, P. (1990), "Relationship between R \& D and Productivity Growth in Canada and Other Major Industrialized Countries", Centre de recherche sur les politiques économiques. Université du Québec à Montréal. 
Mohnen, P.. M.I. Nadiri and I.R. Prucha (1986), "R \& D. Production Structure and Rates of Return in the U.S., Japanese and German Manufacturing Sectors: A Nonseparable Dynamic Factor Demand Model", European Economic Review (30), pp. 749-771.

Terleckyj, N. (1974), "Effects of R \& D on the Productivity Growth of Industries: An Explanatory Study", National Planning Association, Washington D.C. 


\section{CHAPTER 7 SUMMARY AND CONCLUSION}

In this thesis we investigated the effects of intranational or domestic and international or foreign $\mathbf{R} \& \mathrm{D}$ spillovers on average variable cost of production, factor intensities, productivity growth and social rates of return. The international spillovers linked ten Canadian and Japanese manufacturing industries. These industries include: chemical products, electrical products, food and beverage, fabricated metals, non-electrical machinery, non-metallic mineral products, paper and allied products, petroleum products, prinaary metals and transportation equipment.

The study has resulted in a number of important findings. No significant intemational R \& D spillovers from Japan exist in the Canadian chemical products, fabricated metals, non-electrical machinery, non-metallic mineral products, paper and allied products, petroleum products, primary metals and transportation equipment industries. However, the Canadian food and beverage, electrical products and primary metals industries are users of spillovers originating from Japan. Even in these three industries, the domestic spillover effects dominate the international spillovers from Japan. Intemational spillovers from Canada are found to affect all the Japanese industries except chemical products. In Japan, as for Canada, domestic spillovers dominate their foreign counterparts. These results. along with Bernstein (1994), indicate that foreign spillovers in Canada are dominated by the externalities emanating from the U.S. Moreover, the strong relationship between the U.S. and Canadian $R$ \& $D$ capital stocks suggests that there is a North American technological link to Japan, though this link is not as strong as the domestic links found in Japan. 
International spillovers generally decrease average variable cost. as seven out of ten Japanese industries attain cost-reductions directly from the $R \& D$ expansion in Canada. Direct average variable cost decreases in Japan associated with a 1 percent increase in Canadian R \& D capital are: 0.13 percent for electrical products, 0.04 percent for fabricated metals, 0.001 percent for non-electrical machinery, 0.43 percent for paper and allied products, 0.14 percent for petroleum products, 0.46 percent for primary metals and 0.02 percent for transportation equipment. These elasticity estimates are new to the literature.

Domestic and foreign spillovers generally exert a greater influence on R \& D capital intensity than on other factor intensities. International spillovers from Canada increase $R \& D$ intensity in the Japanese fabricated metals, non-electrical machinery, paper and allied products, petroleum products, primary metals and transportation equipment industries. Increases across industries range from 0.03 percent to 4.80 percent. The decrease in R \& D capital intensity in the electrical products, food and beverage and non-metallic mineral products industries ranges from 0.85 percent to 1.30 percent. Japanese domestic spillovers are a strong complement to own $R$ \& $D$, increasing $R$ \& D capital intensity in every industry. The range is from 0.28 percent to 2.15 percent. Canadian domestic spillovers increase R \& D capital intensity in food and beverage. fabricated metals, non-electrical machinery, non-metallic mineral products, paper and allied products and petroleum products and decrease that in chemical products, electrical products, primary metals and transportation equipment. The increase in R \& D capital intensity varies from 0.01 percent to 2.41 percent and the decrease ranges between 0.01 
percent and 1.74 percent.

With respect to other factor intensities, it is found that spillovers from both sources can either increase or decrease physical capital intensity. In Japan, international spillovers increase physical capital intensity in six industries by between 0.01 percent and 0.37 percent. Domestic spillovers increase the intensity in another set of five industries from 0.05 percent to 0.20 percent. In Canada, physical capital intensity decreases in seven industries ranging from 0.001 percent to 0.15 percent. However, the increases are quite large in the eloctrical products, non-electrical machinery and non-metaltic mineral products industries: the respective increases are 4.21 percent, 1.14 percent and 0.17 percent. Labour and intermediate input intensities always respond in the same way. In Japan. domestic spillovers reduce variable factor intensities in eight industries. In Canada, domestic spillovers result in lower variable factor intensities in four industries. In the other six industries the increases are quite small.

We estimate that returns to scale are the same in five of the ten Canadian and Japanese industries: chemical products, electrical products, non-electrical machinery, paper and allied products and petroleum products industries. The other five industries where returns to scale differs are: food and beverage, fabricated metals, non-metallic mineral products. primary metals and transportation equipment. There are constant returns to scale in the Canadian and Japanese electrical products and paper and allied products. the Canadian food and beverage and the Japanese transportation equipment industries. The Canadian and Japanese chemical products, fabricated metals, non-metallic mineral products, primary metals and the Japanese food and beverage industries are found 
to exhibit increasing returns to scale, while decreasing returns to scale are observed for the Canadian and Japanese non-electrical machinery, petroleum products and the Canadian transportation equipment industries.

The findings pertaining to the TFP decomposition are that intranational and intemational spillovers generally contribute positively to total factor productivity growth of the Canadian and Japanese industries. In Canada, domestic spillovers increase TFP growth in eight industries. In Japan, domestic spillovers increase TFP growth in seven industries, while international spillovers contribute to TFP growth in five industries. In addition, in both countries TFP growth is essentially due to domestic spillovers, since international spillovers do not generally exist in Canada and. in the majority of the Japanese industries, the international spillover impact is weaker than the domestic equivalent. The result for Canada is consistent with Bernstein (1994) where it is found that U.S. R \& D spillovers mainly contribute to TFP growth. The reason is that the U.S. spillovers lead to increases in the Canadian domestic $\mathbf{R} \& \mathbf{D}$ spillover pool. It is this latter effect which is implicitly captured in the TFP growth decomposition of this thesis. Thus, we find that the Canadian domestic spillover effect outweighs the effect of spillovers from Japan as the major contributor to productivity gains.

We find that total factor productivity growth is generally higher in Japan than in Canada. In many cases, they are one-half to four times greater than the Canadian growth rates. The respective Canadian and Japanese average annual TFP growth rates during the period of $1964-1986$ are: 0.81 percent and 2.03 percent for chemical products, 0.53 percent and -0.20 percent for electrical products, 0.22 percent and 0.81 percent for food 
and beverage. 0.83 percent and 3.15 percent for fabricated metals, -0.11 percent and 1.01 percent for non-electrical machinery, 1.08 percent and 2.62 percent for non-metallic mincrals. 0.09 percent and 0.03 percent for paper and allied products, -0.19 percent and -2.45 percent for petroleum products, 1.34 percent and 1.38 percent for primary metals, 0.02 percent and 0.31 percent for transportation equipment. We also find that productivity growth is generally slow and declining from the middle of the 1960 s to the end of the 1970s. For many industries, productivity regains its momentum in the 1980 s.

Social rates of retum to $R \hat{\alpha} D$ are found to exceed private retums quite substantially in both countries. The private rates of retum are very similar for Canada and Japan, both nominally and in real terms. The before-tax, gross of depreciation private rate is around 17 percent, while the after-tax, net of depreciation rate is approximately 4 percent. The social and private rate differential is from four and one-half to twelve times in Canada, and in Japan it is from one and one-half to four times. Moreover, the social rates of return to $R \& D$ capital in Canada are found to be much higher than those in Japan for every industry. They are at least two to three times greater than the Japanese counterparts. The social rates of return in the Canadian industries are in the range of 78 percent to 206 percent. The corresponding rate in Japan ranges from 26 percent to 73 percent. In both countries, the wedge between social and private retums do not arise from international spillovers between Canada and Japan.

The findings from this study have important policy implications for Canada. Since R \& D spillovers from Japan do not generally exist in Canada, there is not much to be said for intemational policy. However, Canadian domestic spillovers contribute to cost 
reductions and total factor productivity gains. Thus, domestic interindustry transfer of technology should be encouraged and facilitated by the government. There are various possible ways to accomplish this. One such choice is to form interindustry technology consortia whereby industries join research and development efforts. so that the individual consortia members benefit from the joint $R \& D$ activities. In this light. the internal barriers to technology diffusion of any form should be eliminated to ensure casier access to new knowledge. There may also be reason for government assistance to $R$ D activities in the form of tax credits and allowances. However, these instruments should not be targeted to a particular industry, but to $R \& D$ activities in general. In addition. the costs of the these subsidies should be considered along with the benefits. The latter should be inclusive of all spillovers. 

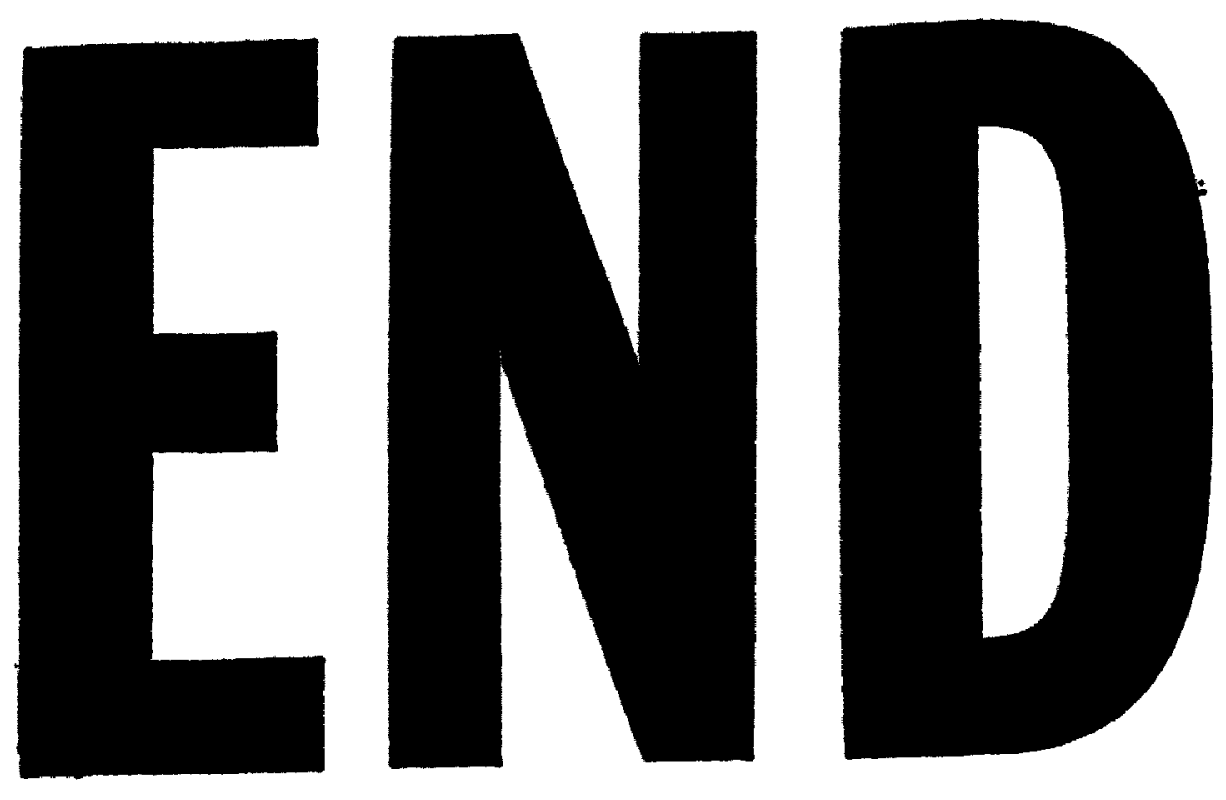

$:$
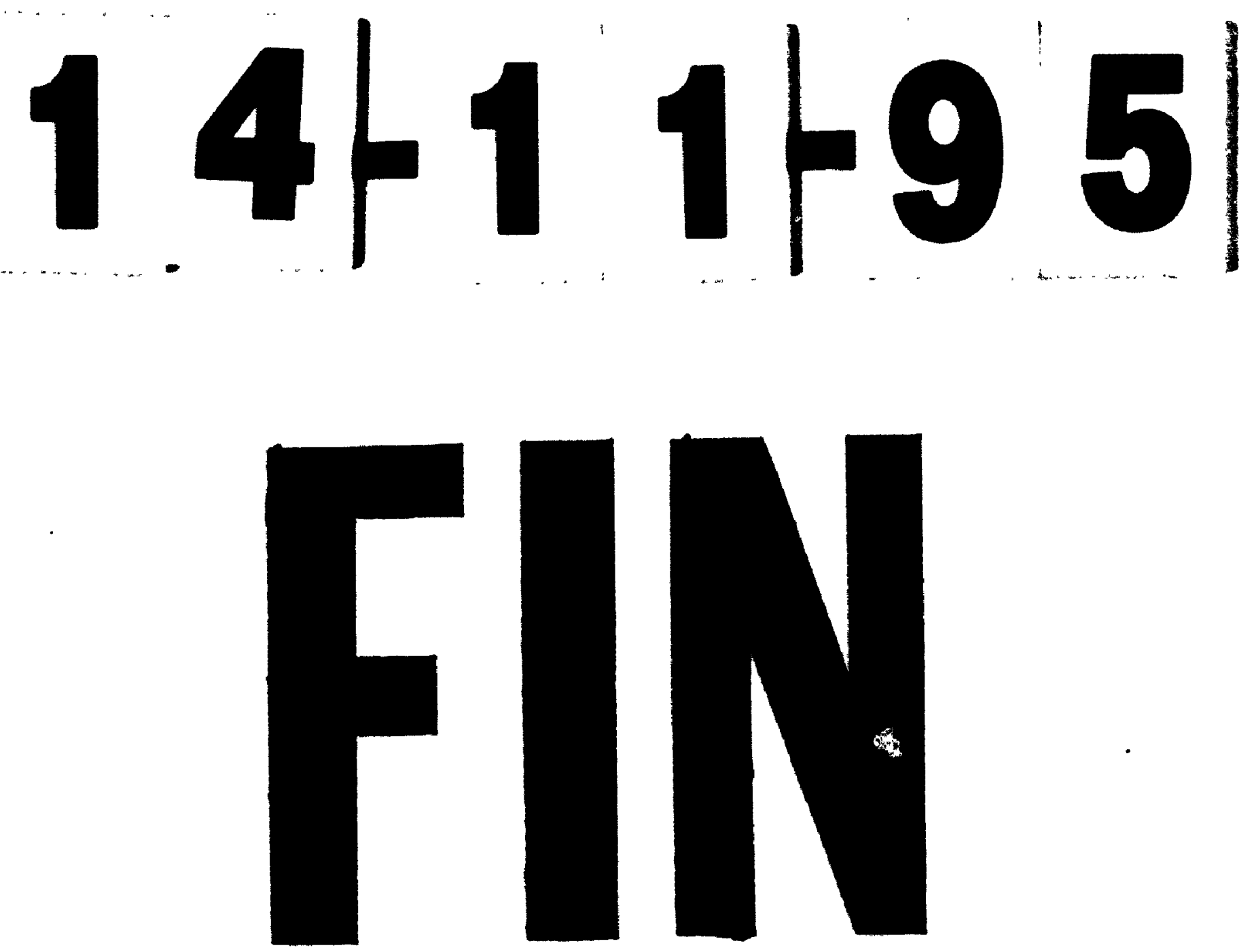